\title{
Estudo in vitro do efeito de três diferentes agentes clareadores sobre a dureza e rugosidade do esmalte dentário bovino
}

\section{Heraldo Riehl}

Tese apresentada à Faculdade de Odontologia de Bauru, da Universidade de São Paulo, como parte dos requisitos para a obtenção do título de Doutor em Odontologia, área de Dentística, opção Materiais Dentários.

EDIÇÃO REVISADA 


\section{Estudo in vitro do efeito de três diferentes agentes clareadores sobre a dureza e rugosidade do esmalte dentário bovino}

\section{Heraldo Riehl}

Tese apresentada à Faculdade de Odontologia de Bauru, da Universidade de São Paulo, como parte dos requisitos para a obtenção do título de Doutor em Odontologia, área de Dentística, opção Materiais Dentários.

Orientador: Prof. Dr. César Antunes de Freitas 


\section{Ficha técnica}

Heraldo Riehl: concepção original, execução, redação e digitação.

César Antunes de Freitas: orientação geral, revisão final.

Maristela Petenuci Ferrari Fabrini: revisão, formatação e impressão.

Sérgio Augusto Riehl e Andréa Brandini Dias Batagliotti: revisão final do vernáculo.

Cybelle de Assumpção Fontes e Valéria Cristina Trindade Ferraz: normatização técnica.

Marcus Thame: cópias, encadernação em espiral.

Encadernações Manzano: encadernação em capa dura.

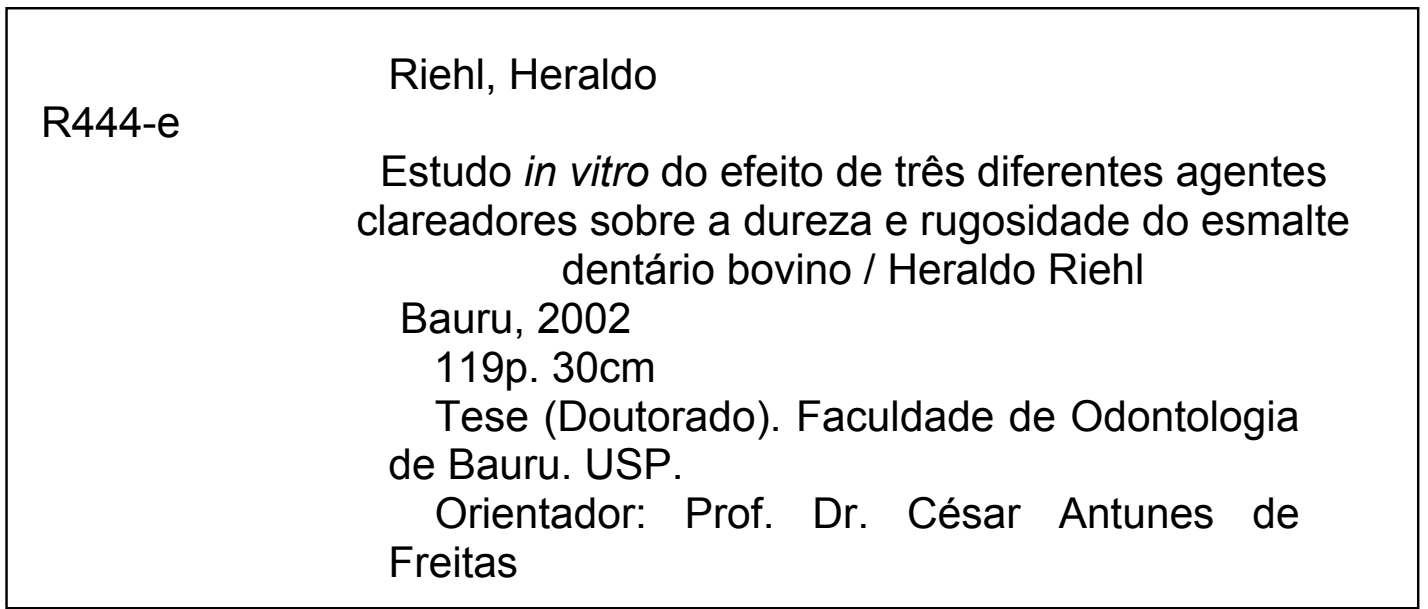

Autorizo, exclusivamente para fins acadêmicos e científicos, a reprodução total ou parcial desta dissertação/tese, por processos fotocopiadores e outros meios eletrônicos.

Assinatura: 
À Faculdade de Odontologia de Araraquara UNNESP, os meus agradecimentos pelas oportunidades oferecidas, para que houvesse um despertar cientifico $e$ crítico durante meu curso de graduação.

À Faculdade de Odontologia de Bauru, na pessoa de seu DD. Diretor Prof. Dr. Aymar Pavarini, pela recepção amigável a todos os colegas dos cursos de Pós-Graduação, o meu sincero agradecimento.

Ao Presidente da Pós-Graduação Prof. Dr. Luiz Fernando Pegoraro.

Ao CNPP, pelo apoio financeiro proporcionado, fundamental para a realização deste trabalho, meu reconhecimento e admiração. 


\section{Dedico esse trabalho}

A Deus, Criador de todos nós. Pela sua grandiosidade e magnanimidade em intervir em nossas vidas, mesmo sabendo que a Vós muitos recorrem apenas nas horas difíceis.

Ao meu pai, Sérgio, por me fazer enxergar em seus netos o mesmo que um dia enxergou em mim. Desta maneira, fica fácil compreender, agradecer e louvar a amabilíssima missão de ser pai. Companheiro inseparável nos momentos difíceis, serei extremamente feliz se algum dia poder fazer para meus filhos o que fez por mim quando eu mais precisei.

À minha mãe, Jacira, luz constante em minha vida com suas lembranças e ensinamentos, fazendo-me entender que nesta vida, basicamente, tudo se resume a três coisas: amar ao próximo, saber perdoar e entregar-se a Deus.

À minha irmã, Luciane, obrigado pelo ouvido amigo (sei que a recíproca é verdadeira), pelo grande incentivo nas horas difíceis, por sempre insistir no "nunca desista..." e por ser uma mulher perseverante.

Ao Dr. Marcelo Garcia Leal, médico cardiologista da cidade de Ribeirão Preto - SP, que com a precisão de seu diagnóstico, interviu com serenidade, fé e amor à sua profissão, durante o meu bem sucedido tratamento emergencial e preparo précirúrgico, transmitindo-me segurança e uma postura de clínico/pesquisador admirável.

Ao Dr. José Henrique de Andrade Vila, cardiologista, cirurgião cardiovascular e intensivista do Hospital São Joaquim da Real e Benemérita Sociedade Portuguesa de Beneficência de São Paulo, por me receber na Unidade de Terapia Intensiva em estado extremamente crítico e, no dia da alta hospitalar, mostrar-me que a minha vida segue em estado de graça e absolutamente normal, após um bem sucedido transplante cardíaco. Que toda a ciência e a humanidade que existe em seu coração continuem operando esses milagres e ajudando mais e mais pessoas que um dia enfrentarão uma fila de espera e de esperança. 
Ao Sr. José Fábio e Sra. Maria José, pais de minha esposa, deixo aqui minha homenagem pelos pais e sogros que são, e meus agradecimentos pelo constante incentivo para "estudar as bolinhas... mas sem perder a visão do Todo...", "fazer pular o abajur...", "deixar rasto..." e "por encontrar o Caminho...".

À minha cunhada Fabiana, pelo exemplo de seriedade, determinação $e$ responsabilidade com que enfrenta seus desafios e pelo amor e carinho para com seus sobrinhos. 
À minha querida esposa Ana Paola, muito obrigado não só por ser mãe dos nossos pequenos, mas principalmente, por me ensinar a ficar com os pés no chão quando eu teimava voar em condições adversas; e por me colocar nas alturas nas vezes em que eu caía, deixando um rasto de serenidade e delicadeza em suas intervenções. Nós dois sabemos o que significou esse trabalho e o que poderia precocemente sucedê-lo... O amor que nos une, os pequenos que nos completam e sua força de vontade e esperança frente às palavras desanimadoras (porém realistas) dos médicos, evidenciaram sua magnifica fortaleza de espirito, premiada com uma F.E.V.E. de 0,81\%... Sabemos a mágica desse número e tenho imenso orgulho em tê-la ao meu lado.

Aos pequenos Henrique e João Marcelo, meus filhos queridos. Só quem os tem sabe o significado pleno da palavra família e muito mais do que isso conhece profundamente o significado das palavras doação, carinho, companheirismo, amor, sacrifício, amizade e renúncia. Foram os principais responsáveis por eu ter adquirido uma postura extremamente otimista e perseverante frente aos obstáculos que precederam ao maior desafio de minha vida: mantê-la. 
Ao Professor Doutor César Antunes de Freitas, meu orientador, muito obrigado por me ensinar a gostar da Odontologia, por me aconselhar e me repreender, muitas vezes como "pai"; receba esta pequena homenagem pelo grande exemplo de docente, de pesquisador e de amigo. Homens honestos e integros como você fazem falta em nosso meio acadêmico.

Ao Dr. Van Benjamin Haywood, meu amigo, pela admiração por seu trabalho na área de Clareamento Dental e também pela oportunidade de conhecê-lo pessoalmente, ocasião em que a semente deste trabalho foi plantada.

Ao Professor Doutor José Mondelli, minha admiração e respeito por tudo o que representa para a Odontologia. Sinto-me muito feliz por desfrutar de sua amizade e sei que a recíproca é verdadeira. 
Aos colegas do Curso de Pós-graduação, Ana Rita, Elio, Oscar, Paulo Humaitá, Maria Carmen, Cristiane, Rodrigo, Aparício, Paulo Boer, Rosa Maria, Pedro, Willian, Renata, Humberto, Marcelo Agnoletti e muitos outros que, com certeza, tenho orgulho pela sadia amizade.

Aos meus amigos, funcionários do Departamento de Materiais Dentários, Sandra, Alcides e Lourisvalda, obrigado pelo apoio, pela amizade e pela paciência. Sou eternamente agradecido.

Ao casal Sérgio e Andrea Batagliotti, muito obrigado pela amizade, confiança, ajuda e convivência.

Ao casal Gustavo e Priscila Rossi Belmonte, colegas de trabalho que em tão pouco tempo mostraram-se como irmãos.

Ao casal Sérgio Scombatti e Adriana Silveira, agradeço por tê-los conhecido e por partilhar juntos nossos sonhos, conquistas e realizações.

Aos colegas de profissão, Dra. Gabriela Batagliotti, Dr. Belintani Filho, Dr. Laerte Godoy, Dra.Juliana Raineri, Dra. Carolina, Dra. Soraia.

À Valéria e Cybelle, e aos demais funcionários da Biblioteca. Sem a ajuda de vocês esse trabalho não seria o mesmo. 


\section{MEV RECONHECIMENTO}

- Aos Professores Doutores Gelson Luis Adabo, Willian Celso Rettondini (in memoriam), Deiwes Nogueira de Sá, Francisco Pedro Monteiro da Silva Filho e Carlos Alberto dos Santos Cruz, do Departamento de Materiais Odontológicos e Prótese, da Faculdade de Odontologia de Araraquara - UNESP, pelo desprendimento, seriedade científica, amizade e além de tudo, por serem responsáveis pelo início da minha carreira docente.

- Ao Professor Doutor Paulo Afonso Silveira Francisconi, pela grande amizade, pelas oportunidades oferecidas e pela virtude de enxergar a vida de uma maneira extremamente simples e sem complicações (às vezes até demais...).

- Ao Professor Doutor Oscar Barreiros de Carvalho Júnior, por partilharmos juntos os desafios, as tempestades e as conquistas no "percurso". Agora, com mar sereno, continue a sua rota de docência com a costumeira e impar competência...

- À Professora Doutora Odila Pereira da Silva Rosa, pela sincera amizade, pela competência profissional ímpar, por sua honestidade e pela capacidade em me ouvir e aconselhar nos momentos difíceis deste curso.

- Ao Professor Doutor Marco Antonio Húngaro Duarte, de pesquisador e profissional, muito obrigado pelos conselhos e pelas orientações do ponto de vista estatístico.

- Ao Professor Doutor Paulo Amarante de Araújo minha admiração e respeito, sobretudo pelos conselhos e conversas que tivemos no transcorrer deste curso.

- Ao Professor Doutor Eduardo Carlos Bianchi, do Departamento de Engenharia Mecânica da UNESP, Campus de Bauru, pela grande amizade e pelo consentimento em utilizar os aparelhos laboratoriais de precisão.

- Ao amigo Eraldo Jannone da Silva, mestrando do Departamento de Engenharia Mecânica da UNESP, Campus de Bauru, que pacientemente e com a máxima boa vontade deixava seus afazeres para auxiliar este trabalho durante os testes de rugosidade. 


\section{SUMÁRIO}

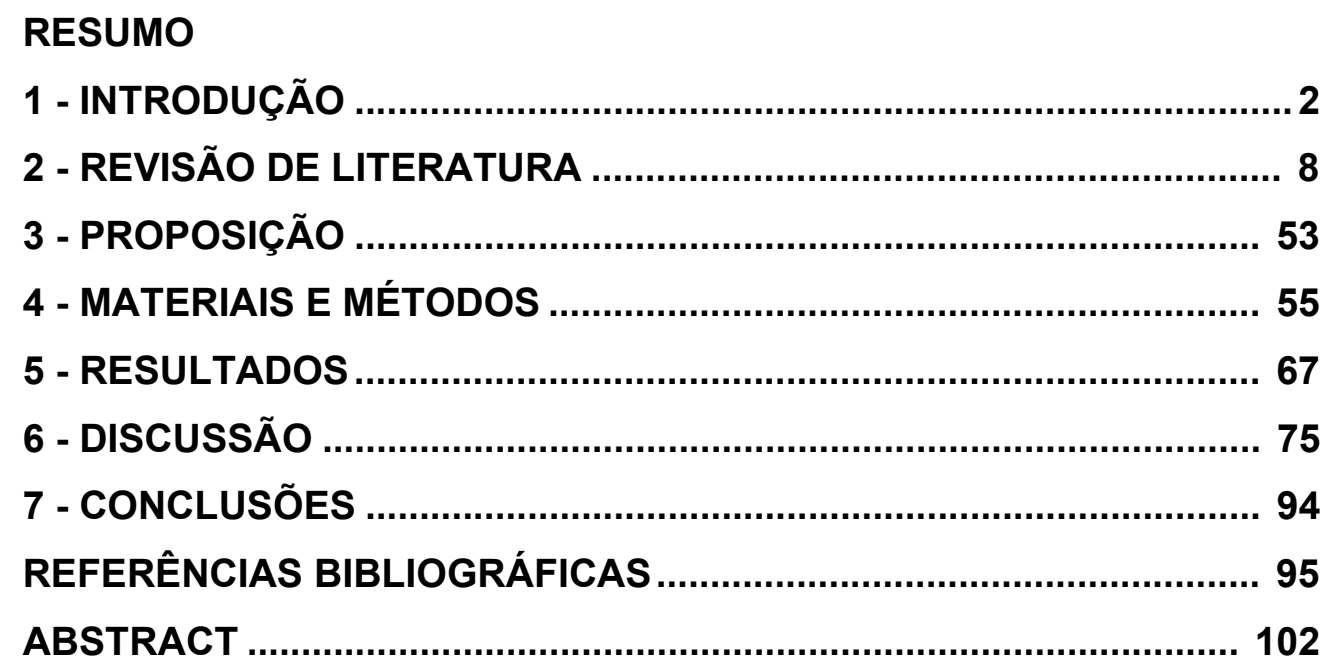


Resumo 


\section{RESUMO}

Foi avaliada a influência de três tipos distintos de agentes clareadores sobre a rugosidade e a dureza Vickers do esmalte bovino. Quarenta incisivos centrais inferiores foram divididos em quatro grupos: $1^{\circ}$.) água deionizada (controle); $2^{\circ}$.) peróxido de hidrogênio a $35 \% ; 3^{\circ}$.) Opalescence X-tra e $4^{\circ}$.) Opalescence Regular a $10 \%$. Os ensaios foram executados antes e depois dos tratamentos. As médias iniciais e finais obtidas de rugosidade (expressos em micrometros) foram, respectivamente, de 58,4 e 58,9 para os dentes do grupo 1, de 62,9 e 399,6 para os do 2, de 60,5 e 282,1 para os do 3 e de 56,4 e 58,5 para os do 4; quanto à dureza (expressos em números puros) foram, respectivamente, de 259,2 e 258,9 para os do grupo 1, de 256,7 e 172,8 para os do 2, de 259,7 e 213,1 para os do 3 e de 260,3 e 259,4 para os do 4 . Foi estatisticamente constatado que os espécimes dos grupos 2 e 3 mostraram alterações nas propriedades estudadas; consequentemente, receberam um tratamento adicional, denominado ameloplastia com ácido (através de uma aplicação do produto Opalustre), o qual permitiu a recuperação dos valores originais, para ambas as propriedades referidas. 


\section{1 - Introdução}




\section{1 - INTRODUÇÃO}

Dizem que uma das poucas coisas que diferenciam os seres humanos dos animais é o sorriso. A capacidade de sorrir que tem o homem o faz único e particularmente especial. Este gesto tem muitos significados e conotações, mas, antes de tudo, é a melhor demonstração de uma atitude favorável e positiva frente à vida. É também símbolo de alegria e uma poderosa arma de sedução; muitas pessoas sentem-se inibidas em emitir esse tipo de expressão facial por terem seus dentes em mau estado de conservação. Uma pessoa que sorri com dentes estragados não só causa má impressão naquelas que a cercam, mas também intimida e marca psicologicamente quem o possui.

Esse enfoque exprime um sentimento generalizado em nossa cultura que é a hipervalorização da aparência e, na nossa profissão, a Odontologia, da exagerada valorização do sorriso. Em virtude disso, nota-se, por parte dos pacientes, uma crescente procura por tratamentos estéticos relacionados com a melhora da aparência da dentição; por isto, há também uma grande demanda de profissionais que buscam cursos específicos, para poder satisfazer esses pacientes ávidos por consumir e usufruir a já popularizada "Odontologia Estética".

Dentre os tratamentos mais procurados pelos pacientes e estudados pelos profissionais de Odontologia está o Clareamento Dental, que é um dos menos destrutivos tratamentos disponíveis e que mais rapidamente traz algum resultado para o usuário das várias técnicas preconizadas. Basicamente, o tal procedimento pode ser denominado, segundo o local onde é realizado, em clareamento de consultório (quando é realizado em consultório odontológico) e em clareamento doméstico (quando o próprio 
paciente aplica o produto clareador em sua própria residência). Indistintamente do tipo, ambos são baseados em agentes oxidantes conhecidos como peróxidos, geralmente de hidrogênio ou de carbamida, ou ainda de uma mistura de ambos.

Os peróxidos são genericamente óxidos que contém mais oxigênio do que um óxido normal. Tais substâncias são encontradas em várias partes do corpo humano, como por exemplo, nas lágrimas, na saliva, nas sinapses neurais e nos tecidos inflamados. Sabe-se também que existe um potente sistema de enzimas que regula o aporte dos peróxidos nos tecidos vivos, mantendo em níveis fisiologicamente seguros a concentração dessas substâncias. Dentre as enzimas mais estudadas e conhecidas encontramos as catalases, as peroxidases e a superoxidodismutase. Tais enzimas têm a função de transformar o peróxido (com excesso de oxigênio) em seu óxido de origem, liberando assim uma espécie de oxigênio conhecido como oxigênio nascente.

O oxigênio nascente é um íon de vida efêmera, instável, e que se une a outras substâncias livres ou fracamente ligadas a um determinado substrato. Isto é possível graças à grande eletronegatividade do oxigênio, o que lhe confere um enorme poder de reação, pois esses íons buscam incessantemente a estabilidade molecular. Esse fenômeno oxidante ocorre, controladamente, milhares de vezes ao dia em nosso organismo, pois o oxigênio nascente é um dos radicais livres responsáveis pelo nosso envelhecimento, muito embora outras substâncias também colaborem para que isso ocorra. É provavelmente através de um mecanismo similar ao de óxido-redução ou de oxidação simples, provocado pelo oxigênio nascente, que a maioria das moléculas que mancham os dentes tornam-se mais simples, mais claras ou são eliminadas.

Dentro da Odontologia, os peróxidos têm sido empregados desde o século passado para uma infinidade de situações, como agente antibacteriano na irrigação de condutos radiculares e no tratamento de 
pericoronarites; como agentes de limpeza cavitária; como auxiliar na remoção da saburra no dorso da língua e nos casos onde se deseja tornar um ou todos os dentes mais claros.

O uso de peróxidos especificamente com a finalidade de clarear dentes não é recente, pois existem relatos da metade do século XIX, que já colocam o peróxido de hidrogênio como uma das substâncias capazes de alterar as cores dos dentes para tonalidades mais claras, diminuindo seu croma. Desde essa época várias substâncias foram empregadas com a mesma finalidade $5,15,17,22,23,31,32,67$, mas a supremacia dos resultados clareadores proporcionados pelo peróxido de hidrogênio, empregado puro ou como produto final da decomposição de outros peróxidos mais complexos, como o peróxido de carbamida, sempre foi incontestável.

Apesar disso, existem diversos relatos documentados na literatura ${ }^{2,20,29,30,37,41,43,45,47,52-54,57,60,61-65,68}$ afirmando que o uso indiscriminado dos peróxidos poderia afetar negativamente os tecidos duros e moles da cavidade bucal. Nos tecidos moles, são evidentes trabalhos científicos que sugerem riscos de queimaduras, de um possível efeito co-carcinogênico e de lesões diversas correlacionadas com o uso do peróxido de hidrogênio ou de carbamida. Nos tecidos duros, como o esmalte e a dentina, há estudos que concluem haver riscos de enfraquecimento do esmalte, aumento da rugosidade e também da porosidade e diminuição da sua dureza.

Com relação às propriedades dureza e rugosidade, há muita controvérsia em relação aos resultados dos estudos encontrados, sendo que a grande variação de metodologias empregadas possivelmente justifique esses achados. A importância em conhecermos os efeitos dos agentes clareadores mais representativos sobre o esmalte dental, principalmente ao avaliar a dureza e a rugosidade, poderia nortear quais tratamentos seriam os mais inócuos e conseqüentemente mais indicados para que obtivéssemos, além do efeito clareador, a máxima preservação da integridade dos tecidos duros dentais. 
Ao estudarmos a dureza, podemos defini-la como a resistência oferecida pelos sólidos à penetração de uma ponta, em condições bem definidas nas Normas atualmente existentes. Consiste em pressionar um penetrador de diamante (em forma de uma pirâmide regular com base quadrada e ângulo de vértice de $136^{\circ}$ ) contra um corpo-de-prova; a força de ensaio (F) e sua duração devem ser previamente escolhidas, obedecendo as citadas Normas; a intensidade da força aplicada dividida pela área da impressão (ou marca) resultante expressa a resistência à penetração de um determinado corpo de prova; tal número é conhecido como Número de Dureza Vickers (NDV) ou, ainda, mais comumente Vickers Hardness Number (VHN), na língua inglesa.

O estudo da rugosidade leva em conta o valor da média aritmética de todas as distâncias absolutas do perfil de rugosidade traçado, ou seja, da área percorrida pelo sensor de varredura de superfície. Toda superfície apresenta um certo grau de rugosidade, de imperfeições, ou ainda de depressões e elevações, que podem ser aqui denominadas de "picos" e "vales", respectivamente para as porções mais elevadas e menos elevadas. Através da varredura (ou "escaneamento") e leitura sobre os corpos de prova, por meio de um sensor, obtém-se valores numéricos da rugosidade, em termos da rugosidade média $(\mathrm{Ra})$.

Diversos trabalhos clínicos constantes na literatura especializada comprovam que o clareamento dental é uma técnica visualmente bastante efetiva, pouco destrutiva e com resultados duradouros. Apesar disso, pouco se sabe sobre o efeito das variações de concentração dos peróxidos relacionados com esse tipo de tratamento sobre a dureza e a rugosidade do esmalte, em condições que buscam a similaridade clínica. Há dúvida se alguma solução à base de peróxido poderia alterar tais propriedades do esmalte e, se isso realmente ocorrer, qual(is) procedimentos poderiam ser realizados para a recuperação da normalidade? 
Dessa forma, este trabalho teve como propósito avaliar comparativamente a dureza e a rugosidade provida pelo emprego sobre esmalte dental bovino de sóis de peróxido de carbamida a $10 \%$ e peróxido de hidrogênio a $35 \%$ e de peróxido de hidrogênio a $35 \%$ sob a forma líquida; avaliou-se também um método de recuperação da dureza e rugosidade originais, quando os valores da dureza e da rugosidade se mostrassem muito alterados. 


\section{2 - Revisão de literatura}




\section{2 - REVISÃO DE LITERATURA}

DWINELLE ${ }^{15}$, em agosto de 1850, no "American Journal of Dental Science", publicou uma série de experimentos com dentes despolpados, que caracterizaram a introdução do processo de clareamento dental na Odontologia. Neste artigo, afirmou que a idéia de clarear dentes manchados Ihe havia surgido naturalmente e que utilizara, para tanto, vários compostos contendo o íon cloro, vapores de enxofre e alguns ácidos, como o oxálico; usou cloreto de cálcio e de sódio, muitas vezes com bons resultados, formando uma pasta destes com fosfato de cálcio. Aventou a hipótese de que o mecanismo de ação do cloro provavelmente seria o de alcançar os pigmentos de ferro contidos nos tecidos dentários, oriundos do sangue, com eles reagir e fazer com que estes saíssem pelos "poros" do dente; também afirmou supor que talvez o ácido oxálico agisse como solvente do ferro. Uma sua conclusão foi de que os íons de cloro seriam o melhor meio para se eliminar manchas dos dentes.

Em setembro de 1861, na revista norte-americana "The Dental Cosmos", KINGSBURY ${ }^{31}$ publicou um artigo onde salientou a preocupação da comunidade odontológica com as "descolorações" dentais mais conhecidas na época, resultantes ou da aplicação de nitrato de prata (usado como dessensibilizante dentinário), ou da penetração de sangue nos túbulos dentinários, como em casos de necrose pulpar; neste trabalho, descreveu suas tentativas em promover o clareamento de dentes afetados nessas situações, pois valorizava a manutenção dos dentes naturais, ou da sua maior integridade possível, em detrimento de tal substituição por elementos ou substâncias artificiais. Frente a esses desafios, descreveu os vários experimentos realizados, até encontrar uma substância que considerou efetiva para o propósito de reduzir o "manchamento"; ilustrou o artigo, 
descrevendo um experimento bem sucedido numa paciente jovem, que apresentou necrose pulpar em dois dentes ântero-superiores onde, após a abertura da câmara pulpar, colocara um chumaço de algodão contendo tintura de iodo, com o objetivo de "neutralizar material necrótico"; após essa intervenção, aplicara cianeto de potássio, explicando que isto seria necessário não somente para remover as manchas provocadas pelo iodo, como para agir como um solvente da "hematina", que seria o corante dos glóbulos vermelhos. Informou que dissolvera dez grãos de cianeto de potássio em água, no momento de sua aplicação, formando uma solução que fora colocada na câmara pulpar, onde permanecera por 5 a 10 minutos, após o que houvera sido lavada com água tépida, para remoção total daquela solução. Observou que tal procedimento era mais vantajoso do que o com ácidos e outras substâncias, por produzir efeitos imediatos, na maioria dos casos.

BOGUE $^{5}$ publicou, em 1872, um artigo no "The Dental Cosmos" onde questionou aspectos de clareamento de dentes descoloridos devido ao extravasamento de sangue para dentro dos canalículos dentinários; relatou que, após o procedimento endodôntico, a cavidade pulpar deveria ser "perfeitamente limpa" e sofrer a aplicação de uma ou duas gotas de solução saturada de ácido oxálico por um tempo de três a seis minutos, o qual agiria como solvente para o íon ferro, existente nas hemácias; a câmara pulpar seria lavada com água, recebendo uma restauração provisória de cimento de oxicloreto de zinco; se não fossem necessárias outras sessões de clareamento, após algum tempo receberia uma restauração definitiva de ouro.

No ano de 1884, HARLAN ${ }^{23}$ relatou suas experiências bem sucedidas, durante um período de 18 meses, então com uma nova proposta de tratamento para clareamento de dentes despolpados, em que era necessário o uso de isolamento absoluto. Toda dentina manchada da cavidade pulpar coronária deveria ser removida, devendo esta ser limpa com peróxido de hidrogênio e então seca. O agente clareador principal utilizado 
era o cloreto de alumínio hidratado que, colocado em contato com a dentina seca, recebia uma ou duas gotas de água, iniciando-se o processo de clareamento pela liberação do íon cloro; a cavidade era então hermeticamente selada.

Em 1889, $\mathrm{KIRK}^{33}$ descreveu o que qualificou de possíveis mecanismos químicos do clareamento dental; em seu trabalho, afirmou que o sucesso do clareamento dental estaria na destruição dos pigmentos que afetavam as estruturas dentais, por um agente químico suficientemente adequado para tal propósito. Classificou as substâncias clareadoras em duas classes: as oxidantes e as redutoras; as primeiras destruiriam pigmentos pela remoção de hidrogênio; as segundas o fariam pela remoção do oxigênio. Dentre as substâncias oxidantes, citou o peróxido de hidrogênio, os cloretos e o permanganato de potássio; este último deveria ser reduzido pelo ácido oxálico, se não seu produto final marrom mancharia os tecidos dentários. Descreveu seu método de clareamento, baseado na liberação de ácido sulfúrico, a partir de uma mistura de sulfito de sódio (100 gramas) com ácido bórico (70 gramas); uma pequena porção desta era colocada na câmara pulpar, onde se adicionava uma gota de água; imediatamente a cavidade era fechada com guta-percha e assim mantida. Os resultados eram gratificantes, segundo o autor, acontecendo o clareamento mais rapidamente do que quando se usava o cloro.

HARLAN $^{22}$, agora em 1891, descreveu uma nova técnica, diferente da de 1884; nesta, a cavidade era lavada com água de cal, recebendo então uma solução de cloreto de cálcio; e uma outra de ácido sulfúrico a $3 \%$ era nela colocada, para promover a liberação de cloro, responsável pelo efeito clareador da dentina manchada.

$\mathrm{KIRK}^{32}$, agora em 1893, fez comentários a respeito do valor do peróxido de sódio como agente clareador de dentes, quando comparado com o peróxido de hidrogênio (utilizado na forma de um produto ao qual se 
referiu com pirozona*); afirmou que ambas as substâncias teriam como mecanismo de ação a liberação de oxigênio nascente, que por sua vez promoveria a oxidação de matéria orgânica, com conseqüente clareamento dos dentes. Descreveu um experimento onde avaliara a capacidade dos dois peróxidos em coagular proteína animal (albumina); o peróxido de hidrogênio, em várias concentrações (inclusive a pirozona), havia provocado a citada coagulação, enquanto que o de sódio não a promovera, inclusive agido exatamente ao contrário, ou seja, promovendo sua dissolução. Sua conclusão desse experimento foi que, se os pigmentos tivessem uma estrutura parecida com a da albumina, o peróxido de sódio os removeria mais facilmente. Afirmou que a vantagem do peróxido de sódio, em relação ao peróxido de hidrogênio, era, clinicamente, a obtenção de uma translucidez dentária mais próxima da natural.

WESTLAKE ${ }^{67}$, em 1895, descreveu o efeito cataforético da solução de pirozona a $25 \%$ na restauração da cor natural dos dentes, em poucos minutos, apresentando dois casos clínicos; informou que após o paciente ser anestesiado com cocaína, efetuava-se o isolamento absoluto do dente escurecido, procedendo-se à abertura coronária, remoção da polpa e limpeza da câmara pulpar (com um chumaço de algodão embebido em salmoura aquecida), nela colocando-se em seguida um outro chumaço de algodão embebido em pirozona a 25 \% (solução de peróxido de hidrogênio em éter etílico); então se aplicava o pólo positivo (ponta de uma agulha) de um aparelho de corrente galvânica no chumaço de algodão, com o respectivo pólo negativo seguro pela mão do paciente; a corrente galvânica era mantida ligada até que o algodão ficasse seco, quando se repetia todo o processo por mais duas vezes. Conforme o dente fosse ficando mais claro, a posição da ponta da agulha era alterada, para remover-se os pigmentos concentrados numa determinada região do dente; quando tal remoção fosse difícil, numa área, também o pólo negativo era posicionado nessa área do dente, externamente, promovendo-se um curto-circuito através do esmalte; após o procedimento clareador, o conduto era obturado e a cavidade restaurada com

* Pirozona consiste numa mistura de éter etílico e peróxido de hidrogênio a 35 \%, na proporção de 1:3. 
ouro; o dente, após o clareamento, apresentava aspecto de aparência natural, sendo que o procedimento clareador não demorava mais do que dez minutos.

Em 1911, FISCHER ${ }^{17}$ apresentou uma técnica de clareamento dental, com o uso de peróxido de hidrogênio, numa forma denominada "peridrol", para dentes despolpados; após instalação de dique de borracha, promovia a abertura coronária e a colocação de um chumaço de algodão embebido em peróxido de hidrogênio a 30 \% na câmara pulpar; uma gaze, também embebida pelo peróxido, era colocada em toda a volta da coroa dental e os olhos do paciente eram protegidos com uma toalha; a gaze era exposta à luz solar por uma hora e meia na primeira sessão, e uma hora nas subsequentes, com intervalo de três dias entre elas, motivo pelo qual o dente era restaurado provisoriamente, até a restauração definitiva feita com cimento de silicato; para dentes polpados, utilizava o peróxido de hidrogênio a $15 \%$, com bons resultados, como deixou registrado.

AMES $^{1}$, em 1937, escreveu um trabalho sobre a remoção de manchas em esmalte mosqueado, no qual afirmava que as manchas desse tipo poderiam ser causadas pela ingestão de água, e talvez de outros alimentos, com excessiva quantidade de fluoretos, durante o período de calcificação dentária, as quais poderiam ser removidas pelo método por ele preconizado, que consistia no emprego de uma mistura de cinco partes de peróxido de hidrogênio a 100 \% com uma parte de éter, em volume; após o isolamento absoluto do dente a ser tratado, um chumaço de algodão embebido naquela solução deveria ser sobre ele colocado, então sofrendo a ação clareadora de um instrumento aquecido, processo continuamente repetido por um tempo que variava de 30 minutos a 1 hora; fez a observação que, findo o tratamento, podia-se notar que as áreas não afetadas pelo manchamento estavam clareadas em demasia, sendo que essa pequena alteração voltava ao normal após duas a três semanas. 
PASHLEY; LIVINGSTON ${ }^{46}$, em 1978, publicaram os resultados de um estudo abordando o efeito do tamanho molecular de algumas substâncias sobre os coeficientes de permeabilidade na dentina humana; determinaram alguns efeitos do tamanho do raio molecular das substâncias estudadas sobre a taxa de permeabilidade de discos de dentina humana; as substâncias testadas foram a água, a uréia, um fluoreto, a lidocaína $^{* *}$, a glicose, a sucrose, a inulina, o dextrano, a polivinilpirrolidona iodada (PVPI) e a albumina; registraram que um aumento de 19 vezes no raio molecular, de 1,9 para 37 angstrons, resultava num decréscimo de 100 vezes no coeficiente de permeabilidade, calculado matematicamente pela "equação de Fick", e que o condicionamento da dentina com ácido cítrico a $50 \%$, por 2 minutos, produzira um aumento de 4 vezes na permeabilidade da água e um decréscimo de 9 vezes na da albumina, enquanto a do flúor e da clorexidina haviam ficado muito abaixo do esperado, levando-se em conta seus pesos ou tamanhos moleculares; concluíram que a permeabilidade dentinária era determinada, em parte, pela natureza da superfície dentinária.

Em fevereiro de 1986, CROLL; CAVANAUGH ${ }^{9}$, descreveram uma técnica para correção de manchas e irregularidades no esmalte, onde idealmente os resultados deveriam ser permanentes, com perda insignificante de estrutura dentária, não promovendo danos à polpa ou tecidos periodontais associados, com tempo clínico de aplicação reduzido e de fácil tolerância para o paciente. A técnica descrita por eles consiste na obtenção de uma pasta de ácido clorídrico a $18 \%$ e pedra-pomes. Previamente à aplicação desta pasta, os dentes devem ser isolados com dique de borracha e sob este, uma proteção adicional de bicarbonato de sódio e água é aplicada; a mistura de ácido clorídrico e pedra-pomes é então friccionada manualmente com uma espátula de madeira ou um instrumento envolvido em algodão sobre a superfície do esmalte. Após 5 segundos de aplicação, a superfície é lavada com água por 10 segundos. Em seguida, faz-se uma aplicação de flúor pelo tempo recomendado pelo fabricante do mesmo e, finalizando, é feito um polimento com pasta profilática fluoretada, com taças e discos específicos

\footnotetext{
${ }^{* *}$ N.T.: sal anestésico à base de 2-dietilamino-n-(2,6 dimetilfenil) acetamida.
} 
para esse fim. Os autores ressaltam a necessidade de proteção do paciente durante o procedimento: o ácido clorídrico é um agente extremamente cáustico e se não for manuseado cuidadosamente pode causar injúria ao paciente e profissional envolvido. Neste trabalho os autores mostraram, por meio de casos clínicos, a eficácia do método.

Em março de 1986, CROLL; CAVANAUGH ${ }^{10}$, publicaram outro artigo onde são apresentados casos onde manchas no esmalte foram tratadas com sucesso empregando a técnica de microabrasão com ácido clorídrico a $18 \%$ e pedra-pomes e outro onde as manchas eram muito profundas, não permitindo o sucesso da remoção por esta técnica. O emprego da pedra-pomes na técnica é justificado por impedir o escoamento do ácido clorídrico e também promover abrasão, aumentando a ação erosiva do ácido. Para os autores, um material ideal deveria ser um ácido clorídrico hidrossolúvel em forma de gel, com partículas abrasivas suspensas. Pode ser desejável diminuir a concentração do ácido e aumentar a abrasividade das partículas para tornar o tratamento mais fácil e seguro. Em nenhum dos pacientes apresentados houve reincidência da mancha após três e seis meses de observação, tendo inclusive mostrado melhora na cor com o passar do tempo, o que relacionaram com alterações ópticas benéficas associadas com a remineralização do esmalte.

Em maio de 1986, CROLL ${ }^{11}$, enfatizou que o único fator determinante do sucesso da técnica de microabrasão é a profundidade da mancha e que a técnica preconizada por ele, que é a mistura de ácido clorídrico a $18 \%$ com pedra-pomes, não impede o uso de outras técnicas de modificação de cor, podendo esta ser usada com outros métodos para melhorar a aparência estética. Foi relatado o caso clínico em que a técnica da microabrasão foi empregada previamente à restauração do dente com resina composta. Esta associação além de proporcionar melhora estética, simplificou a escolha da cor da restauração. Convém ressaltar que a realização do condicionamento ácido do esmalte com ácido clorídrico a 18\% 
não elimina o procedimento do condicionamento com ácido fosfórico a 37\%, antes da aplicação do adesivo.

BOWLES; UGWUNERI ${ }^{6}$, em 1987, observaram que os tecidos dentários são permeáveis ao peróxido de hidrogênio e que essa permeabilidade aumenta com a aplicação de calor. Esses resultados foram obtidos pela exposição da face vestibular de incisivos centrais superiores ao peróxido de hidrogênio a concentrações de 1,10 e $30 \%$ a $37^{\circ} \mathrm{C}$ por 15 minutos. Ainda neste trabalho, os autores expuseram 24 dentes ao peróxido de hidrogênio a $10 \%$, sendo um grupo à temperatura de $37^{\circ} \mathrm{C}$ e outro a $50^{\circ} \mathrm{C}$. a câmara pulpar desses dentes foi preenchida com solução tampão de acetato, que serviu como marcador da presença do peróxido de hidrog6enio. $\mathrm{Na}$ análise dos resultados, ficou evidente a maior difusão dessas substâncias em função da concentração apresentada pela solução e aumento de temperatura. Os autores comentam, que apesar de haver a penetração do peróxido de hidrogênio, os níveis alcançados são baixos, se comparados com aqueles produzidos pelas enzimas pulpares. Esse fato explicaria a razão pela qual os danos pulpares serem notavelmente baixos com o uso clínico dessa substância.

TITLEY; TORNECK; SMITH ${ }^{62}$, em 1988, avaliaram o efeito de uma solução de peróxido de hidrogênio a 35\%, que foi aplicada sobre fragmentos dentários por tempos que variavam de 1 a 60 minutos, sendo que algumas secções foram pré-tratadas com ácido fosfórico a 37\% por 60 segundos e outras foram pós-tratadas com ácido fosfórico por 60 segundos. Os autores observaram que nos dentes clareados com peróxido de hidrogênio foi verificada por meio de microscopia eletrônica de varredura, a presença de um "precipitado branco", conferindo à superfície do esmalte uma aparência de "congelado", como se houvessem partículas de gelo aderidas à sua superfície. A associação do pré ou do pós-tratamento com ácido fosfórico a $37 \%$ acima descrito, ainda segundo os autores, resultou na presença mais evidente do precipitado, e aumento da porosidade da superfície do esmalte. 
WANG; HUME ${ }^{66}$, em 1988, determinaram, "in vitro", a difusão dos íons hidrogênio e hidroxila, separadamente, provenientes de vários ácidos e de várias bases, através da dentina humana; também avaliaram a capacidade tampão da dentina e da hidroxiapatita, para ácidos e para materiais alcalinos, separadamente; puderam verificar, de maneira inesperada, que a difusão de íons $\mathrm{H}^{+}$, provenientes de ácidos inorgânicos fortes, ocorreu com caráter fraco ou então muito lentamente, num período de observação de 16 dias, quando, nas mesmas condições, água marcada com trítio difundiu-se rapidamente, numa taxa previamente esperada, como puderam prever, com base em outros de seus trabalhos anteriores. Também observaram que os íons $\mathrm{H}^{+}$, provenientes de ácidos fracos inorgânicos, atravessaram a dentina mais rapidamente do que íons $\mathrm{OH}^{-}$provenientes de materiais alcalinos; registraram que a dentina mostrou-se altamente efetiva na neutralização de soluções ácidas, atribuindo tal propriedade à hidroxiapatita e a outros componentes, mas que sua capacidade tampão para soluções alcalinas fora drasticamente menor, havendo porém evidências de que resultados melhores fossem alcançados com maior tempo de espera; sugeriram que a penetração dos íons $\mathrm{H}^{+}$, provenientes dos ácidos fortes, talvez tivesse sido pequena, por causa da alta eficácia de neutralização e remoção desse íons por um imediato tamponamento e pelo fato dos produtos de reação do tamponamento eventualmente terem também contribuído para a obliteração dos túbulos dentinários, depois de alguns dias; explicaram que, por outro lado, ácidos fracos tendem a permanecer em sua forma não dissociada, dessa maneira difundindo-se e escapando do efeito tampão; deixaram registrado que a capacidade tampão da dentina, frente às substâncias alcalinas, mostrou-se limitada, permitindo facilmente a difusão dos íons $\mathrm{OH}^{-}$.

Em março de 1989, HAYWOOD; HEYMANN ${ }^{24}$ descreveram uma técnica para clareamento de dentes vitalizados, na qual o paciente usaria uma moldeira individual carregada com o produto clareador, durante o período noturno, enquanto dormia, processo que ficou amplamente conhecido como clareamento doméstico ou caseiro; salientaram várias 
desvantagens do que denominou de tratamento tradicional para dentes vitalizados, feito à base de peróxido de hidrogênio, como o número excessivo de passos técnicos, a existência de efeitos colaterais, a necessidade de condicionamento ácido, o risco do uso de um peróxido tão concentrado que tornava necessária a proteção do paciente, o grande tempo clínico necessário para conseguir-se resultados satisfatórios, o custo elevado e o alto índice de recidivas num intervalo de 2 a 3 anos; afirmam que seu método oferecia segurança e era eficaz para dentes levemente descoloridos, citando como vantagens da técnica o fato de não ser necessário o condicionamento ácido, o menor tempo clínico, o menor custo para o paciente, a utilização de uma substância que não era cáustica, sendo porém fundamental a supervisão do tratamento, pelo Dentista. Sua técnica consistia, primeiramente, no registro da cor dos dentes do paciente, com uma escala de cores padronizada ou mediante fotografias, para posterior comparação; através de um molde de alginato, confeccionavam um modelo de gesso e, sobre este, uma moldeira plástica individual, para uso noturno; forneciam ao paciente um tubo de peróxido de carbamida a $10 \%^{\mathrm{a}}$, e o instruíam a depositar uma quantia do creme clareador nos espaços adequados da moldeira, especialmente criados para esse fim, e a dormir com esse dispositivo por aproximadamente 2 a 5 semanas; registraram que alguns problemas ocorriam no início do tratamento, como suave irritação localizada da gengiva, leve sensibilidade dolorosa a variações térmicas e pequeno desconforto, por sensibilidade dentária exacerbada, na primeira hora após remoção da moldeira, os quais desapareceram logo na segunda semana de tratamento; concluíram que o artigo, discorrendo sobre as vantagens desse tipo de clareamento, afirmando tratar-se de técnica conservativa e considerando-a como a primeira alternativa para tratar dentes levemente manchados, salientando, no entanto, que deveriam ser realizadas mais pesquisas sobre ela.

Em um artigo, em junho de 1989, McEVOY ${ }^{42}$ teceu considerações sobre as técnicas de remoção de manchas, o mecanismo de

\footnotetext{
a Proxigel, Reed \& Carnrick Pharmaceuticals, E.U.A.
} 
ação do peróxido de hidrogênio e suas aplicações clínicas. Afirmou que o modo de ação do peróxido de hidrogênio, para a remoção de manchas associadas a fluorose, injúrias ou tetraciclinas, é muito difícil de ser descrito, por causa do pequeno conhecimento a respeito do assunto; talvez este processo ocorresse, como descreveu, no esmalte e na dentina, provavelmente através de um mecanismo de oxidação dos pigmentos, causado pelo oxigênio liberado, que então efetuaria uma limpeza mecânica; ainda afirmou que o esmalte era bastante permeável ao peróxido de hidrogênio, tanto devido ao baixo peso molecular deste, como à sua habilidade em desnaturar proteínas, acontecendo assim um grande movimento iônico através dos tecidos dentários, podendo-se associar o calor, para maiores rapidez e eficácia da reação, apesar de existirem controvérsias sobre tal aspecto, especialmente no que diz respeito tanto ao tempo e à temperatura empregados, como aos efeitos deletérios causados nos tecidos pulpares; ainda afirmou que o peróxido de hidrogênio removeria manchas superficiais do esmalte, com a vantagem de não promover sua desmineralização, sendo portanto um método seguro e conservativo.

Em outubro de 1990, HAYWOOD; HOUCK; HEYMANN ${ }^{26}$ não encontraram alterações morfológicas na superfície do esmalte humano, analisado em microscopia eletrônica de varredura, quando este foi exposto a quatro diferentes produtos clareadores. O grupo I foi tratado com Proxigel, produto de baixo pH e liberação lenta de oxigênio. O grupo II com Gly-Oxide, com elevado $\mathrm{pH}$ e rápida liberação de oxigênio. No grupo III, foi usado o White \& Brite com alto $\mathrm{pH}$ e liberação moderada de oxigênio. Todos esses produtos acima citados são à base de peróxido de carbamida a $10 \%$. No último grupo, aplicou-se o Peroxil, um gel a base de peróxido de hidrogênio a $1,5 \%$, possuindo baixo $\mathrm{pH}$. O tratamento teve duração total de 250 horas. Esses espécimes foram comparados com o grupo controle, onde nenhum tratamento foi aplicado e, com o um grupo, condicionado com ácido fosfórico a $37 \%$. Nesse trabalho, as superfícies de todos os grupos diferiram significantemente, apenas quando comparado com o grupo condicionado com ácido fosfórico. Os autores comentam que os produtos com baixo $\mathrm{pH}$ 
não causam desmineralização do esmalte, pois a solução de peróxido é instável e, quando em contato com a saliva ou tecidos rapidamente se dissocia. O peróxido de carbamida a 10\% desmembra-se em peróxido de hidrogênio a $3 \%$ e uréia a $7 \%$. O peróxido de hidrogênio degrada-se em oxigênio e água e enquanto que a uréia em amônia e dióxido de carbono, sendo esta responsável pela elevação do $\mathrm{pH}$.

HAYWOOD et $\mathrm{al}^{27}$, em 1991, utilizando microscopia eletrônica de varredura, verificaram o efeito do peróxido de carbamida a $10 \%$ na superfície de esmalte de trinta e três pré-molares que foram usados nesse estudo. A coroa desses dentes foi dividia ao meio e apenas a metade mesial foi exposta ao gel clareador, perfazendo um total de 240 horas, sendo que no intervalo de sete horas de aplicação diária do agente clareador, os dentes permaneciam em saliva artificial. A outra metade foi selada para evitar contato com peróxido e serviu como controle. Foram analisadas as réplicas das superfícies de esmalte em aumento de 100x, 200x, 1000x e 5000x. Dentes não tratados e condicionados com ácido fosfórico a $37 \%$ foram preparados visando a comparação com os outros grupos. As fotomicrografias revelaram não haver diferença entre as superfícies tratadas ou não com peróxido de carbamida, diferenciando-se, entretanto, em relação ao grupo tratado com ácido. Outro aspecto observado foi que dos 33 dentes, 15 não apresentaram alteração de cor. Em todos os dentes não houve diferença de cor entre a face coberta e a exposta ao clareador, indicando a alta difusibilidade do peróxido de carbamida pela dentina.

TITLEY; TORNECK; RUSE ${ }^{63}$, em janeiro de 1992, avaliaram o efeito de diferentes produtos à base de peróxido de carbamida, com diferentes valores de $\mathrm{pH}$, nos valores de adesão da resina composta ao esmalte ácido-condicionado, bem como avaliar se o tempo contado após o condicionamento do esmalte influenciaria na força de adesão. Para fazer valer tal propósito, tomaram 90 dentes bovinos que estavam divididos e dez grupos, sendo que os últimos dois grupos continham cinco dentes cada um, e 
os demais, dez dentes. O peróxido de carbamida foi empregado da seguinte maneira:

\begin{tabular}{cccc} 
Grupo & Produto & Tempo de uso & pH \\
\hline 1 & Peróxido de carbamida & 3 horas & 4,7 \\
2 & Peróxido de carbamida & 6 horas & 4,7 \\
3 & Peróxido de carbamida & 3 horas & 7,2 \\
4 & Peróxido de carbamida & 6 horas & 7,2 \\
5 & Solução salina & 3 horas & 7 \\
6 & Solução salina & 6 horas & 7 \\
7 & Solução salina & 3 horas & 7 \\
8 & Solução salina & 6 horas & 7 \\
9 & Peróxido de carbamida & 6 horas com restauração após 1 dia & 7,2 \\
10 & Peróxido de carbamida & 6 horas com restauração após 7 dias & 7,2 \\
\hline
\end{tabular}

Após o período de tratamento, o grupo 9 recebeu restauração de resina composta após 1 dia da aplicação do agente clareador e o grupo 10, após 7 dias; os dentes nesse período ficaram imersos em água destilada. Os autores observaram que a aplicação do peróxido de carbamida, tanto por três horas, como por seis horas, resultou numa diminuição significante na força de adesão da resina ao esmalte, não ficando evidenciada a influência do $\mathrm{pH}$ do agente clareador nessa situação. Após um dia e uma semana em água destilada, os valores da força de adesão tenderam a retornar aos valores encontrados no grupo controle, resultando inclusive, valores maiores que aqueles encontrados neste grupo.

CVITKO; SWIFT; DENEHY ${ }^{14}$, em fevereiro de 1992, apresentaram casos em que o clareamento caseiro foi indicado para melhorar os resultados obtidos com a microabrasão. O paciente apresentava manchas marrons nos incisivos centrais e laterais superiores. Foi usado o Prema (mistura de ácido clorídrico a 10\% com carborundo), que removeu completamente as machas sem alterar o contorno dos dentes. A microabrasão reduziu a espessura do esmalte resultando em maior 
transparência e aparecimento da coloração amarelada da dentina e o clareamento caseiro foi realizado, aprimorando o aspecto final.

Em maio de 1992, CROLL $^{12}$ descreveu dois casos clínicos nos quais foram empregados a microabrasão e, posteriormente, a técnica de clareamento. $\mathrm{Na}$ primeira situação, o esmalte apresentava manchas de etiologia desconhecida, mas que aparentemente era resultante de ingestão excessiva de dentifrício fluoretado e manchas extrínsecas decorrentes de prática inadequada de higiene oral. Na segunda, foram detectadas lesões cervicais descalcificadas associadas a remoção inadequada de placa e também desmineralizações brancas generalizadas, dando aos dentes uma aparência riscada amarela e branca. Com a resolução destes casos, empregando as duas técnicas, verificou-se que o clareamento caseiro melhora a aparência dos dentes que se apresentam escuros ou amarelos, após a realização da microabrasão. Porém, devido à diminuição na espessura do esmalte após a microabrasão, é possível que este tratamento combinado possa predispor o paciente à sensibilidade pulpar. A formação da camada lustrosa, lisa e sem primas, que apresenta melhorias com o tempo, aparentemente não foi alterada pelo clareamento.

BITTER $^{4}$, em junho de 1992, comparou o efeito de três produtos clareadores, comercialmente denominados Rembrandt Lighten, Ultra White e Natural White, sobre a superfície do esmalte, por intermédio do microscópio eletrônico de varredura, constatando alterações significantes na superfície do esmalte após 30 horas de exposição aos agentes clareadores à base de peróxido de carbamida a 10\%, com um pH de 6,8. Nos grupos que empregaram os agentes clareadores que preconizam um pré-tratamento com produtos que contém ácido cítrico, ácido fosfórico e peróxido de hidrogênio, foi observado aumento da porosidade e áreas de dissolução superficial do esmalte, salientando ainda que a adição do efeito da escovação em conjunção com o efeito dos agentes clareadores deve ser considerado. 
Em junho de 1992, ROTSTEIN; LEHR; GEDALIA ${ }^{52}$ publicaram um trabalho relatando o efeito de alguns agentes clareadores sobre os componentes inorgânicos da dentina e do cemento humanos. Para tanto, trituraram dentes humanos íntegros até obterem pó, do qual extraíram o cemento e a dentina, separados devido à diferença da gravidade específica de ambos; submeteram os tecidos pulverizados a tratamentos, respectivamente, com peróxido de hidrogênio (a $30 \%$ e a $3 \%$ ), a perborato de sódio a $2 \%$ associado com peróxido de hidrogênio (também a $30 \%$ e a 3 \%) e a perborato de sódio associado com água bidestilada, por períodos, também respectivos, de 15 minutos, 1, 24 e 72 horas. Mediram o grau de dissolução e a porcentagem de material inorgânico de ambos, dentina e cemento, através de espectrofotometria por absorção atômica, para íons cálcio; notaram que os tratamentos com peróxido de hidrogênio a $30 \%$ ou com perborato de sódio a $2 \%$ associado com peróxido de hidrogênio a $30 \%$ aumentaram significantemente a solubilidade de ambos os tecidos; também puderam observar que o grau de dissolução e a porcentagem de material inorgânico apresentaram níveis diretamente proporcionais à progressão do tempo de exposição da dentina e cemento não dissolvidos. Encontraram os maiores graus de solubilização dos tecidos como aqueles causados pelo peróxido de hidrogênio a $30 \%$ e pelo perborato de sódio a $2 \%$ associado com o peróxido de hidrogênio a $30 \%$, tanto depois de 24 horas como de 72 horas de tratamento. Concluíram que tal tratamento com peróxido de hidrogênio a $30 \%$ poderia causar alterações químicas na estrutura da dentina e do cemento, deixando-os mais susceptíveis à degradação.

HAYWOOD $^{25}$, em julho de 1992, revisou a literatura para estudar o emprego do peróxido de hidrogênio nas três técnicas profissionalmente então executadas, abordando aspectos históricos, assim como cada técnica propriamente dita; fez comentários sobre a segurança dos métodos ao longo do tempo, subdividindo-a em segurança absoluta e relativa para os clareamentos não-vital e vital em consultório, para o caseiro, dentre os quais aqueles feitos com produtos vendidos sem prescrição. Discutiu as vantagens e as desvantagens das diferentes opções de clareamento, 
algumas indicações específicas e situações em que se deveria fazer a combinação das várias técnicas.

MURCHINSON; CHARLTON; MOORE ${ }^{45}$, avaliaram no período setembro/outubro de 1992, a influência na resistência adesiva e na microdureza do esmalte, de três tipos de agentes clareadores à base de peróxido de carbamida. Foram selecionados 80 pré-molares divididos em quatro grupos, com aplicações diárias por cinco dias consecutivos, dos seguintes produtos comerciais: Opalescence Regular por 9 horas, White \& Brite por 18 horas e Dentlbright por 18 horas, sendo que o quarto grupo serviu como controle. Durante o período experimental, os dentes ficaram estocados a $37^{\circ} \mathrm{C}$ a $100 \%$ de umidade. Após cada dia de tratamento, os dentes eram lavados com água deionizada para remoção do peróxido de carbamida e estocados em saliva artificial. Após 48 horas do término de aplicação dos agentes clareadores, foi realizado o condicionamento com ácido fosfórico a 37\%, na região, por 15 segundos, para em seguida ser aplicado um adesivo ortodôntico quimicamente ativado, e proceder dessa forma a colagem do "bracket" na superfície do esmalte tratado. Os dentes foram termociclados por aproximadamente 27 horas, totalizando 2.500 ciclos com temperatura variando de 5 e $45^{\circ} \mathrm{C}$, com banhos de 30 segundos em cada temperatura. A resistência adesiva foi medida pelo intermédio da máquina Instron com velocidade de $0,5 \mathrm{~mm} /$ minuto e o local da fratura, avaliado com auxílio de estereomicroscópio para determinar e classificar a falha em adesiva, coesiva ou mista. Para a análise da microdureza do esmalte, cinco dentes de cada grupo foram separados. Três medidas foram feitas para cada dente, tomadas antes e após o tratamento clareador, com o aparelho Knoop Hardness Tester, obtendo-se a média final das três aferições. De acordo com os resultados, os autores concluíram que o tratamento clareador com peróxido de carbamida em curto tempo, não afeta os procedimentos adesivos e a superfície de esmalte, entretanto, recomendam que a superfície seja limpa com taças de borracha antes do procedimento adesivo e que se aguarde 48 horas para realizá-lo. 
McGUCKIN; BABIN; MEYER ${ }^{43}$, em novembro de 1992, publicaram um trabalho onde foi analisada a possível alteração na morfologia do esmalte, sob a luz da microscopia eletrônica de varredura, quando o uso de agentes clareadores estariam indicados. Para tanto, três agentes clareadores foram selecionados e testados: Proxigel (peróxido de carbamida a $10 \%$, com carbopol e pH de 4,7), fabricado pela empresa Reed \& Carnrick; White\&Brite (peróxido de carbamida sem carbopol, pH de 6,2), produzido pela indústria Omni Products International, Gravette, Ark) e Superoxol (peróxido de hidrogênio 30\%, com pH 3,0), fabricado pela Union Broach, York, $\mathrm{Pa}$, que foi o único produto aplicado após condicionamento ácido do esmalte com ácido fosfórico a $37 \%$. Os resultados, segundo os autores, evidenciaram uma tendência ao alisamento do esmalte após a aplicação dos produtos de uso caseiro, ou seja, baseados em peróxido de carbamida a $10 \%$; os resultados do grupo que empregou peróxido de hidrogênio a $35 \%$ precedido de condicionamento ácido apresentaram imagens sugestivas e concordantes com o aspecto do referido condicionamento. O aumento da porosidade neste último grupo experimental, tanto pode ser devido à ação do peróxido, devido ao seu baixo $\mathrm{pH}$, ou da própria ação do ácido, que foi aplicado previamente ao agente clareador.

CHEN; XU; SHING ${ }^{7}$, no mês de janeiro de 1993, determinaram a taxa de decomposição do peróxido de hidrogênio, frente a várias condições pela verificação do número de moléculas de oxigênio liberadas, tanto em soluções ácidas como básicas, inclusive analisando o efeito do calor e de íons metálicos. Os autores discorreram sobre a química dos peróxidos, chamando a atenção para aspectos químicos da respectiva reação de clareamento; usaram peróxido de hidrogênio a $30 \%$, isoladamente, ou misturado com ácido hidroclorídrico ou éter anestésico, ou ainda com hidróxido de sódio a 20 \% ou finalmente com cloreto de ferro III. Afirmaram que tais misturas teriam provocado uma decomposição do peróxido em água e oxigênio. Suas conclusões, que denominaram como preliminares, resumidamente informam que tal decomposição: 1) em geral havia sido acelerada pelo calor; 2) para o peróxido de hidrogênio a $30 \%$ fora 
rápida e mais violenta do que aquelas observadas nas soluções com ácido hidroclorídrico, com éter e com peróxido de hidrogênio, entre 16 e $20^{\circ} \mathrm{C}$; 3 ) havia sido violenta quando da mistura com cloreto de ferro III pulverizado, ocasião em que a solução foi contaminada com partículas marrons, que poderiam vir a manchar os dentes; e 4) se necessitava de posteriores estudos em relação ao proporcionamento tradicionalmente usado nas soluções com ácido hidroclorídrico, éter e peróxido de hidrogênio.

Em janeiro de 1993, SHANNON et al. ${ }^{54}$ avaliaram os possíveis efeitos adversos do peróxido de carbamida na estrutura do esmalte, combinando uma metodologia "in vivo" e "in vitro". Pequenos fragmentos de esmalte previamente autoclavados foram fixados em um dispositivo de acrílico removível, parecido com uma placa de Hawley e posicionados na boca de pacientes para avaliar o efeito de três agentes clareadores à base de peróxido de carbamida sobre a microdureza e também sobre possíveis alterações na superfície do esmalte, simulando condições próximas às que ocorrem num tratamento clareador. Após aplicação dos produtos à base de peróxido de carbamida a 10\% (Proxigel, Rembrandt e Gly-Oxide), com pH variando de 4,3 a 7,2 por quatro semanas, com um tempo de aplicação diário de 15 horas, fora da cavidade bucal, verificaram ao microscópio eletrônico de varredura alterações na superfície do esmalte, que se caracterizavam por um padrão irregular e tênue semelhante ao condicionamento ácido, com pequenas áreas de destruição superficial. Houve correlação entre o maior grau de destruição e o menor pH do agente clareador correspondente.

TONG, L.S.M. et $\mathrm{al}^{65}$ publicaram os resultados de seu trabalho sobre os efeitos do clareamento com peróxido de hidrogênio a $30 \%$ e da microabrasão na superfície do esmalte, em janeiro de 1993. Sob a óptica da microscopia de luz polarizada e também pela eletrônica de varredura, verificaram que o peróxido de hidrogênio a $30 \%$ aplicado por 30 minutos sobre a superfície do dente e ativado por luz, não demonstrou capacidade de alterar o esmalte estruturalmente, ao passo que com a aplicação prévia de ácido fosfórico a $37 \%$ por 30 segundos houve perda de 
estrutura de esmalte; o ácido clorídrico, comumente utilizado nas técnicas de microabrasão, mostrou-se extremamente agressivo, ficando claro que não houve perda de esmalte quando o tratamento fora somente com peróxido, enquanto nos demais houve uma perda de aproximadamente 5,3+1,6 m e $360 \pm 33$ m respectivamente.

Em março de 1993, TITLEY et al $^{64}$ analisaram "in vitro" a força de adesão da resina composta ao esmalte dental humano, tratado previamente com peróxido de hidrogênio a 35\% durante um tempo de 60 minutos, constatando uma força de adesão de 18,2+8,8 Mpa no grupo controle, ao passo que no grupo experimental essa força foi de $7,1+4,8 \mathrm{Mpa}$, ficando claro que houve uma grande diminuição na força de adesão nos espécimes do grupo tratado com peróxido de hidrogênio a 35\%. No outro grupo, os espécimes ficaram imersos em água destilada por um dia, depois da aplicação do peróxido de hidrogênio a 35\%, após o qual foi aplicada a resina composta; este grupo mostrou uma força de adesão de 11,7£4,8. Apesar de ter sido verificada uma restituição da força de adesão após um dia de imersão em água destilada, esses valores não se mostraram estatisticamente significantes.

HAYWOOD et $a^{28}$ publicaram em setembro de 1994, um artigo onde foram avaliados os efeitos colaterais do peróxido de carbamida, produto comumente empregado na técnica caseira de clareamento. De acordo com os autores, dentre os 38 pacientes incluídos no estudo, 66\% apresentaram algum tipo de efeito colateral após o uso do clareador, que fora aplicado por seis a oito horas durante a noite, ou durante o dia, trocando-se o material clareador a cada duas ou seis horas. Do total, cinqüenta e dois por cento apresentaram sensibilidade dentária, com ou sem inflamação gengival; $31 \%$ dos pacientes relataram irritação gengival com ou sem sensibilidade dentária; 34\% mostraram sinais claros de sensibilidade dental apenas; 13\% tiveram irritação gengival e 18\% conjugaram irritação gengival e sensibilidade dental. Os autores deixaram claro que, após um período que variou de 1 a 32 dias, houve completa remissão de qualquer sintomatologia. 
Em sua tese de doutorado, SOUZA ${ }^{57}$ avaliou por meio de microscopia eletrônica de varredura em 1993, o efeito de diferentes marcas comerciais de peróxido de carbamida na superfície do esmalte dental. Com um grupo de espécimes tratados continuamente por 240 horas e outro grupo tratado de forma intermitente, também por 240 horas a autora observou que a exposição contínua e sem ativação dos géis clareadores, produziu erosão nas porções mais elevadas do esmalte referentes às bordas das depressões terminais dos prismas; observou-se uma grande variação no aspecto morfológico da superfície do esmalte, com a evidenciação das depressões referentes às marcas deixadas pelos processos de Tomes, tornando mais nítido os acidentes anatômicos, e até mesmo um "alisamento da superfície", revelando uma aparência suavizada, como se estivesse "recoberta por um véu". Todos os géis testados (Proxigel, Reed \& Carnrick; Rembrandt, DenMat Corp.; Opalescence, Ultradent) produziram um aumento de porosidade na superfície do esmalte dental. Comparativamente, a ação remineralizadora de uma formulação de saliva artificial foi analisada após os dentes serem posteriormente condicionados com ácido fosfórico a 37\%, após o tratamento com peróxido de carbamida, repousando em saliva artificial ou em água destilada; nos espécimes que ficaram imersos em saliva artificial, quando comparados aos espécimes imersos em água destilada, houve uma diminuição dos espaços entre os cristais, nos fragmentos que ficaram imersos em saliva, tanto no esmalte prismático quanto no aprismático, observados após condicionamento com ácido fosfórico por 15 segundos, sugerindo que a saliva desempenhe ação remineralizadora.

A diminuição da microdureza dos tecidos dentais duros após o tratamento clareador implica em sua dissolução e degradação. O efeito na microdureza do esmalte e dentina exposto ao peróxido de hidrogênio a 30\% e a pasta de perborato de sódio misturado ao peróxido de hidrogênio em diferentes tempo e temperatura foi avaliado por LEWINSTEIN et $\mathrm{al}^{37}$, em fevereiro de 1994. Utilizaram 12 dentes recém-extraídos, que foram seccionados longitudinalmente, embebidos em resina acrílica, polidos e divididos em quatro grupos de acordo com o tratamento estabelecido. Os 
tratamentos foram, peróxido de hidrogênio a 30\%, peróxido de hidrogênio a $30 \%$ associado ao perborato de sódio submetidos a temperaturas de 30 e $50^{\circ} \mathrm{C}$. As medidas da dureza do esmalte foram tomadas antes do procedimento e após 5, 15 e 30 minutos. Houve um grupo controle, onde os mesmos critérios de avaliação foram aplicados, porém tratados com água destilada. Utilizou-se o aparelho de dureza Vickers para as aferições, com carga de 300gramas. Os resultados indicaram que o peróxido de hidrogênio diminuiu a microdureza tanto do esmalte quanto da dentina, sendo significante após 5 minutos de tratamento para dentina e 15 minutos para o esmalte. Esse efeito não foi observado com a aplicação da pasta de peróxido de hidrogênio associado ao perborato em nenhum tempo de tratamento. $A$ temperatura não exerceu nenhum efeito para ambos os grupos. Os autores concluíram que o tratamento com altas concentrações de peróxido de hidrogênio com finalidade de clareamento, seja usada com cautela e que o perborato de sódio apresentou-se como um material menos danoso aos tecidos dentais.

\section{Em agosto de 1994, LEONARD JUNIOR; BENTLEY;} HAYWOOD ${ }^{35}$ estudaram as mudanças do $\mathrm{pH}$ salivar, em procedimentos de clareamento caseiro com peróxido de carbamida a $10 \%$, pois a desmineralização do esmalte poderia ocorrer já num pH entre 5,2 a 5,8, e alguns agentes clareadores possuem pH ainda mais ácido (entre 4,8 e 5,2), que poderia aumentar o risco de cárie, pela desmineralização do esmalte. Para tanto, tiveram a colaboração de quatro adultos, cujas arcadas superiores foram moldadas para confecção de moldeira individual, a qual receberia o agente clareador; no decorrer de vinte sessões de clareamento caseiro, mediram o pH salivar, entre as 13:30 e 17:00 horas, sendo que os colaboradores foram orientados a não comer, beber ou fumar, duas horas antes de cada mensuração; coletavam a saliva em frascos e a analisavam num pH-metro, usando como controle àquela colhida antes da primeira instalação da moldeira, nas condições de salivação estimulada ou não. Em seus resultados, não encontraram diferenças entre os dois modos de salivação, mas observaram significante queda do $\mathrm{pH}$ nos primeiros cinco 
minutos; puderam notar que aos dez minutos essa diferença deixou de existir e que o valor do $\mathrm{pH}$ aumentou, até o final do experimento. Advertiram que os dentistas não deveriam pensar apenas numa melhora estética do sorriso de seus pacientes, mas também que poderia existir um risco maior de desmineralização dos tecidos dentários; no entanto, afirmaram que tal risco era pequeno quando do uso do peróxido de carbamida, pois os produtos resultantes da decomposição desse peróxido (principalmente a uréia) tendiam a elevar o $\mathrm{pH}$.

PÉCORA et $\mathrm{al}^{47}$, em 1994, estudou a microdureza da dentina após a aplicação de vários agentes clareadores. Para tanto, foram confeccionados discos de dentina, com $1 \mathrm{~mm}$ de espessura, a partir de 36 incisivos superiores humanos. Foram avaliados os seguintes produtos clareadores: 1) perborato de sódio; 2) perborato de sódio com água; 3) perborato de sódio e peróxido de hidrogênio a 3\%; 4) perborato de sódio e peróxido de hidrogênio a 35\%; 5) Endoperox (peróxido de carbamida a 35\%, em pó comprimido); 6) Proxigel (peróxido de carbamida a 10\%) e 7) peróxido de hidrogênio a $30 \%$. Ficou muito bem demonstrado que após 72 horas a $37^{\circ} \mathrm{C}$ todos os agentes clareadores testados neste estudo reduziram a microdureza da dentina. O peróxido de carbamida em pó comprimido (Endoperox) e o peróxido de hidrogênio a $30 \%$ foram os que proporcionaram maior queda na microdureza da dentina.

Em dezembro de 1994, LEONARD JUNIOR et al. ${ }^{36}$ verificaram as alterações do $\mathrm{pH}$ da placa dental e da solução de peróxido de carbamida a $10 \%$, ocorridas durante o processo de clareamento de dentes vitais, por duas horas; após verificar os valores iniciais do $\mathrm{pH}$, para a placa e para o peróxido de carbamida, criaram um pequeno orifício na região anterior da moldeira, para permitir a colocação do eletrodo do $\mathrm{pH}$-metro. Mediram o pH do peróxido de carbamida, a intervalos de 5 minutos, sendo que depois de 2 horas removeram a moldeira e o $\mathrm{pH}$ da placa com saliva foi novamente medido; consideraram todas as medidas como o resultado médio de três 
medições; puderam verificar que o pH inicial da placa foi de 6,31 e a média final foi de 6,86, o que consideraram como diferença significante. Constataram que, no momento da colocação do peróxido de carbamida na moldeira, seu $\mathrm{pH}$ era de 4,5 e no final encontraram uma diferença estatisticamente significante no valor de 8,06; notaram que os valores do $\mathrm{pH}$ da placa dental, da saliva e do peróxido de carbamida contido dentro da moldeira sofreram um aumento significante, durante o processo de clareamento, tendo permanecido significativamente altos por todo o período de duração do estudo; acharam que isso ocorreu, possivelmente devido à característica muito instável do peróxido de carbamida a $10 \%$, intraoralmente, pois assim, ele se dissociaria em $3 \%$ de peróxido de hidrogênio e $7 \%$ de uréia, que por sua vez, respectivamente, se dissociariam em água + oxigênio e amônia + gás carbônico. Deixaram registrado que tais reações seriam catalisadas por enzimas salivares, como peroxidases e catalases, encontradas em muitos fluidos orgânicos e em algumas bactérias; que o peróxido de hidrogênio seria o ingrediente ativo do peróxido de carbamida, atóxico e não alergênico, capaz de destruir uma grande variedade de microorganismos; que a uréia seria uma substância bacteriostática, capaz de dissolver tecido necrótico, permitindo com que uma ferida se cicatrizasse rapidamente; e que a liberação de amônia e dióxido de carbono, durante a degradação da uréia, elevariam o valor do $\mathrm{pH}$, reduzindo assim, o risco em relação a uma possível desmineralização do esmalte, quando por ocasião do uso do peróxido de carbamida a $10 \%$, para fins de clareamento.

BEN-AMAR et al. ${ }^{3}$ observaram em fevereiro de 1995, através de microscopia eletrônica de varredura, a superfície de esmalte dental humano que sofreu exposição ao peróxido de carbamida a $10 \%$ por oito horas diárias, pelo intervalo de três semanas consecutivas; foram encontradas alterações morfológicas na superfície do esmalte, ficando evidente a presença de algumas áreas com variados graus de porosidade, bem como áreas de superfície bem aplainadas. Os autores salientam que tais alterações não foram uniformes em toda a superfície do esmalte e também 
constataram a diminuição na força de adesão de compósitos às superfícies de esmalte recém-clareadas.

GOLDSTEIN; GARBER ${ }^{19}$, em 1995, publicaram um livro intitulado "Complete Dental Bleaching", onde vários aspectos da arte de clarear dentes são abordados, como a ação química dos agentes clareadores, o diagnóstico e o plano de tratamento, o clareamento em si, quer em consultório, quer caseiro, de dentes despolpados ou não. A técnica de clareação de dentes polpados em consultório, com peróxido de hidrogênio a $35 \%$, é aqui descrita em detalhes: 1) profilaxia com pedra pomes e água, para remoção de placa bacteriana e pigmentos extrínsecos: 2) proteção do tecido gengival com uma pasta de bicarbonato de sódio (Oraseal - Ultradent Products Inc.); 3) isolamento dos dentes a serem clareados com dique de borracha; 4) nova profilaxia para remoção do excesso de Oraseal; 5) nos casos de dentes excessivamente manchados, é feito um condicionamento ácido por 5 a 7 segundos com ácido fosfórico a 37\% para potencializar a penetração da solução clareadora; 6 ) rinsagem da solução de ácido fosfórico por 30 segundos; 7) estando os dentes limpos, condicionados e secos, coloca-se uma fina tira de gaze hidrófila saturada com uma solução de peróxido de hidrogênio a $35 \%$, como o produto comercial Superoxol, cobrindo todos os dentes a serem clareados; 8) posiciona-se uma fonte calorífica (The Illuminator - Union Broach) a uma distância de aproximadamente 30 centímetros perpendicularmente à superfície vestibular dos dentes a serem clareados, iniciando o aquecimento da solução clareadora com $115^{\circ} \mathrm{F}$, aumentando lentamente até quando o paciente não relatar sensibilidade, sendo que as temperaturas limítrofes médias situam-se entre 115 e $140^{\circ} \mathrm{F}$. a temperatura ideal, entretanto, situa-se num patamar de $10^{\circ}$ abaixo da temperatura que desencadeia sensibilidade dolorosa para aquele determinado paciente; 9) o tempo de ação da fonte aquecedora varia de 20 à 30 minutos por sessão, sendo que constantemente dentro desse intervalo de tempo a solução clareadora deve ser reaplicada com um cotonete ou contagotas, mantendo-se em contato com o esmalte; 10) remove-se a gaze e lavase copiosamente; remove-se as amarias e o dique de borracha; 11) pule-se o 
esmalte com pontas de óxido de alumínio de grana decrescente (Shofu Cosmetic Contouring Kit); 12) aplica-se solução de fluoreto de sódio neutro a $1,1 \%$, para prevenção de sensibilidade; 13) após hidratação do esmalte, fazse um polimento do esmalte usando-se pastas polidoras empregando-se taças de borracha.

LEE et al. ${ }^{34}$, em 1995, estudaram os efeitos do peróxido de hidrogênio a 50\% Accel Brite Smile (Birminghan, $A L$ ) e de dois tipos de peróxido de hidrogênio a 35\%, respectivamente 35\% Accel Brite Smile (Birminghan, $A L$ ) e Hi Lite (Shofu, Menlo Park, CA) sobre a microdureza do esmalte, observando também através de microscopia eletrônica de varredura, uma possível influência desses compostos nos aspectos morfológicos da superfície do esmalte. Todos os espécimes, com exceção do grupo controle apresentaram alteração no aspecto superficial do esmalte quando observados pelo MEV. No grupo clareado com o produto $50 \%$ Accel Brite, o esmalte apresentou-se com densidade relativamente aumentada na superfície das fossas e depressões e pobre definição de periquimácias; nos outros dois grupos clareados com o peróxido de hidrogênio a 35\%, respctivamente $35 \%$ Accel Brite e $\mathrm{Hi}$ Lite, as periquimácias superficiais apresentaram uma imagem com melhor definição e maior densidade superficial das fossas em relação ao grupo controle. Mesmo frente a esses resultados, os autores são categóricos ao afirmar, no que se refere à efetividade dos materiais clareados testados, num total de duas horas cada um, não houve diferença estatisticamente significante entre eles, ou seja, a concentração ou a marca comercial não influenciou no resultado obtido. Entretanto, o peróxido de hidrogênio de maior concentração promoveu maiores alterações na superfície do esmalte.

SOUZA; BERGAMASCHI; SOUZA ${ }^{56}$, tiveram o propósito de estudar em 1996, o efeito "in vitro" do peróxido de carbamida na superfície do esmalte de dente humano, comparando a morfologia do esmalte clareado ao condicionamento ácido com ácido fosfórico a 37\%. Foram utilizados cinco terceiros molares seccionados no sentido mesiodistal e vestibulolingual 
totalizando quatro partes. Somente o esmalte permaneceu exposto, sendo o restante da coroa coberta com esmalte de unhas. Cada segmento recebeu diferente tratamento: Grupo A: tratamento clareador de 12 horas + armazenamento em saliva artificial (12 horas) + condicionamento ácido; Grupo B: tratamento clareador + armazenamento em água destilada (12 horas) + condicionamento ácido; Grupo C: armazenamento em saliva artificial; Grupo D: armazenamento em água destilada. O período de experimento para todos os grupos foi de 20 dias. A seguir os dentes foram escovados e lavados com água destilados, imersos em hipoclorito de sódio por 20 minutos e depois submetidos ao ultra-som por cinco minutos. As secções foram estocadas individualmente por quatro horas em água destilada e condicionadas com ácido fosfórico a $37 \%$ por 15 segundos, lavadas e secas. Os espécimes foram preparados para a análise no microscópio eletrônico e fotografados com 1000, 5000 e 10000 vezes de aumento. Observou-se aumento nos espaços intercristalinos no grupo que recebeu o tratamento clareador, verificando-se ainda que esses espaços eram menores quando os espécimes ficaram armazenados em saliva artificial, evidenciando a ação remineralizadora da saliva. Em relação ao padrão de condicionamento I, II e II, este foi modificado quando se usou o gel clareador. O alargamento dos espaços intercristalinos verificado com o uso do peróxido de carbamida, levou os autores a concluir que essa substância age nos componentes orgânicos do esmalte.

Em janeiro de 1996, ERNST; MARROQUÍN; ZONNCHEN ${ }^{16}$ verificaram 0 efeito da aplicação de quatro agentes clareadores (Opalescence, HiLite e peróxido de hidrogênio a $30 \%$, este último isoladamente ou associado ao perborato de sódio) e do ácido fosfórico, sobre a superfície externa do esmalte humano, observada ao microscópio eletrônico de varredura; também mediram o pH das soluções estudadas, não tendo informado por qual método, encontrando os valores médios de 2, para o peróxido de hidrogênio a 30 \%, 8 para a mistura peróxido de hidrogênio a $30 \%$ + perborato de sódio, 6 para o HiLite, 6 para o Opalescence e 1 para o ácido fosfórico. Aplicaram estes agentes individualmente nas superfícies de 
esmalte de 60 amostras, obtidas a partir de 10 dentes, sendo que cada agente foi aplicado em uma amostra de cada dente, das quais uma permaneceu sem tratamento; comparando o aspecto observado das superfícies tratadas com a de controle, puderam observar que o esmalte exposto aos agentes clareadores sofreu pequenas alterações morfológicas superficiais, apenas em uma amostra tratada com peróxido de hidrogênio a $30 \%$ e em duas amostras tratadas com o HiLite, ao passo que naquelas amostras tratadas com ácido fosfórico a 37\% a alteração morfológica sempre se mostrara de caráter severo.

No mês de janeiro de 1996, ROTSTEIN et al. ${ }^{53}$ fizeram um análise histoquímica dos tecidos duros dentários, após processos de clareamento; usaram 22 premolares humanos extraídos, dos quais removeram os dois terços apicais da porção radicular e cujos cotos remanescentes cortaram longitudinalmente, obtendo dois espécimes semelhantes, os quais foram lavados, secos e distribuídos por seis grupos experimentais de igual número de espécimes, respectivamente tratados com um dos seguintes materiais: 1) solução de peróxido de hidrogênio a 30 \%; 2) solução de peróxido de carbamida a 10\%; 3) solução de perborato de sódio; 4) NuSmile; 5) Opalescence e 6) DentalBright. Tal tratamento consistiu na imersão dos espécimes em seus respectivos materiais, seguindo-se sua armazenagem em estufa a $37^{\circ} \mathrm{C}$, por sete dias; decorrido esse tempo, mediram os níveis de cálcio, fósforo, enxofre e potássio no esmalte, na dentina e no cemento. No esmalte, observaram uma significante diminuição na relação cálcio/fósforo $(\mathrm{Ca} / \mathrm{P})$ para o peróxido de hidrogênio a 30 \%; na dentina, também detectaram significante redução desta relação para o peróxido de hidrogênio a $30 \%$, o peróxido de carbamida a $10 \%$, assim como para o DentalBright e o Opalescence; no cemento, também observaram tal redução, de forma significante, para o peróxido de hidrogênio a $30 \%$, peróxido de carbamida a $10 \%$, assim como para o $\mathrm{Nu}$ Smile e o Opalescence. Relataram redução significativa nos níveis de enxofre destes tecidos somente para o cemento tratado com o peróxido de carbamida e o perborato de sódio e seu aumento significante com o Nu Smile; puderam 
observar significante redução nos níveis de potássio, somente na dentina tratada com peróxido de carbamida. Concluíram que os materiais para clareamento podiam afetar adversamente os tecidos duros dos dentes, devendo, por isso, ser usados com cautela.

JOSEY et al. ${ }^{29}$, em abril de 1996, observaram alterações na superfície e na subsuperfície do esmalte após tratamento clareador com peróxido de carbamida a 10\%. Em seu experimento constataram que após a aplicação de dez horas diárias, pelo intervalo de uma semana do peróxido de carbamida a $10 \%$ puro sobre o esmalte, houve alterações evidenciadas tanto pela microscopia óptica quanto pela eletrônica de varredura, o que sugere perda mineral, pois sob as condições do experimento, tais alterações mantiveram-se por um período de 12 semanas após o clareamento mesmo nos dentes armazenados em saliva artificial, o que demonstra, segundo os autores, que o tempo não promoveu o retorno da aparência superficial normal do esmalte clareado.

ZALKIND et al. ${ }^{68}$, em abril de 1996, investigaram possíveis alterações morfológicas no esmalte, na dentina e no cemento humanos, após a aplicação de alguns materiais clareadores empregados para branqueamento dental; para tanto empregou 21 pré-molares recém-extraídos que foram seccionados longitudinalmente no sentido vestibulo-lingual, em dois segmentos; uma camada do cemento, de cada segmento, foi removida de modo que a dentina ficasse exposta. Os espécimes foram divididos em sete grupos, sendo um controle e os demais tratados, por sete dias a $37^{\circ} \mathrm{C}$, com os seguintes materiais clareadores: 10solução aquosa de peróxido de hidrogênio a $30 \%$; 2) solução aquosa de peróxido de carbamida a 10\%; 3) pasta de perborato de sódio com água (2 gramas por mililitro) e 4) três produtos comercialmente encontrados, que foram: $\mathrm{Nu}$ Smile (M\&M Innovations, USA), Opalescence (Ultradent USA) e DentalBright (Cura Phamaceuticals, USA). Sob o microscópio eletrônico de varredura, os autores observaram que ocorreram alterações morfológicas nas estruturas dentárias após o tratamento com a maioria dos materiais clareadores, sendo que o 
cemento foi o tecido mais afetado, recomendando-se muita cautela durante o uso de tais produtos.

Segundo LORENZO et al. ${ }^{38}$, em junho de 1996, o sistema $\mathrm{Hi}$ Lite Dual Activated Bleaching System (Shofu Dental Corporation, USA) consistia de um líquido contendo peróxido de hidrogênio a $35 \%$, misturado a um pó constituído por várias substâncias, entre elas persulfinato de potássio, sulfato de manganês monoidratado, sulfato de ferro, sílica amorfa hidratada, polimetil éter maleato de potássio e corante verde guiné. Dessa mistura resultava um creme indicado tanto para clareamento de dentes vitalizados, como desvitalizados, aplicado em consultório, sob isolamento absoluto e após condicionamento com ácido fosfórico a $37 \%$, por 15 segundos. Tal creme deveria ser mantido em contato com os tecidos dentais (esmalte, extracoronalmente, e dentina, intracoronalmente), por 4 minutos, se o produto fosse oxidado por luz proveniente de lâmpada halógena, ou por nove minutos, se tal oxidação ocorresse por ação puramente química. Descreveram a história de três casos clínicos, tratados com este produto, onde alguns detalhes citados eram interessantes, como por exemplo: 1) havia necessidade de condicionamento prévio de esmalte e de dentina com ácido fosfórico a $37 \%$, por 15 segundos; 2) como o produto podia ser empregado até o máximo de seis vezes, numa mesma sessão, nesta condição notava-se um espetacular clareamento já ao final da primeira sessão, mas dois dias após, significante retorno para a cor alterada inicial observada; 3) esse efeito clareador observado ao final da primeira sessão, associado ao efeito da desidratação proporcionado pelo isolamento absoluto do campo operatório, poderia explicar a dramática redução do manchamento (alteração de cor), após o final de cada sessão; 4) a subseqüente reidratação dos tecidos dentais e a hipotética neo-redução das moléculas pigmentadas (previamente oxidadas durante o processo clareador) poderiam explicar a recidiva. Chamaram ainda a atenção para não se deixar o HiLite como curativo de demora (à semelhança do que era feito na técnica de NUTTING; $P O E^{58}$ ), para se prevenir qualquer efeito indesejável, como reabsorção cervical externa, salientando a necessidade de novas investigações, à respeito da 
estabilidade das cores conseguidas e de possíveis efeitos adversos que poderiam vir a ocorrer, tanto nos dentes, quanto no tecido periodontal.

MCCRACKEN; HAYWOOD ${ }^{41}$, em novembro de 1996, efetuaram um estudo em nove dentes humanos recém-extraídos, com a intenção de dosar a quantidade de cálcio removido da superfície do esmalte dentário após a exposição a diversas soluções de peróxido de carbamida a $10 \%$, por um período de seis horas e de refrigerante comercialmente disponível, por um período de 2,5 minutos. Os dentes expostos à solução de peróxido de carbamida a 10\% apresentaram significante perda de cálcio quando comparado ao grupo controle, onde os dentes foram expostos à água destilada. A quantidade de cálcio perdida variou de 0,54 a $1,95 \mu \mathrm{g} / \mathrm{mm}^{2}, \mathrm{com}$ uma média de $1,06 \pm 0,16 \mu \mathrm{g} / \mathrm{mm}^{2}$. Para avaliar as implicações clínicas dessa perda de cálcio após a exposição ao peróxido de carbamida a 10\%, a mesma experiência foi realizada expondo os dentes à um refrigerante, que demonstrou haver uma perda de cálcio variando de 0,0 a $3,93 \mu \mathrm{g} / \mathrm{mm}^{2}$, com média de $1,25+0,15 \mu \mathrm{g} / \mathrm{mm}^{2}$. A análise estatística permitiu informar que não houve diferença estatisticamente significante entre a quantidade de cálcio pedida dos dentes imersos por 2,5 minutos em refrigerantes e os dentes tratados com peróxido de carbamida a 10\%, sugerindo afirmar que, embora tais alterações ocorridas na superfície adamantina após a aplicação do produto clareador, seu significado clínico deva ser re-examinado, visto que quantidades similares de cálcio são perdidas com a exposição do dente a refrigerante por 2,5 minutos.

ATTIN et al. ${ }^{2}$, em abril de 1997, fizeram um trabalho onde foi avaliado o efeito do peróxido de carbamida e a subseqüente aplicação de flúor sobre a propriedade da microdureza do esmalte bovino. A superfície vestibular dos dentes foi desgastada com um disco de carborundo sob refrigeração, e polida com pastas diamantadas entre 15 a $5 \mathrm{~m}$, o que removeu aproximadamente $200 \mathrm{~m}$ de esmalte superficial e expôs uma suficiente área de superfície de $4 \mathrm{~mm}^{2}$ para a medida da dureza. Os espécimes foram fixados em pastilhas de resina epóxica, e suas superfícies 
polidas ficaram perpendiculares ao longo eixo do diamante penetrador. $\mathrm{O}$ peróxido de carbamida a 10\% (Opalescence regular) foi aplicado puro, com o auxílio de pequenas moldeiras individuais, por períodos de 12 horas, intercalado por um período de oito horas imerso em solução remineralizadora de saliva artificial. Os sessenta dentes, divididos em quatro grupos de quinze dentes cada um, receberam previamente os seguintes tratamentos: 1) aplicação de verniz Duraphat (Woelm, Eschwege, Germany), durante a primeira hora de armazenamento na saliva artificial e remoção do mesmo após esse tempo, sendo o espécime devolvido ao meio de saliva artificial por mais sete horas; o tratamento clareador foi o descrito acima; 2) esmalte tratado com fluoreto de sódio a $0,2 \%$ e depois o peróxido de carbamida foi aplicado como descrito acima; 3) esmalte tratado somente com o clareador e armazenado em saliva artificial e 4) esmalte que, ao invés de ser clareado, foi imerso em água destilada. Os autores afirmaram que o procedimento clareador reduziu de forma drástica e estatisticamente significante a microdureza do esmalte bovino e que a aplicação de fluoretos mostrou um aumento na microdureza do esmalte superficial.

Em abril de 1997, CROLL ${ }^{13}$ afirmou que após dez anos de pesquisas e experiência clínica, a microabrasão é aceita como um método conservador e não-invasivo para melhorar a aparência de dentes com defeitos superficiais no esmalte. Por eliminar a porção manchada do esmalte, os resultados obtidos são permanentes. Foi detalhada a técnica empregando apenas a microabrasão e também quando simultaneamente o peróxido de carbamida a $10 \%$ foi utilizado, segundo a técnica de clareamento caseiro, visando a obtenção de resultados mais satisfatórios quando os dentes apresentam escurecimento. Fotografias ilustram a eficácia da técnica e o caráter permanente do tratamento, com proservação de até dois anos.

Em abril de 1997, FLOYD ${ }^{18}$ abordou, oportunamente, em seu trabalho, vários aspectos da ação dos peróxidos e dos radicais de oxigênio livre, que são denominados espécies de oxigênio reativo, sobre os tecidos de quaisquer sistemas vivos que usam oxigênio; estas substâncias estão 
presentes dentro de muitos tipos de células, em muito baixas concentrações, porque existem sistemas protetores antioxidantes que previnem seu acúmulo; após afirmar que os peróxidos usados para clarear dentes podem causar danos, se usados inadequadamente, escreveu que este seu trabalho fornecia informações básicas sobre a ação dos peróxidos nos tecidos corpóreos, as quais o dentista poderia usar para executar, de forma segura, o clareamento dentário com estas substâncias. Citou, entre outros aspectos, que o peróxido de hidrogênio era uma substância formada durante a respiração, que a catalase o decompunha em água e oxigênio, enquanto a peroxidase o fazia em oxigênio, juntamente com vários produtos de oxidação, e que a recémdescoberta enzima superóxido-dismutase fez iniciar uma grande quantidade de pesquisas que apontaram o fato novo de que os radicais de oxigênio livre e o peróxido de hidrogênio são importantes subprodutos no metabolismo do oxigênio. Acentuou que em todos os sistemas biológicos aeróbicos existe um estado de equilíbrio metabólico entre a capacidade de defesa antioxidante e o potencial de dano oxidativo, apontando quatro pontos importantes à respeito das respostas teciduais frente a fenômenos de caráter oxidativo: 1) as células normalmente são submetidas a grandes quantias de tensão oxidativa, por causa de seu metabolismo normal; 2) a susceptibilidade das células a essa tensão depende, entre outros fatores, da sua idade e da sua reserva de substâncias antioxidantes; 3) tecidos inflamados contêm leucócitos que, ao realizar fagocitose, produzem radicais de oxigênio livre e assim expõem os tecidos vizinhos a uma tensão oxidativa adicional e 4) danos oxidativos significantes das moléculas (como proteínas e DNA), acima dos níveis basais indicam excessiva tensão oxidativa. Deixou registrado que as tensões oxidativas têm sido classificadas em três categorias (de níveis, respectivamente, baixo, moderado e intenso), as quais conceituou; manifestou seu ponto de vista de que os dentistas têm efetuado um uso prudente dos peróxidos e que o uso do peróxido de carbamida com moldeira é um tratamento adequado, que requer prática e conhecimento, pois esses fatores diminuem a possibilidade de graves danos oxidativos na cavidade oral. 
A associação do tratamento para remoção de manchas superficiais do esmalte e clareamento de dentes vitalizados empregando o Prema e o Opalescence 10\%, respectivamente, foi relatada, em 1997, por SUNDFELD et al. $^{59}$. Verificou-se que esta associação possibilitou a recuperação estética do sorriso do paciente, com a técnica da microabrasão removendo manchas localizadas nas camadas mais superficiais do esmalte dental e o clareador caseiro promovendo o clareamento dos dentes que tornaram-se um pouco amarelados após a realização da microabrasão. Após um mês da realização dos procedimentos não ocorreu retorno de coloração e os dentes tratados mantiveram o brilho e a lisura superficial.

CREWS et $\mathrm{al}^{8}$, em 1997, avaliaram as possíveis alterações químicas na superfície do esmalte após a aplicação dos agentes clareadores peróxido de hidrogênio a $10 \%$, peróxido de carbamida a $15 \%$ e peróxido de carbamida a $10 \%$ com carboxipolimetileno; constataram um aumento na porcentagem de Ca e $\mathrm{P}$ nos dentes clareados, o que poderia ser explicado como resultado de uma perda dos componentes orgânicos do esmalte, fazendo com que os componentes inorgânicos apareçam em maior concentração.

No período de janeiro e fevereiro do ano de 1998, BITTER ${ }^{4}$, com a intenção de avaliar o efeito de alguns agentes clareadores sobre a superfície do esmalte dos dentes de três pacientes que se submeteriam à extração completa, para posterior reabilitação com prótese total, submeteu-os primeiramente a sessões de clareamento com peróxido de carbamida a $10 \%$, pela técnica caseira, por 14 dias, com 30 minutos diários de exposição. 0 autor observou, após as extrações, sob a luz da microscopia eletrônica de varredura, alterações que variaram desde a remoção parcial da camada aprismática do esmalte até severa exposição dos prismas, com áreas compatíveis com a desmineralização do esmalte. Essas alterações foram evidentes até nos últimos dentes a serem extraídos, o que ocorreu depois de 90 dias de finalizado o tratamento clareador. Segundo o autor, essas alterações no esmalte, provocadas pelos agentes clareadores baseados no 
peróxido de carbamida a $10 \%$ podem perdurar por longo tempo. Os pacientes devem ser informados quanto ao potencial dos agentes clareadores alterarem o esmalte.

RIEHL, H. ${ }^{48}$, em fevereiro de 1998, analisando a suspeita de que o baixo $\mathrm{pH}$ de agentes clareadores pudessem resultar em danos às estruturas dentárias e adjacências, verificou, em vários momentos (idades) de seus períodos de ação efetiva, 0 pH de 8 substâncias empregadas rotineiramente nos procedimentos de clareamento dental: 1- água deionizada; 2- peróxido de hidrogênio a 30\%; 3- Hi Lite (produto clareador à base de peróxido de hidrogênio a 35\%); 4- Opalescence 10\% (produto clareador à base de peróxido de carbamida à 10\%); 5- pasta de perborato de sódio monohidratado (PSM) com água deionizada; 6- pasta de PSM com peróxido de hidrogênio a 30\%; 7- pasta de PSM com solução anestésica e 8- pasta de PSM com Opalescence $10 \%$. Para as pastas com perborato de sódio, foi detectado um valor inicial sempre de neutralidade ou alcalinidade, cujo valor aumentava com o passar do tempo; os valores do Opalescence, da água deionizada e do peróxido de hidrogênio a 30\% não apresentaram variações, permanecendo no mesmo nível de acidez durante todo o experimento; o HiLite mostrou-se também sempre ácido, no início com pH 4,2, terminando com 4,9. Estes resultados permitem contestar a afirmação de que todos materiais contendo peróxido de hidrogênio tenham caráter ácido, assim invalidando a hipótese deles serem rotineiramente responsabilizados pela ocorrência daquela reabsorção.

TAMES; GRANDO; TAMES ${ }^{60}$, no período março/abril de 1998, observaram alterações no padrão morfológico da superfície do esmalte dentário, após a aplicação do peróxido de carbamida a 10\% (Opalescence), após imersão dos espécimes no referido agente clareador por quatro semanas. Os autores observaram um aumento da porosidade superficial do esmalte, com um aumento de poros visivelmente maiores, de morfologia afunilada ou não afunilada; o afunilamento sugere, segundo os autores, a destruição de camadas subseqüentes de esmalte em torno dos mesmos. 
Segundo os autores, houve um aumento no diâmetro dos poros de esmalte em todas as amostras analisadas, no entanto, áreas de esmalte com aspecto semelhante ao normal foram observadas entre regiões de maior porosidade. Salientam ainda que tais alterações não ocorreram com a mesma intensidade e de maneira concomitante em todas as amostras estudadas.

RIEHL ${ }^{50}$, no período maio/junho de 1998, contestou o trabalho de TAMES; GRANDO; TAMES ${ }^{60}$, que fora publicado no exemplar anterior do mesmo periódico. O autor contesta as afirmações sobre os possíveis achados "in vitro" e suas correlações clínicas, salientando que todos os agentes clareadores atualmente baseados em peróxido de carbamida a $10 \%$ contém glicerina que, por ser anidra, causa um certo grau de desidratação clinicamente verificável e que o método empregado pelos autores do referido trabalho criticado empregou 336 horas de exposição dos fragmentos de esmalte ao citado peróxido, com apenas 20 minutos de repouso entre uma sessão e outra, tempo esse que parece insuficiente para que ocorra a reidratação. Sugere que os espécimes sejam mantidos em repouso por mais tempo e, de preferência, em saliva artificial, numa tentativa de reproduzir mais fielmente o que ocorre clinicamente e ainda questiona qual o método empregado para decompor o peróxido de carbamida no citado trabalho, já que clinicamente essa função é basicamente desempenhada pelas enzimas salivares, o que aumentaria o grau de conversão de peróxido de carbamida em um dos seus produtos finais, o oxigênio nascente, que atuaria aumentando a eficácia do tratamento clareador.

RIEHL, $H^{49}$, ainda em 1998, relatou em editorial alguns aspectos relacionados com o tema clareamento dental, esclarecendo aspectos relativos às técnicas mais empregadas, ao que relata a literatura especializada e principalmente à segurança quanto ao uso dos peróxidos na Odontologia. O autor ressalta que existem três técnicas de clareamento dental, classificadas aqui de acordo com o local onde o tratamento será realizado: totalmente feito em consultório; iniciada no consultório e continuada em casa pelo próprio paciente, sob orientação profissional, e a 
oferecida diretamente ao paciente, sem orientação do C.D. Todas se valem do uso de peróxidos de hidrogênio ou de carbamida. Salienta ainda que, se o paciente respeitar as orientações que o C.D. prescrever, não há risco nenhum em fazermos o clareamento caseiro. Entretanto, é preciso deixar bem claro que o papel de vilão imposto ao clareamento caseiro deve-se exatamente ao fato de não podermos controlar eficientemente o uso do agente clareador, que pode ser comprado nas dentais por pacientes mais afoitos em ter um sorriso mais claro, num tempo rápido demais.

MENDES ${ }^{44}$, em março de 1999, apresentou em sua tese de doutorado uma completa avaliação da quantidade de desgaste, por meio de microscopia óptica, avaliando também a textura superficial com o auxílio de um rugosímetro e também a morfologia superficial através de microscopia eletrônica de varredura após a microabrasão de esmalte humano com ácido clorídrico a $18 \%$, ácido clorídrico a $18 \%$ + pedra-pomes, Prema, ácido fosfórico a $37 \%$ e ácido fosfórico a 37\% + pedra-pomes. Para a avaliação da quantidade de desgaste foram empregados fragmentos trapezoidais, da superfície vestibular de molares humanos, obtidos por seccionamento, os quais foram divididos em cinco grupos (30 espécimes cada) que foram subdivididos em três subgrupos de acordo com o números de aplicação dos compostos (5, 10 e 15 aplicações, em um total de 150 corpos-de-prova. Os materiais foram aplicados com uma ponta de borracha abrasiva cilíndricocircular, integrante do conjunto comercial Prema, que era presa ao contraângulo, girando em baixa velocidade controlada. Após cada aplicação de dez segundos, as superfícies foram lavadas por 20 segundos com água deionizada e secas por 20 segundos, levadas ao fotomicroscópio Zeiss para leitura e cálculo das medidas de desgaste; depois dessas medidas, os corpos-de-prova foram polidos com disco Sof-Lex extra-fino por 20 segundos e novamente realizada a avaliação da quantidade de desgaste. De acordo com a análise estatística, o polimento promoveu desgaste semelhante para todos os grupos; ao considerar o desgaste total (microabrasão + polimento), as comparações individuais pelo teste de Tuckey mostraram que $\circ \mathrm{HCl}$ a $18 \%$ misturado à pedra-pomes promoveu a maior remoção de esmalte, 
seguido em ordem decrescente pelo $\mathrm{HCl}$ a $18 \%$, ácido fosfórico a $37 \%+$ pedra-pomes e Prema. Baseado nestes resultados, para que o desgaste não seja excessivo, o que provocaria alterações na forma do dente, o $\mathrm{HCl}$ a $18 \%$ pode ser aplicado no máximo por cinco vezes e, quando a pedra-pomes é adicionada, não ultrapassar quatro aplicações. Com o Prema pode-se fazer até 15 aplicações; com o ácido fosfórico a 37\%, no máximo sete e finalmente quando misturado à pedra-pomes, por até seis vezes. Na avaliação da textura superficial foram selecionados 50 incisivos inferiores humanos que apresentavam as superfícies vestibulares hígidas e os testes de rugosidade superficial foram feitos empregando o rugosímetro Hommel Tester T 1000. Os corpos-de-prova foram divididos em cinco grupos com dez espécimes cada um de acordo com o material empregado. A textura foi avaliada cinco vezes por corpo-de-prova de acordo com as seguintes condições: uma inicial, antes da realização do tratamento, as subseqüentes após 5, 10 e 15 aplicações de dez segundos dos compostos abrasivos, intercaladas, e a última após o polimento com disco Sof-Lex. A análise de variância, complementada pelo teste de Tuckey, mostrou que ocorreu uma diminuição na rugosidade após a realização dos tratamentos, com exceção do ácido fosfórico quando aplicado por cinco vezes; o polimento tornou todas as superfícies igualmente lisas. Para avaliação ao MEV foram selecionados 42 incisivos inferiores hígidos e sem defeitos no esmalte, os quais foram divididos aleatoriamente em 20 grupos, cada um constituído de dois dentes. No controle não foi realizado nenhum tratamento, e nos grupos restantes 5 , 10 e 15 aplicações dos compostos citados e também submetidos, após 15 aplicações, ao polimento com discos Sof-Lex. A presença do abrasivo promoveu o aparecimento de uma superfície mais lisa, na qual não se distingue a delimitação dos prismas de esmalte; com o polimento todas as superfícies apresentaram aspecto semelhante entre si; nenhum destes efeitos foi considerado como prejudicial para a condição final, especialmente porque o polimento equiparou todas as situações.

GULTZ et al $^{21}$, em outubro de 1999, observaram o efeito, no padrão morfológico superficial, de um condicionador ácido e de dois agentes 
clareadores indicados para uso em consultório: 1) Ultra-Etch (Ultradent Products, South Jordan, UT, à base de ácido fosfórico a 35\%; 2) Opalescence Quick (Ultradent Products, South Jordan, UT), à base de peróxido de carbamida a $35 \%$ e 3) Opalescence X-tra (Ultradent Products, South Jordan, UT), cujo ingrediente ativo é o peróxido de hidrogênio a 35\%. Todos os produtos foram aplicados de acordo com as recomendações do fabricante e seus efeitos sobre a superfície do esmalte dental analisadas por meio do microscópio eletrônico de varredura. Segundo os autores, não foram observadas alterações nos dentes clareados, quando comparados com o do grupo controle, sendo que o grupo que recebeu condicionamento com ácido fosfórico revelou significante diferença na superfície do esmalte quando comparado aos outros grupos.

SILVA E SOUZA ${ }^{55}$, em 1999 na sua dissertação de mestrado, demonstrou não haver diferenças estatisticamente significantes nos valores de infiltração marginal em restaurações de resina composta, em dentes previamente clareados com peróxido de hidrogênio a $30 \%$ associado ao perborato de sódio (na conhecida técnica de clareamento interno mediato) ou clareados com peróxido de carbamida a 10\% (produto empregado no clareamento externo), em relação ao grupo controle. Apesar disso, no grupo onde foi aplicado o peróxido de hidrogênio a 30\% puro no interior da câmara pulpar (técnica imediata de clareamento interno), houve maiores índices de infiltração que aqueles onde foram aplicadas outras técnicas de clareamento.

No mês de dezembro de 1999, McCASLIN et al. ${ }^{40}$ avaliaram as alterações de cor da dentina no clareamento vital com peróxido de carbamida e moldeira noturna, na tentativa de checar a mudança de cor na dentina e determinar se essa mudança era uniforme ou ocorria do exterior (junção amelodentinária) para o interior (cavidade pulpar). Doze dentes incisivos superiores foram seccionados inciso-cervicalmente no longo eixo mediano vestibular, sendo fixados em lâminas de vidro para microscopia e clareados com peróxido de carbamida a 10\% (Opalescence), pois as características de densidade e viscosidade desse material permitiram-no ser 
colocado diretamente sobre o esmalte, sem o auxílio de uma moldeira. Os dentes foram clareados com o citado produto comercial durante dez dias, ocasião onde foram mantidos dentro de um umidificador com umidade relativa de 100\%; diariamente o sol clareador era aplicado por oito horas, sendo que o mesmo era enxaguado após decorrido esse prazo; salientou-se que por tratar-se de um estudo laboratorial, os efeitos do material clareador poderiam ter sido minimizados em decorrência da ausência de saliva e outros materiais orgânicos que precipitam a reação de oxidação. Antes e após o tratamento clareador, todas as superfícies foram fotografadas em condições idênticas, levando-se em consideração cuidados como a não utilização de "flashes", distâncias e exposições padronizadas, filmes do mesmo lote e revelação dos mesmos simultaneamente, para minimizar variações no processo de obtenção das imagens. Os diapositivos coloridos foram "escaneados" e as imagens digitalizadas sofreram análise radiométrica da dentina utilizando o programa $\mathrm{NIH}$ (National Institute of Health) Image, que distribuiu 256 tons de cinza, desde o branco até o preto. A análise estatística mostrou um aumento significante no clareamento $(p=0,01)$ nas áreas internas e externas da dentina durante o clareamento, em comparação com as áreas controle, significando que esse aumento na claridade dentinária ocorreu de maneira uniforme, em vez de ocorrer do exterior para o interior.

SPALDING58, em 2000, avaliou "in vitro" o aspecto morfológico da superfície do esmalte e uma possível alteração na permeabilidade dental após tratamentos clareadores diversos. Para tanto, tal aspecto morfológico foi analisado por meio de microscopia eletrônica de varredura, após a aplicação de dois materiais clareadores utilizados nas técnicas de clareamento externo, em amostras de dentes irrompidos e não irrompidos. Os produtos selecionados foram o peróxido de hidrogênio a 35\% (Opalescence X-tra, Ultradent, South Jordan, UT) e o peróxido de carbamida a 10\% (Opalescence Regular 10\%, Ultradent, South Jordan, UT), empregados isoladamente e de maneira associada, ou seja, uma aplicação do Opalescence X-tra e subseqüentemente a complementação com o Opalescence Regular 10\%, com aplicações de 12 horas diárias durante uma 
semana. Seis pré-molares irrompidos e seis terceiros molares não irrompidos humanos foram seccionados longitudinalmente no sentido mesiodistal e vestibulolingual, de maneira que foram obtidos quatro fragmentos de cada dente. Três fragmentos de cada dente passaram pelos processos de clareamento a seguir: protocolo 1) tratamento com Opalescence X-tra, de acordo com as instruções do fabricante, que consistem em aplicação de 1 $\mathrm{mm}$ de espessura do gel clareador e fotoativação por dez minutos, em dois tempos de cinco minutos cada um; protocolo 2) tratamento idêntico ao protocolo 1, e armazenagem em saliva natural, à temperatura de $37^{\circ} \mathrm{C}$, durante um período de uma semana; a cada 12 horas os espécimes eram lavados e a saliva trocada; protocolo 3) idêntico ao protocolo 1 e com armazenagem em saliva por 24 horas, de acordo com o protocolo 2, mas houve a complementação com peróxido de carbamida por 12 hora diárias. Neste período, os espécimes eram mantidos a uma temperatura de $37^{\circ} \mathrm{C}$, em ambiente úmido, para evitar a desidratação. Nas 12 horas seguintes, os espécimes eram novamente imersos em saliva, simulando "in vitro" uma associação da técnica mista de clareamento dental, com a associação da técnica de consultório (peróxido de hidrogênio a 35\%) e a caseira (peróxido de carbamida a 10\%). A autora concluiu que, na análise comparativa do efeito dos materiais clareadores na superfície do esmalte dental humano, existe uma grande variação no padrão morfológico normal do esmalte; áreas alteradas observadas em alguns espécimes experimentais foram discretas, e que os materiais clareadores não provocaram um efeito característico peculiar. Concluiu ainda que os materiais testados conforme estabelecido neste estudo não trazem grandes implicações clínicas e que estudos adicionais avaliando outras propriedades do esmalte, após a utilização de materiais clareadores, tornam-se necessários.

Em novembro de 2000, JUNQUEIRA et al. ${ }^{30}$ avaliaram o efeito do peróxido de carbamida a 35\% sobre o esmalte dental humano, com o auxílio da microscopia eletrônica de varredura e da microscopia de luz polarizada. Foram utilizadas 32 amostras obtidas de pré-molares humanos, divididas em quatro grupos, onde os dois primeiros (A e B) eram os grupos 
experimentais, com dez amostras cada um e os dois últimos (C e D) foram denominados grupos controle, cada um com seis amostras; nos grupos experimentais foi efetuado condicionamento ácido com ácido fosfórico a 37\%, por 30 segundos, seguido de rinsagem e tratamento com peróxido de carbamida a $35 \%$ em gel, que foi aplicado em toda a face vestibular e lingual dos dentes, durante 30 minutos. Ao final dessa aplicação, os dentes foram lavados com um jato de água e o tratamento repetido novamente após os intervalos de sete e quatorze dias, totalizando três aplicações de peróxido de carbamida a $35 \%$, sendo que somente na primeira aplicação os dentes foram tratados com ácido fosfórico. Entre cada sessão de clareamento, os dentes do grupo A ficaram armazenados em água destilada, e os do grupo $B$, em saliva artificial, ambos em estufa a $37 \pm 1^{\circ} \mathrm{C}$; os dentes dos grupos controle não receberam nenhum tipo de tratamento e ficaram armazenados durante todo experimento em água destilada (Grupo C) ou em saliva artificial (Grupo D) a $37 \pm 1^{\circ} \mathrm{C}$. Os resultados evidenciaram que, no método de microscopia de luz polarizada (MLP), não foram observados escurecimentos na zona de subsuperfície do esmalte, indicando que não houve diferença na sua textura superficial quando foram comparados os grupos experimentais e controle; já à luz da microscopia eletrônica de varredura (MEV), as amostras dos grupos C e D (grupos experimentais), alterações ocorreram tanto nos dentes que ficaram imersos em água destilada quanto em saliva artificial. Segundo os autores, A MLP mostrou-se um método inadequado par avaliar alterações superficiais do esmalte após tratamento clareadores, sendo que a MEV revelou alterações morfológicas significantes no esmalte, quando a técnica de clareamento com peróxido de carbamida a 35\% foi empregada, havendo um aumento da porosidade e da rugosidade nos espécimes dos grupos experimentais, o que justificaria que os profissionais e pacientes deveriam ser orientados sobre os efeitos nocivos que os clareadores dentais podem causar no esmalte.

RIEHL, H. ${ }^{51}$, em 2001, disponibilizou um curso teórico completo sobre clareamento dental, dentro de uma tecnologia híbrida que mescla o recurso interativo da internet com o Cd-rom. O programa desse 
curso aborda os seguintes capítulos: 1) Etiologia das alterações de cor; 2) Química do clareamento dental; 3) Classificação dos agentes clareadores; 4) Clareamento de dentes vitais; 5) Clareamento de dentes não vitais; 6) Efeitos sobre a polpa; 7) Efeitos sobre o esmalte; 8) Reabsorção cervical externa e 9) Lesões em tecidos moles. No capítulo "efeitos sobre o esmalte" o autor discorre sobre o efeito dos diversos tipos de agentes clareadores sobre o esmalte dental superficial, fato que sempre preocupou a maioria dos clínicos e pesquisadores. Havia suspeitas de que os agentes clareadores pudessem promover a desmineralização do esmalte, colocando em dúvida se tais produtos eram ou não nocivos. Alguns produtos clareadores caseiros (peróxido de carbamida), por conterem quantidades traço de ácido em suas composições e, por isso, possuírem um pH levemente ácido $(6,5)$, levaram alguns pesquisadores a acreditar que os mesmos poderiam promover algum grau de desmineralização do esmalte. A justificativa disso deve-se ao fato da maior estabilidade dos peróxidos na presença de ácidos fracos (maleico, por exemplo) ou de pequenas quantidades de ácidos fortes (fosfórico, por exemplo). Clinicamente, esses produtos se decompõem, como por exemplo, o peróxido de carbamida (10 a $22 \%$ ) que, ao entrar em contato com os dentes e a saliva desdobra-se em peróxido de hidrogênio (3 a 7,5\%) e uréia (7 a 15,5\%), respectivamente. O peróxido de hidrogênio degrada-se em oxigênio nascente e água, enquanto que a uréia desdobra-se em amônia e dióxido de carbono; a presença da amônia como subproduto da reação, faz com que haja a elevação do $\mathrm{pH}$. O autor ainda revela sua teoria sobre o que aconteceria, hipoteticamente, com o esmalte superficial no momento da ação do clareamento. Levando-se em conta que o esmalte seria um tecido vivo (se adotarmos como critério de vida seu metabolismo), sabemos serem possíveis as trocas iônicas entre sua superfície e soluções contendo flúor. Um mecanismo parecido ocorre com o íon $\mathrm{O}^{-}$(oxigênio nascente), pois ele penetra pelos poros do esmalte alcançando a dentina e muitas vezes, em concentrações baixíssimas, a polpa. Quando tal íon está em quantidade exagerada, como é o caso de peróxidos potentes (de hidrogênio a 35\%) por períodos de tempo excessivamente longos, suspeita-se que ele não atuaria somente sobre as moléculas de pigmentos (fracamente ligadas ao esmalte e à dentina), agindo também de maneira pouco seletiva sobre as proteínas do 
esmalte, que compõe sua matriz. Havendo a degradação da matriz, que reveste cada prisma, estes prismas ficariam sem suporte e se fraturariam, originando uma imagem, à luz da microscopia eletrônica de varredura, composta de irregularidades que lembram o esmalte condicionado por ácido fosfórico. Isso comprovaria o que se observa clinicamente onde, com exagerado tempo de aplicação de potentes peróxidos, o esmalte perderia o brilho ao final do procedimento clareador e manteria essa aparência fosca por várias sessões clínicas. Mesmo após sessões de polimento com discos abrasivos e aplicação tópica de flúor o aspecto fosco permaneceria. Sugerese a adoção de substâncias clareadoras mais ou menos potentes, considerando o tempo de aplicação de cada tipo, pois o principal problema poderia ser o aparecimento e a manutenção de um esmalte poroso, o que acarretaria em novo e rápido manchamento extrínseco.

Em setembro de 2001, GONÇALVES; MONTE ALTO e RAMOS $^{20}$, com o propósito de avaliar alterações cromáticas e morfológicas no esmalte dental hígido, publicaram um estudo onde se empregou o peróxido de carbamida a 10\%, pelo intervalo de três semanas. Para tanto, cinco terceiros molares inclusos foram seccionados, originando vinte amostras das faces vestibular e lingual, das quais apenas quinze foram utilizadas; dez amostras foram posicionadas em dois dispositivos intra-orais de acrílico e utilizados por duas voluntárias; a primeira voluntária tratou externamente as cinco amostras durante oito horas noturnas e a segunda tratou as outras cinco amostras, também fora do ambiente bucal, por um período de 30 minutos diurnos; as outras cinco amostras serviram como controle. O tratamento foi feito com peróxido de carbamida manipulado por um período de três semanas, de maneira que os dispositivos permaneceram na cavidade bucal durante todo o período de tratamento, sendo removidos apenas na hora das refeições e durante o tratamento com o gel clareador, quando foram mantidos dentro de um pote plástico com tampa, forrado com gaze umedecida em água filtrada. Ao final desse período a cor das amostras foi registrada novamente, sendo possível constatar que em ambos os casos o efeito clareador foi significante, sendo diretamente proporcional ao maior 
tempo de uso. A análise ao MEV demonstrou alterações no esmalte dental em ambos os casos que receberam tratamento, com evidente aumento de porosidade da superfície tratada, em comparação com o controle, o que levou os autores a concluir que: 1) durante o período de tratamento proposto, em ambos os casos, o clareamento dental foi significativo; 2) o tratamento noturno proporcionou grau de clareamento mais evidente, provavelmente devido ao maior tempo de atuação do produto e 3) as fotomicrografias demonstraram padrão de desmineralização nas amostras tratadas, sendo proporcional ao maior tempo de ação do produto clareador. 
3 - Proposição 


\section{3 - PROPOSIÇÃO}

Em função da grande controvérsia observada na literatura com relação aos efeitos dos materiais clareadores nas superfícies dentárias, propusemos-nos a avaliar:

- os valores da dureza e da rugosidade da superfície de esmalte bovino tratado com três tipos diferentes de agentes clareadores;

- avaliar se a ameloplastia ácida (microabrasão) é capaz de recuperar a dureza e a lisura do esmalte, caso algum grupo apresentasse alterações. 


\section{4 - Materiais e métodos}




\section{4 - MATERIAIS E MÉTODOS}

Foram coletados ambos os dentes incisivos centrais inferiores de 30 bois, originários de um lote maior destes animais, os quais foram abatidos num conceituado abatedouro local ${ }^{\#}$; esta população era constituída de animais sadios, provenientes do cruzamento de diversas raças, com predominância do tipo designado Nelore (Bos Indicus), com idade média de 30 meses e peso por volta de 18 arrobas, que haviam sido criados num sistema denominado como de semi-confinamento, com rotação de pastagem; os 60 órgãos dentários citados constituíram a população amostral do presente experimento; todos os dentes foram extraídos imediatamente após o sacrifício dos animais, operação diária rotineira, efetuada no citado abatedouro, e armazenados em solução de timol a 0,1\%, contida num frasco de vidro de $500 \mathrm{ml}$, na qual ficavam completamente submersos.

O autor da presente investigação (único operador envolvido) recebia os dentes coletados (sempre extraídos pelo mesmo funcionário do referido abatedouro), cerca de 6 horas após as respectivas extrações, ocasião em que os raspava, em toda a extensão das superfícies radiculares, com uma cureta do tipo rotineiramente utilizado em procedimentos periodônticos, para remoção de tecidos moles, e submetia-os a uma profilaxia com escova tipo Robinson e pedra-pomes e água, sendo imediatamente devolvidos à solução de timol. Com o auxílio de um disco de diamante os dentes foram seccionados aproximadamente a $2 \mathrm{~mm}$ abaixo da junção amelocementária, expondo toda câmara pulpar, possibilitando a remoção de toda a polpa coronária, deixando praticamente apenas a coroa de cada elemento dental. Subseqüentemente eram analisados sob uma lupa estereoscópica para que fossem descartados os espécimes que

\footnotetext{
${ }^{\#}$ Frimondelli, Bauru - SP.
} 
apresentassem trincas. Dessa maneira, foram selecionados 40 dentes (coroas) que, para a realização dos testes propostos, foram posicionadas em matrizes circulares confeccionadas com silicona polimerizada por adição (RemaSil - Dentaurum - GmB), medindo $10 \mathrm{~mm}$ de altura e $25 \mathrm{~mm}$ de diâmetro e, dentro das mesmas, verteu-se resina epóxica. Teve-se o cuidado de manter a porção mais plana da face vestibular de cada coroa o mais paralelo possível da superfície do agora denominado corpo-de-prova.

Após a completa polimerização da resina epóxica, todos os 40 CP foram submetidos a um aplainamento da face vestibular exposta, já que a superfície do esmalte bovino apresenta periquimáceas extremamente numerosas e profundas, o que impossibilitaria o registro numérico da dureza e da rugosidade com seus respectivos dispositivos de leitura. Tal aplainamento foi realizado numa lixa circular, sob copiosa refrigeração, com discos de lixa, com granas em ordem decrescente de granulação: 320, 600 e 1500, sendo que a cada troca de lixa (grana), cada CP era abundantemente lavado visando a remoção de grânulos da lixa anterior. Após cada cinco CP abrasionados, o disco de lixa era substituído por um novo, o que se constituía numa garantia de superfície mais regular e uniforme entre os grupos. Após a aplicação da lixa de grana 1500, foi obtida uma superfície adamantina com uma grande lisura e um brilho especular em todos os CP. Um cuidado muito importante durante os procedimentos de abrasão dos CP foi que os mesmos foram posicionados de maneira que os incisivos inclusos dentro de cada disco de resina epóxica, mantivessem seu eixo imaginário cérvico-incisal o mais perpendicular possível do raio de rotação do disco de lixa.

Estando prontos, para cada um dos quatro tratamentos propostos, os $40 \mathrm{CP}$ foram divididos estabelecendo-se os quatro seguintes grupos de espécimes, cada qual com dez constituintes, como observamos na tabela 4.1: 
Tabela 4.1 - Grupos estabelecidos para cada um dos tratamentos.

\begin{tabular}{cc} 
Grupo & Tratamento \\
\hline $\mathrm{H}_{2} \mathrm{O}$ & $\mathrm{H}_{2} \mathrm{O}$ deionizada \\
$\mathrm{H}_{2} \mathrm{O}_{2}$ & $\mathrm{H}_{2} \mathrm{O}_{2} 35 \%$ \\
X-tra & Opalescence X-tra \\
Reg. & Opalescence Regular \\
\hline
\end{tabular}

No grupo $\mathrm{H}_{2} \mathrm{O}$, empregado como controle, a água deionizada utilizada era proveniente de um aparelho deionizador Permution, modelo 1800, fabricado por Permution Equipamentos e Produtos Químicos, Curitiba PR.

$\mathrm{O}$ peróxido de hidrogênio, utilizado no grupo $\mathrm{H}_{2} \mathrm{O}_{2}$, tinha qualidade p.a. ${ }^{\mathrm{b}}$, tendo sido fabricado por Labsynth Produtos para Laboratório Ltda., Diadema - SP, e embalado em frasco de vidro com $1000 \mathrm{ml}$ de capacidade, do lote número 28.129, com inscrições no respectivo rótulo informando ser $\mathrm{H}_{2} \mathrm{O}_{2}$, a $30-35 \%$, tendo um valor de $\mathrm{pH}$ aferido por volta de 1,8 e validade até abril de 2001 .

O produto Opalescence X-tra, empregado no grupo X-tra, é um produto clareador dentário, fabricado pela Ultradent Products Inc., South Jordan, UT - EUA, acondicionado na forma de um sol alaranjado, contido em seringas de 1,2 gramas, do lote $39 \mathrm{CD}$, cujo componente básico é o peróxido de hidrogênio a $35 \%$, com um $\mathrm{pH}$ aferido por volta de 4 , de acordo com informações contidas na bula e no perfil técnico do produto, e com prazo de validade até abril de 2000.

No grupo Reg, empregou-se o agente clareador Opalescence Regular, que é fabricado pela Ultradent Products Inc., South Jordan, UT EUA, embalado em seringas de 1,2 gramas, do lote 23DG, na forma de um sol transparente constituído de peróxido de carbamida a $10 \%$, à base de

${ }^{\mathrm{b}}$ Pró-análise, ou seja, de alta pureza, para fins de análise química. 
peróxido de carbamida a $10 \%$, extremamente viscoso e com um $\mathrm{pH}$ aferido de 6,5, e com prazo de validade impresso na embalagem de maio de 2000.

Todos os materiais utilizados foram mantidos em condições adequadas, para evitar sua alteração, seguindo-se os procedimentos rotineiros empregados em laboratórios de análise química e/ou as instruções dos respectivos fabricantes dos produtos utilizados.

Os líquidos e os produtos Opalescence X-tra e Opalescence Regular (sob a forma de creme, ou seja, de sol) foram medidos com o auxílio de uma pipeta (Pipetman, Laboratórios Gilson, França), graduada em décimos de mililitros e com capacidade de $10 \mathrm{ml}$.

Os valores de $\mathrm{pH}$ de todos os agentes clareadores acima mencionados foi aferido no Departamento de Bioquímica da Faculdade de Odontologia de Bauru, em pH-metro da marca Micronal, modelo B 371, fabricado por Micronal S/A, São Paulo - SP, com precisão de leitura de décimo da unidade própria, cuja calibração era feita com duas soluções eletrolíticas prontas para o uso, da marca Calisol (Micronal S/A, São Paulo $\mathrm{SP}$ ), respectivamente com $\mathrm{pH}$ de 4,0 (número de referência 1102) e 7,0 (número de referência 1103), ambas à $20^{\circ} \mathrm{C}$.

\section{Preparo dos dentes para a verificacão da dureza e rugosidade:}

Dez corpos-de-prova foram então distribuídos em cada um dos quatro grupos de estudos propostos, conforme a Tabela 4.1. Convém salientar que cada corpo-de-prova apresentava uma área plana exposta aproximada de $12 \times 8 \mathrm{~mm}\left(96 \mathrm{~mm}^{2}\right)$.

Os corpos-de-prova foram submetidos aos tratamentos a serem descritos obedecendo aos seguintes protocolos: 
Tabela 4.2 - Protocolo de aplicação dos agentes clareadores.

\begin{tabular}{ccccc} 
Substâncias & Natureza & Quantidade & Ativação & Tempo aplicação \\
\hline $\begin{array}{c}\mathrm{H}_{2} \mathrm{O} \\
\text { deionizada }\end{array}$ & líquida & $0,5 \mathrm{ml}$ & $\begin{array}{c}\text { luz incandescente } \\
\text { (calor) }\end{array}$ & $\begin{array}{c}2 \text { sessões de } 60 \\
\text { minutos cada } \\
\text { uma }\end{array}$ \\
$\mathrm{H}_{2} \mathrm{O}_{2}$ & líquida & $0,5 \mathrm{ml}$ & $\begin{array}{c}\text { luz incandescente } \\
\text { (calor) }\end{array}$ & $\begin{array}{c}2 \text { sessões de } 60 \\
\text { minutos cada } \\
\text { uma }\end{array}$ \\
X-tra & sol & $0,5 \mathrm{ml}$ & luz halógena & $\begin{array}{c}2 \text { sessões de 15 } \\
\text { minutos cada } \\
\text { uma. }\end{array}$ \\
Reg & sol & $0,5 \mathrm{ml}$ & enzimas salivares & $\begin{array}{c}7 \text { sessões de } 4 \\
\text { horas cada uma }\end{array}$ \\
\hline
\end{tabular}

Todos os tratamentos eram realizados sobre uma bancada de trabalho, em ambiente arejado e com todos os E.P.I. (equipamentos de proteção individual) disponíveis.

A água deionizada e o peróxido de hidrogênio a $35 \%$ eram mantidos sobre a porção exposta de esmalte do CP através de um pequeno pedaço de gaze, que recobria totalmente a área. Posicionada a 20 centímetros da superfície da referida gaze, estava uma lâmpada incandescente de 100 Watts, que fornecia luminosidade e calor $\left(60^{\circ} \mathrm{C}\right)$ para os líquidos testados, por 60 minutos cada um; a cada 15 minutos, tanto para a água deionizada quanto para o peróxido de hidrogênio a $35 \%$, novo pedaço de gaze era colocado e umedecido pela mesma quantia e tipo de líquido testado. Todo o processo foi repetido 24 horas depois.

O produto Opalescence X-tra foi depositado sobre a plataforma de esmalte e, imediatamente, à distância de um centímetro da superfície do sol clareador, irradiado por $1.100 \mathrm{~mW} / \mathrm{cm}^{2}$ de luz halógena (função "BLEACH"), provenientes de uma unidade fotopolimerizadora Optilux 501, da empresa norte-americana Demetron (SDS-Kerr, representada no Brasil pela Labordental) e aferidos através de radiômetro acoplado na carcaça do referido aparelho. Em cada uma das duas sessões foram efetuados 30 ciclos de luz, cada um com 30 segundos, totalizando 15 minutos 
de fotoativação, sendo que a cada 10 ciclos o sol clareador era agitado para manter-se uniforme a ação da energia luminosa em todo o seu volume.

O sol clareador à base de peróxido de carbamida a $10 \%$, Opalescence Regular, teve um método de aplicação totalmente diferente dos outros já descritos, pois sua indicação requer o uso de uma moldeira individual feita de plástico. As faces de prova dos dez CP constituintes desse grupo foram moldadas com alginato, e os respectivos moldes vazados, gerando 10 réplicas em gesso tipo IV (VelMix - SDS Kerr), que foi manipulado obedecendo a relação água/pó recomendada pelo fabricante do gesso e o tempo de espatulação de 1 minuto. Após 1 hora, os modelos foram removidos dos respectivos moldes e sobre a face de prova de cada modelo de gesso foi confeccionado um alívio em resina específica para esse fim (Block-Out, Ultradent Products - South Jordan, EUA), estendida pela mesma área da superfície exposta de esmalte e com espessura de 0,5 milimetro. Sobre a face de prova de cada CP, foi vertido uma lâmina de etilvinilacetato (EVA - Ultradent Products, South Jordan, EUA) aquecida num conformador a vácuo (VaccumForming - Ultradent Products, South Jordan, EUA); as "moldeiras individuais" eram adequadamente recortadas e ajustadas em seus respectivos $\mathrm{CP}$, estando prontas para receber o produto clareador. A quantia de 0,5 mililitros do sol Opalescence Regular foi dispensada dentro do espaço correspondente ao alívio feito anteriormente com resina e, antes da moldeira ser vertida sobre seu respectivo $\mathrm{CP}$, ao sol clareador era misturada à quantia de 0,5 mililitros de saliva humana "in natura", fresca, coletada por estimulação de um mesmo doador envolvido neste trabalho; depois de homogeneizada a mistura, a "moldeira individual" agora "carregada", era vertida por sobre seu respectivo $\mathrm{CP}$ e mantida em estufa a $37^{\circ} \mathrm{C}$ pelo período de 4 horas; foram efetuadas ao todo sete sessões como esta, simulando um tratamento clareador doméstico completo.

Durante todo o período em que não estavam sendo submetidos aos tratamentos descritos, todos os CP eram mantidos em saliva 
artificial", especificamente formulada para remineralização dos tecidos duros dentais; após as últimas sessões de cada grupo, os dentes eram lavados em água deionizada, secos naturalmente e logo em seguida, armazenados em estojos para transporte, a fim de realizarmos os testes de dureza e de rugosidade.

Ficou previamente estabelecido que, se houvesse diferença visível nos valores de dureza e de rugosidade, comparando-se a média aritmética inicial e final de cada grupo, os grupos com alteração, ou seja, uma suposta queda na dureza média e aumento de rugosidade, uma tentativa de recuperação da dureza e da rugosidade originais seria tentada através da adoção de uma única sessão de microabrasão, executada com o produto Opalustre. O Opalustre utilizado é um produto abrasivo para desgastar o esmalte, fabricado pela Ultradent Products Inc., South Jordan, UT - EUA, contido sob a forma de um sol lilás escuro em seringas de 1,2 cc, do lote de fabricação 33HM, cujos componentes básicos são o ácido hidroclorídrico a $6,6 \%$ e o carbeto de sílica (carborundo), compondo um sol solúvel em água, com prazo de validade até novembro de 2000.

Tal sessão de microabrasão obedeceu a metodologia do trabalho de MENDES $^{44}$, que aplicava o material abrasivo com o auxílio de uma taça de borracha integrante do conjunto comercial Opalustre adaptada ao contra-ângulo, que girou em baixa rotação, com a pressão do compressor regulada em 70 psi, empregando um micro-motor da marca Dabi-Atlante, que teve marcado em seu anel de regulagem de torque um ponto no local que determinava a menor velocidade desenvolvida, para que fosse constante. Durante a aplicação do Opalustre, o mesmo era aplicado sem pressão manual do contra-ângulo por sobre o CP, pois o braço do operador estava apoiado sobre a bancada de trabalho, sendo que a única pressão exercida era o peso do contra-ângulo. Os equipamentos de proteção individuais, como óculos, luvas, gorro foram empregados para evitar-se a ocorrência de acidentes desagradáveis, pois o Opalustre é corrosivo.

*Fórmula fornecida pela Profa ${ }^{\mathrm{a}}{ }^{\mathrm{a}}$ Olinda Tarzia. 
Após a aplicação do Opalustre, pelo tempo de 30 segundos em cada $\mathrm{CP}$, a superfície era lavada por 30 segundos com água deionizada e seca com ar comprimido por este mesmo período de tempo, aguardando o polimento final; tal polimento era feito com borrachas abrasivas Jiffy (Ultradent Products, South Jordan, Utah, EUA), nas cores amarela (granulação média) e branca (granulação fina), por 20 segundos cada uma.

Com todos os corpos-de-prova preparados, os testes de rugosidade foram os primeiros a serem efetuados $e$, posteriormente, os testes de dureza. O motivo principal dessa escolha é que o teste de medida de rugosidade não alteraria a superfície dos $\mathrm{CP}$, enquanto que o teste de dureza promoveria marcas oriundas da penetração da ponta de diamante, o que mais tarde poderia influenciar negativamente nos testes de rugosidade.

\section{1 - Teste de rugosidade}

O teste de rugosidade dos CP tratados, nas várias condições já descritas no texto, foi feita no Laboratório de Engenharia Mecânica, do Departamento de Engenharia Mecânica da Universidade Paulista "Júlio de Mesquita Filho" - UNESP, Campus de Bauru.

Para a averiguação da rugosidade superficial dos corpos-deprova já tratados com os agentes clareadores foi empregado um rugosímetro apropriado para tal finalidade, modelo Surtronic 3 Plus, código 112-1590, fabricado pela Taylor-Hobson, Inglaterra. Esse rugosímetro foi acoplado a um microcomputador, que analisava e emitia os dados das medidas efetuadas pelo referido rugosímetro.

O estudo da rugosidade leva em conta o valor da média aritmética de todas as distâncias absolutas do perfil de rugosidade traçado, ou seja, da área percorrida pelo sensor de varredura de superfície. Toda superfície apresenta um certo grau de rugosidade, de imperfeições, ou ainda de depressões e elevações, que podem ser aqui denominadas de "picos" e 
"vales", respectivamente para as porções mais elevadas e menos elevadas. Através da varredura (ou "escaneamento") e leitura sobre os corpos de prova, por meio de um sensor, obtém-se valores numéricos da rugosidade, em termos da rugosidade média $(\mathrm{Ra})$.

A média de rugosidade ( $\mathrm{Ra}$ ) de cada leitura feita pelo rugosímetro, é definida como o valor médio do perfil percorrido pelo sensor do aparelho sobre a superfície da amostra. A ponta desse sensor percorre a superfície previamente delimitada e seus movimentos verticais são convertidos em um sinal elétrico, emitido então ao microcomputador. Diferentes geometrias de superfície podem produzir valores de rugosidade média idênticos, prejudicando uma análise mais apurada dos resultados. Para diminuir esta possibilidade, deve-se utilizar um filtro elétrico ("cut-off") que elimine a detecção de irregularidades acima de seu limiar; neste estudo o rugosímetro foi ajustado para atuar com um "cut-off" de $0,25 \mu \mathrm{m}$, indicado para a medição de superfícies polidas e ou levemente abrasionadas. A ponta do rugosímetro percorreu $1,2 \mathrm{~mm}$ em cada leitura efetuada, no mesmo sentido (cérvico-incisal) para as três leituras e em todos os corpos-de-prova avaliados, sendo este determinado por uma linha imaginária paralela a partir da face plana de cada CP. Todos os valores obtidos, expressos em nanômetros, foram anotados em planilha própria e analisados estatisticamente para a comparação dos níveis de rugosidade observados, para mensuração dos possíveis efeitos dos tratamentos clareadores.

\section{2 - Teste de dureza}

Os testes de dureza foram realizados no Laboratório do Departamento de Dentística, Endodontia e Materiais Dentários da Universidade de São Paulo, Campus de Bauru, nos mesmos corpos-de-prova utilizados para os testes de rugosidade. 
Para a medida da dureza Vickers, foi empregada uma máquina específica para tal finalidade, denominada máquina para teste de dureza M Testor, Otto Wolpert-Werke, fabricada na Alemanha.

Ao estudarmos a dureza Vickers, podemos defini-la como a resistência oferecida pelos sólidos à penetração de uma ponta, em condições bem definidas nas Normas atualmente existentes. Consiste em pressionar um penetrador de diamante (em forma de uma pirâmide regular com base quadrada e ângulo de vértice de $136^{\circ}$ ) contra um corpo-de-prova; a força de ensaio $(F)$ e sua duração devem ser previamente escolhidas; a intensidade da força aplicada dividida pela área da impressão (ou marca) resultante expressa a resistência à penetração de um determinado corpo de prova, o que normalmente gera numa marca quadrada, onde a medida da diagonal desse quadrado corresponde a um número que, comparado a uma tabela própria (Härtetabellen, Wolpert), na página referente à carga de 300 gramas, resulta em um número conhecido como Número de Dureza Vickers.

Para os ensaios deste trabalho foi escolhida uma força de 300 gramas, que incidia sobre cada corpo-de-prova pelo tempo de 5 minutos; em cada corpo-de-prova foram realizadas três medições, respeitando-se a distância mínima de $1 \mathrm{~mm}$ entre uma marca e outra e evitando-se as áreas periféricas do esmalte. Neste equipamento de precisão, cada corpo-de-prova foi posicionado com sua face-de-prova voltada para baixo, centralizada sobre um orifício por onde o diamante percorrerá seu trajeto. A alavanca maior é puxada, conferindo uma pré-carga de 100 gramas, segundo orientação do fabricante, para padronizar as condições do ensaio, eliminando o efeito de possíveis irregularidades, a fim de que estas não alterassem o resultado final. Era então liberada uma alavanca menor, a qual permitia a aplicação da carga escolhida sobre a superfície em questão, pelo tempo necessário para que o diamante executasse sua marca. Passados o tempo de cinco minutos, a primeira alavanca era voltada à sua posição inicial, o que permitia que o corpo-de-prova pudesse ser visualizado pela lente, cujo foco era ajustado 
pelos parafusos micrométricos, e a aferição da diagonal pudesse ser medida e posteriormente comparados à citada tabela.

Os resultados foram anotados em ficha apropriada e as médias aritméticas de cada uma das três medições, submetidas à análise estatística. 


\section{5 - Resultados}




\section{5 - RESULTADOS}

\section{1 - Referentes aos ensaios de dureza}

Os resultados originais obtidos nos testes de dureza, descritos no capítulo anterior, estão apresentados na tabela 5.1 .1 e no gráfico 5.1.2 abaixo, assim como as respectivas médias e desvios-padrão.

Tabela 5.1.1 -Valores obtidos (Número de Dureza Vickers) para os espécimes das diversas condições estudadas, com suas médias $(m)$ e desvios-padrão $(\mathrm{dp})$, referentes aos testes de dureza. A expressão final, para todos os materiais, tem o mesmo significado; entretanto, a sigla Amelo (referente a ameloplastia efetuada nas condições descritas no texto) somente existiu para os materiais $\mathrm{H}_{2} \mathrm{O}_{2} 35 \%$ e Opalescence X-tra.

\begin{tabular}{|c|c|c|c|c|c|c|c|c|c|c|}
\hline & \multicolumn{10}{|c|}{ Condições } \\
\hline & \multicolumn{2}{|c|}{$\mathrm{H}_{2} \mathrm{O}$ destilada } & \multicolumn{3}{|c|}{$\mathrm{H}_{2} \mathrm{O}_{2} 35 \%$} & \multicolumn{3}{|c|}{ Opalescence X-tra } & \multicolumn{2}{|c|}{$\begin{array}{l}\text { Opalescence } \\
\text { Regular }\end{array}$} \\
\hline & inicial & final & inicial & final & Amelo & inicial & Final. & Amelo. & inicial & final \\
\hline 1 & 263 & 254 & 258 & 177 & 256 & 264 & 217 & 263 & 263 & 258 \\
\hline $\begin{array}{l}2 \\
3\end{array}$ & $\begin{array}{l}253 \\
262\end{array}$ & $\begin{array}{l}260 \\
262\end{array}$ & $\begin{array}{l}261 \\
255\end{array}$ & $\begin{array}{l}173 \\
170\end{array}$ & $\begin{array}{l}254 \\
256\end{array}$ & $\begin{array}{l}264 \\
251\end{array}$ & $\begin{array}{l}217 \\
219\end{array}$ & $\begin{array}{l}275 \\
256\end{array}$ & $\begin{array}{l}260 \\
260\end{array}$ & $\begin{array}{l}263 \\
260\end{array}$ \\
\hline 4 & 257 & 255 & 254 & 173 & 265 & 252 & 202 & 265 & 263 & 258 \\
\hline 5 & 272 & 272 & 260 & 174 & 252 & 260 & 218 & 260 & 252 & 257 \\
\hline 6 & 262 & 260 & 262 & 176 & 273 & 253 & 210 & 262 & 260 & 252 \\
\hline 7 & 254 & 258 & 253 & 173 & 269 & 277 & 202 & 258 & 264 & 258 \\
\hline 8 & 251 & 254 & 255 & 174 & 264 & 250 & 219 & 275 & 258 & 263 \\
\hline 9 & 261 & 260 & 254 & 171 & 262 & 271 & 216 & 257 & 254 & 260 \\
\hline 10 & 257 & 254 & 255 & 167 & 263 & 255 & 211 & 256 & 269 & 265 \\
\hline $\mathbf{x}$ & 259,20 & 258,90 & 256,70 & 172,80 & 261,40 & 259,70 & 213,10 & 262,70 & 260,30 & 259,40 \\
\hline$d p$ & 6,14 & 5,50 & 3,26 & 2,89 & 6,80 & 9,18 & 6,60 & 7,14 & 4,92 & 3,71 \\
\hline
\end{tabular}




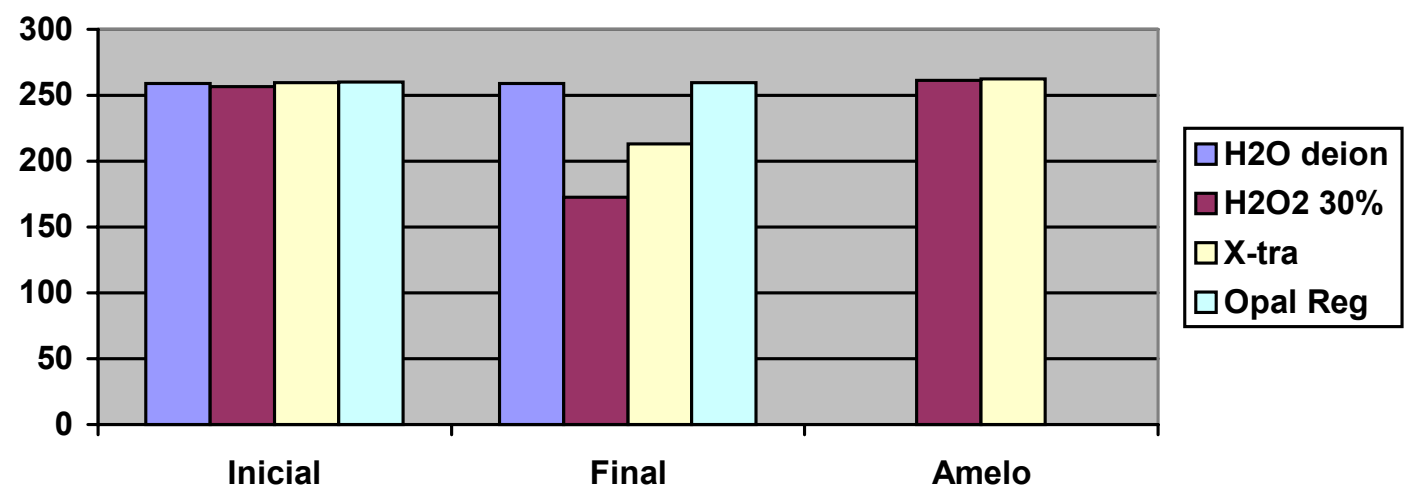

Gráfico 5.1.2 - O gráfico ilustra as médias dos valores originais obtidos nos testes de dureza.

Os resultados da análise de variância, aplicados às diferenças dos valores das colunas inicial e final da tabela 5.1.1, para todos os materiais, são apresentados na tabela 5.1.3:

Tabela 5.1.3 - Resultados da análise de variância para comparação entre as condições.

\begin{tabular}{ccccccc}
$\begin{array}{c}\text { graus de } \\
\text { liberdade do } \\
\text { efeito }\end{array}$ & $\begin{array}{c}\text { quadrado médio } \\
\text { do efeito }\end{array}$ & $\begin{array}{c}\text { graus de } \\
\text { liberdade do erro }\end{array}$ & $\begin{array}{c}\text { quadrado } \\
\text { médio do erro }\end{array}$ & F & Probabilidade \\
\hline 3 & 16251,49 & 36 & 52,67500 & 308,5238 & $0,001^{*}$ \\
\hline * - Estatisticamente significante $(p<0,05)$. & &
\end{tabular}

Levando-se em conta que a análise de variância apontou a existência de diferença significante aplicou-se o teste de Tukey-Kramer aos citados valores obtidos, cujos resultados podem ser encontrados na tabela 5.1.4:

Tabela 5.1.4 -Resultados do teste de Tukey-Kramer aplicado às diferenças observadas entre os valores, das colunas inicial e final, da tabela 5.1.1

\begin{tabular}{cc} 
Condição & Variação média \\
\hline $\mathrm{H}_{2} \mathrm{O}_{2}$ & $-83,9000$ \\
$\mathrm{X}$-tra & $-46,6000$ \\
$\mathrm{Reg}$ & $-0,9000$ \\
$\mathrm{H}_{2} \mathrm{O}$ & $-0,3000$ \\
\hline
\end{tabular}

Grupos unidos por barra vertical não possuem diferença estatisticamente significante entre si. 
Também foram feitas comparações (para amostras dependentes) individualmente para cada condição, aplicando-se o teste "t" pareado, cujos resultados aparecem na tabela 5.1.5

Tabela 5.1.5 - Para todas as condições foi feita a comparação entre as fases inicial e final, por meio do teste "t" pareado e este mostrou diferença estatisticamente significante nos grupos $\mathrm{H}_{2} \mathrm{O}_{2}$ e X-tra

\begin{tabular}{|c|c|c|c|c|c|c|c|}
\hline \multirow[t]{2}{*}{ Condição } & \multicolumn{2}{|c|}{ inicial } & \multicolumn{2}{|c|}{ final } & \multirow{2}{*}{$\begin{array}{c}\text { Diferença } \\
\text { média }\end{array}$} & \multirow[t]{2}{*}{$\mathbf{t}$} & \multirow[t]{2}{*}{$p$} \\
\hline & $x$ & $d p$ & $x$ & $d p$ & & & \\
\hline $\mathrm{H}_{2} \mathrm{O}$ dest. & 259,20 & 6,14 & 258,90 & 5,51 & 0,30 & 0,216 & $0,833 \mathrm{~ns}$ \\
\hline $\mathrm{H}_{2} \mathrm{O}_{2}$ & 256,70 & 3,26 & 172,80 & 2,89 & 83,90 & 86,383 & 0,000 * \\
\hline X-tra & 259,70 & 9,18 & 213,10 & 6,60 & 46,60 & 11,873 & 0,000 * \\
\hline Reg & 260,30 & 4,92 & 259,40 & 3,71 & 0,90 & 0,536 & $0,604 \mathrm{~ns}$ \\
\hline
\end{tabular}

Os resultados da análise de variância para comparação entre os quatro grupos, levando em conta as diferenças entre as fases final e inicial para as condições $\mathrm{H}_{2} \mathrm{O}$ e Opal Reg e as diferenças entre as fases amelo e inicial para as condições $\mathrm{H}_{2} \mathrm{O}_{2}$ e Opal-Xtra mostrou não haver diferença estatisticamente significante (Tabela 5.1.6).

Tabela 5.1.6 - Resultados da análise de variância para variáveis independentes.

\begin{tabular}{cccccc}
$\begin{array}{c}\text { graus de liberdade } \\
\text { do efeito }\end{array}$ & $\begin{array}{c}\text { quadrado médio } \\
\text { do efeito }\end{array}$ & $\begin{array}{c}\text { graus de } \\
\text { liberdade do erro }\end{array}$ & $\begin{array}{c}\text { quadrado } \\
\text { médio do erro }\end{array}$ & F & Probabilidade \\
\hline 3 & 31.266 & 36 & 35.383 & 0.8836 & 0.458751 ns \\
\hline
\end{tabular}

Tabela 5.1.7 - Para as condições $\mathrm{H}_{2} \mathrm{O}_{2}$ e X-tra foi feita a comparação entre as fases final e amelo, por meio do teste "t" pareado e este mostrou diferença estatisticamente significante nos grupos

\begin{tabular}{|c|c|c|c|c|c|c|c|}
\hline \multirow{2}{*}{ Condição } & \multicolumn{2}{|c|}{ final } & \multicolumn{2}{c|}{ amelo } & \multirow{2}{*}{$\begin{array}{c}\text { Diferença } \\
\text { média }\end{array}$} & \multirow{2}{*}{$\mathrm{t}$} & \multirow{2}{*}{} \\
\cline { 2 - 7 } & $\mathrm{x}$ & $\mathrm{dp}$ & $\mathrm{x}$ & $\mathrm{dp}$ & & \\
\hline $\mathrm{H}_{2} \mathrm{O}_{2}$ & 172,80 & 2,89 & 261,40 & 6,80 & $-88,60$ & $-38,837$ & 0,000 * \\
\hline X-tra & 213,10 & 6,60 & 262,70 & 7,14 & $-49,60$ & $-18,282$ & 0,000 * \\
\hline
\end{tabular}

* - Diferença estatisticamente significante $(p<0,05)$ 


\section{2 - Referentes aos ensaios de rugosidade}

Os resultados originais obtidos nos testes de rugosidade, descritos no capítulo anterior, estão apresentados na tabela 5.2.1 e no gráfico 5.2.2 abaixo, assim como as respectivas médias e desvios-padrão.

Tabela 5.2.1 - Valores obtidos (Ra) para os espécimes das diversas condições estudadas, com suas médias $(m)$ e desvios-padrão $(d p)$, referentes aos testes de rugosidade. A expressão final, para todos os materiais, tem o mesmo significado; entretanto, a sigla Amelo (referente a ameloplastia efetuada nas condições descritas no texto) somente existiu para os materiais $\mathrm{H}_{2} \mathrm{O}_{2} 35 \%$ e Opalescence X-tra.

\begin{tabular}{|c|c|c|c|c|c|c|c|c|c|c|}
\hline & \multicolumn{10}{|c|}{ Condições } \\
\hline & \multicolumn{2}{|c|}{$\mathrm{H}_{2} \mathrm{O}$ destilada } & \multicolumn{3}{|c|}{$\mathrm{H}_{2} \mathrm{O}_{2} 35 \%$} & \multicolumn{3}{|c|}{ Opalescence X-tra } & \multicolumn{2}{|c|}{$\begin{array}{c}\text { Opalescence } \\
\text { Reg }\end{array}$} \\
\hline & inicial & final & inicial & final & Amelo & inicial & final & Amelo & inicial & final \\
\hline 1 & 58,7 & 59,5 & 57,06 & 404,00 & 84,66 & 56,06 & 364,33 & 54,76 & 56,03 & 57,43 \\
\hline 2 & 64,2 & 63,5 & 53,3 & 424,33 & 88,1 & 56,6 & 237,00 & 51,73 & 59,26 & 54,53 \\
\hline 3 & 64,9 & 62,3 & 54,9 & 286,66 & 83,73 & 56,8 & 248,66 & 59,2 & 56,06 & 64,23 \\
\hline 4 & 53,1 & 55,33 & 59,5 & 614,66 & 78,23 & 63,9 & 281,33 & 47,8 & 53,93 & 55,96 \\
\hline 5 & 52,07 & 58,3 & 66,03 & 393,33 & 83,83 & 57,8 & 162,33 & 51,8 & 56,4 & 50,96 \\
\hline 6 & 59,73 & 55,6 & 89,5 & 310,66 & 84,7 & 86,7 & 269,00 & 45,83 & 54,56 & 63,50 \\
\hline 7 & 56,8 & 57,25 & 57,4 & 479,33 & 84,6 & 58,8 & 299,33 & 43,83 & 57,9 & 62,03 \\
\hline 8 & 55,2 & 59,7 & 61,1 & 255,66 & 84,86 & 56,1 & 570,33 & 45,63 & 53,33 & 63,30 \\
\hline 9 & 58,3 & 57,8 & 69,7 & 377,00 & 82,8 & 57,7 & 215,66 & 50,96 & 58,13 & 58,43 \\
\hline 10 & 61,05 & 60,3 & 61,03 & 451,00 & 83,56 & 55 & 173,66 & 59,36 & 58,76 & 54,70 \\
\hline $\mathbf{x}$ & 58,40 & 58,95 & 62,95 & 399,66 & 83,90 & 60,54 & 282,16 & 51,09 & 56,43 & 58,50 \\
\hline dp & 4,29 & 2,65 & 10,55 & 104,25 & 2,44 & 9,51 & 117,36 & 5,47 & 2,05 & 4,57 \\
\hline
\end{tabular}



Gráfico 5.2.2 - O gráfico ilustra as médias dos valores originais obtidos nos testes de rugosidade. 
Os resultados da análise de variância, aplicados às diferenças dos valores das colunas inicial e final da tabela 5.2.1, para todos os materiais, são apresentados na tabela 5.2.3:

Tabela 5.2.3 - Resultados da análise de variância para comparação entre as condições.

\begin{tabular}{cccccc}
$\begin{array}{c}\text { graus de } \\
\text { liberdade do } \\
\text { efeito }\end{array}$ & $\begin{array}{c}\text { quadrado } \\
\text { médio do efeito }\end{array}$ & $\begin{array}{c}\text { graus de } \\
\text { liberdade do } \\
\text { erro }\end{array}$ & $\begin{array}{c}\text { quadrado } \\
\text { médio do } \\
\text { erro }\end{array}$ & F & Probabilidade \\
\hline 3 & 279420,7 & 36 & 6416,90 & 43,54 & $\mathbf{0 , 0 0 0 *}$ \\
* - Estatisticamente significante $(p<0,05)$. & & &
\end{tabular}

Levando-se em conta que a análise de variância apontou a existência de diferença significante aplicou-se o teste de Tukey-Kramer aos citados valores obtidos, cujos resultados podem ser encontrados na tabela 5.2.4:

Tabela 5.2.4 -Resultados do teste de Tukey-Kramer aplicado às diferenças observadas entre os valores, das colunas inicial e final, da tabela 5.2.1

$\begin{array}{cc}\text { Condição } & \text { Variação média } \\ \mathrm{H}_{2} \mathrm{O}_{2} & 336,7110 \\ \mathrm{X} \text {-tra } & 221,6170 \\ \mathrm{Reg} & 2,0710 \\ \mathrm{H}_{2} \mathrm{O} & 0,5530\end{array}$

Grupos unidos por barra vertical não possuem diferença estatisticamente significante entre si.

Também foram feitas comparações (para amostras dependentes) individualmente para cada condição, aplicando-se o teste "t" pareado, cujos resultados aparecem na tabela 5.2.5. 
Tabela 5.2.5 - Para todas as condições foi feita a comparação entre as fases inicial e final, por meio do teste " $t$ " pareado e este mostrou diferença estatisticamente significante nos grupos $\mathrm{H}_{2} \mathrm{O}_{2}$ e X-tra

\begin{tabular}{|c|c|c|c|c|c|c|c|}
\hline \multirow[t]{2}{*}{ Condição } & \multicolumn{2}{|c|}{ inicial } & \multicolumn{2}{|c|}{ final } & \multirow{2}{*}{$\begin{array}{c}\text { Diferença } \\
\text { média }\end{array}$} & \multirow[t]{2}{*}{$\mathbf{t}$} & \multirow[t]{2}{*}{$\mathbf{p}$} \\
\hline & $x$ & $d p$ & $x$ & $d p$ & & & \\
\hline $\mathrm{H}_{2} \mathrm{O}$ dest. & 58,40 & 4,29 & 58,95 & 2,65 & $-0,553$ & $-0,562$ & 0,5874 ns \\
\hline $\mathrm{H}_{2} \mathrm{O}_{2}$ & 62,95 & 10,55 & 399,66 & 104,25 & 336,71 & $-9,875$ & 0,0000 * \\
\hline X-tra & 60,54 & 9,51 & 282,16 & 117,36 & $-221,61$ & $-5,923$ & 0,0000 * \\
\hline Reg & 56,43 & 2,05 & 58,50 & 4,57 & $-2,07$ & $-1,144$ & $0,2820 \mathrm{~ns}$ \\
\hline
\end{tabular}

Os resultados da análise de variância para comparação entre os quatro grupos, levando em conta as diferenças entre as fases final e inicial para as condições $\mathrm{H}_{2} \mathrm{O}$ e Opal Reg e as diferenças entre as fases amelo e inicial para as condições $\mathrm{H}_{2} \mathrm{O}_{2}$ e OpalX-tra mostrou haver diferença estatisticamente significante (Tabela 5.2.6).

Tabela 5.2.6 -Resultados da análise de variância para variáveis independentes.

\begin{tabular}{ccccccc} 
efeito & $\begin{array}{c}\text { Efeito dos } \\
\text { graus de } \\
\text { liberdade }\end{array}$ & $\begin{array}{c}\text { Efeito do } \\
\text { quadrado } \\
\text { médio }\end{array}$ & $\begin{array}{c}\text { Erro dos } \\
\text { graus de } \\
\text { liberdade }\end{array}$ & $\begin{array}{c}\text { Erro do } \\
\text { quadrado } \\
\text { médio }\end{array}$ & F & Probabilidade \\
\hline 1 & $3^{*}$ & $2051.407^{*}$ & $36^{*}$ & $15.969^{*}$ & $128.455^{*}$ & $0^{2000000^{*}}$ \\
\hline${ }^{*}$ diferença estatisticamente significante & & &
\end{tabular}

Levando-se em conta que a análise de variância apontou a existência de diferença significante aplicou-se o teste de Tukey-Kramer aos citados valores obtidos, cujos resultados podem ser encontrados na tabela Tabela 5.2.7: 
Tabela 5.2.7 - Resultados do teste de Tukey-Kramer aplicado às diferenças observadas entre os valores, das colunas final e amelo, da tabela 5.2.6

\begin{tabular}{cc} 
Condição & Variação média \\
\hline $\mathrm{H}_{2} \mathrm{O}_{2}$ & 83,90 \\
X-tra & 51,09 \\
Reg & 58,50 \\
$\mathrm{H}_{2} \mathrm{O}$ & 58,95 \\
\hline
\end{tabular}

Grupos unidos por barra vertical não possuem diferença estatisticamente significante entre si.

Também foram feitas comparações (para amostras dependentes) individualmente para cada condição, aplicando-se o teste " $\mathrm{t}$ " pareado, cujos resultados aparecem na tabela 5.2.8.

Tabela 5.2.8 - Para as condições $\mathrm{H}_{2} \mathrm{O}_{2}$ e X-tra foi feita a comparação entre as fases final e amelo, por meio do teste "t" pareado e este mostrou diferença estatisticamente significante nos grupos

\begin{tabular}{rccccccc} 
Condição & \multicolumn{2}{c}{ final } & \multicolumn{2}{c}{ amelo } & Diferença & $t$ & $\mathrm{t}$ \\
& $\mathrm{x}$ & $\mathrm{dp}$ & $\mathrm{x}$ & $\mathrm{dp}$ & média & & \\
\hline $\mathrm{H}_{2} \mathrm{O}_{2}$ & 399,66 & 104,25 & 83,90 & 2,44 & 315,75 & 9,456 & 0,0000 * \\
X-tra & 282,16 & 117,36 & 51,09 & 5,47 & 231,07 & 6,092 & 0,0000 * \\
\hline
\end{tabular}

* - Diferença estatisticamente significante $(p<0,05)$ 
6 - Discussão 


\section{6 - DISCUSSÃO}

\section{1 - Considerações gerais}

O estudo do efeito de peróxidos sobre os dentes data de meados do século $X \mid X^{5,15,22,23,31,32,33,67}$ e $X X^{1,17}$, com um desenvolvimento acelerado no final dos anos $80^{24}$ e início dos anos $90^{25-28,35,36}$. Em 1889, Edward C. Kirk ${ }^{33}$ descreveu, possivelmente pela primeira vez, os prováveis mecanismos químicos do clareamento dental. Em seu trabalho ele afirmou que o sucesso do clareamento dental está na destruição dos pigmentos que afetam as estruturas dentais, por um agente químico suficientemente capaz para esse propósito. Ele classificou as substâncias clareadoras em duas classes: as oxidantes e as redutoras. As primeiras destroem o pigmento pela remoção do hidrogênio; as segundas o fazem pela remoção do oxigênio. Dentre as substâncias oxidantes, ele cita o peróxido de hidrogênio, o cloro e o permanganato de potássio reduzido pelo ácido oxálico, pois se assim não o fosse, seu produto final seria marrom. $O$ autor descreve seu método de clareamento, baseado na liberação de ácido sulfúrico, pela reação de sulfito de sódio (100 gramas) com ácido bórico (70 gramas). Essa mistura era preparada, colocada na câmara pulpar e adicionava-se uma gota de água, fechando-se imediatamente a cavidade com guta-percha. Os resultados foram gratificantes, acontecendo o clareamento segundo o autor, mais rapidamente do que quando se usava o cloro.

O real acontecimento, do ponto de vista químico, que propicia a reação de clareamento das estruturas dentais ainda não está completamente esclarecido, mas é certo que o poder de oxidação dos íons hidroxila $\left(\mathrm{OH}^{-}\right)$e dos íons oxigênio nascente $\left(\mathrm{O}^{-}\right)$, que se aproveitam do sistema de condução do esmalte e da dentina, por osmose, para alcançar os 
pigmentos cromatogênicos, desmembrando-os em compostos mais simples e de cor mais clara. Os pigmentos orgânicos, como a hemoglobina e restos necróticos de tecido pulpar, geralmente contêm anéis de carbono que são oxidados a compostos duplos de carbono e, posteriormente em grupos hidroxila. Já os pigmentos inorgânicos, como os provenientes de materiais de obturação de condutos radiculares e os sais de tetraciclina já apresentam reações de simplificação molecular desconhecida quando em contato com os agentes clareadores. Os processos de oxidação continuam ocorrendo até que seja atingido o que chamamos de "ponto de saturação", que é o ponto máximo de clareamento teoricamente sem prejuízo às estruturas dentais.

Mas... O que realmente acontece realmente durante 0 processo clareador?

Podemos, a partir de conhecimentos prévios adquiridos em histofisologia ${ }^{61}$ dental, bioquímica do esmalte ${ }^{46,43,52,53}$ e da dentina ${ }^{46,52,53,66}$ e também de conhecimentos de química ${ }^{7,39,42}$, ousar lançar algumas hipóteses sobre o que acreditamos acontecer quando os peróxidos de hidrogênio ou de carbamida banham as estruturas dentais, dentro das condições técnicas preconizadas para a realização do procedimento clareador.

O esmalte é considerado uma substância permeável. É constituído de $96 \%$ de fosfato de cálcio cristalino, hidroxiapatita e vestígios de íons flúor, magnésio e chumbo, aderidos a hidroxiapatita ${ }^{58}$. Seus cristais são entremeados por uma fina malha de material orgânico, geralmente proteínas insolúveis e peptídeos, além de uma pequena porcentagem de água ${ }^{61}$. esmalte comporta-se como uma membrana semi-permeável, possibilitando o trânsito de água e substâncias de pequeno peso molecular, como por exemplo os peróxidos de carbamida e de hidrogênio, por entre seus poros. Esse "sistema de condução" pode explicar alguns fenômenos físico-químicos que ocorrem na superfície do esmalte quando um procedimento clareador ou uma aplicação tópica de flúor são realizados. 
Acredita-se que o oxigênio nascente penetre nas estruturas mineralizadas do dente, inicialmente por osmose, pois a concentração desse íon $\left(\mathrm{O}^{-}\right)$externamente é grande. Quando as concentrações de oxigênio nascentes externa e internas se igualam, o trânsito desse íon permanece lento, no sentido produto clareador-dente, à medida que os íons que estão dentro da estrutura dental combinam-se com os pigmentos, oxidando-os.

Para iniciarmos a exposição da nossa hipótese, tomemos como pontos de partida os fatos de que o esmalte em condições normais apresenta-se altamente hidratado, mas que pode se desidratar em poucos minutos quando submetido a jatos de ar ou em contato com substâncias anidras; e também de que os pigmentos encontram-se ligados à matriz orgânica do esmalte e da dentina, dificilmente sendo encontrados na porção mineral desses tecidos. É conveniente também, nesse momento, definir alguns termos descritos parcialmente nos trabalhos de LLOYD $^{18}$ e RIEHL ${ }^{50}$, ${ }^{51}$, que são tensão oxidativa e potencial oxidativo, pois os mesmo serão empregados mais adiante:

1) Denomina-se tensão oxidativa ou estresse oxidativo o efeito observado em determinado substrato, como o esmalte, o tecido periodontal, o tecido gengival, ou quaisquer outros que tenham entrado em contato com o oxigênio nascente, durante um período de tempo conhecido. Baseado nos efeitos que esse substrato apresentará após esse contato, podemos ter o conhecimento se tal episódio gerou um dano estrutural (por exemplo, um alto estresse oxidativo oriundo de uma substância de alto potencial oxidativo) ou não.

2) Potencial oxidativo foi o nome encontrado para designar a potência das substâncias clareadoras; quanto maior for sua potência, conseqüentemente maior será seu potencial oxidativo. A potência oxidativa de uma substância clareadora é medida pela quantia e pela velocidade de liberação do oxigênio nascente, sendo estas dependentes de vários fatores, como a natureza do peróxido, sua concentração, temperatura em que se dá a 
reação e se há presença de íons metálicos, variação de pH ou de enzimas, que atuariam como catalisadoras.

Para as condições de clareamento mais popularizadas atualmente, que são os denominados tratamentos clareadores "de consultório" e "caseiro", podemos supor que ocorra o seguinte mecanismo de reação:

CLAREAMENTO DE CONSULTÓRIO: a solução do peróxido de hidrogênio a $30-35 \%(34 \mathrm{~g} / \mathrm{mol})$ é depositada sobre o esmalte dental, sendo ativada de acordo com o sistema clareador empregado, por calor ou por radiação luminosa (incluindo aí a radiação proveniente dos aparelhos de LASER). Uma vez decomposto em água e em oxigênio nascente, este último começa a penetrar rapidamente através dos poros do esmalte, trafegando também através da matriz orgânica do esmalte e da dentina. O oxigênio nascente reagiria prontamente com os pigmentos, possivelmente fazendo com que as fracas ligações entre as moléculas cromatógenas e a matriz orgânica sejam rompidas; tais moléculas continuariam a ser oxidadas pelos íons de oxigênio nascente que continuariam penetrando pelas estruturas dentais, tornando-as menores, menos complexas e incolores. Dependendo do tempo de contato e da concentração do agente clareador, a efervescência da reação de clareamento acabaria, por arrasto, expulsando o remanescente molecular do pigmento, total ou parcialmente oxidado, para fora do dente.

Tabela 1: Ciclo de decomposição do peróxido de hidrogênio. Observe que o peróxido ao se decompor, passa por uma fase de decomposição intermediária, representada por dois íons hidroxila, antes de transformar-se em água e oxigênio nascente. $\mathrm{O}$ ín hidroxila apresenta potencial de clarear as estruturas dentais, mas o ideal seria que a reação toda se completasse, pois o oxigênio nascente tem maior potencial para tal finalidade.

\begin{tabular}{|c|c|c|c|}
\hline $\begin{array}{l}\text { PERÓXIDO DE } \\
\text { HIDROGÉNIO }\end{array}$ & IONS HIDROXILA & AGUA & $\begin{array}{l}\text { OXIGËNIO } \\
\text { NASCENTE }\end{array}$ \\
\hline
\end{tabular}


CLAREAMENTO CASEIRO: O peróxido de carbamida $(94 \mathrm{~g} / \mathrm{mol})$ sob a forma de um gel ou sol é aplicado sobre o esmalte com o auxílio de uma moldeira; seu pH nesse momento gira em torno de 6,5 (nesse $\mathrm{pH}$ ligeiramente ácido, tal peróxido é mais estável e se conserva por mais tempo), mas rapidamente se eleva para um pico de aproximadamente $9,8^{35}$. Isso favoreceria a decomposição de outras moléculas de peróxido, o que ocorreria em cadeia, já que um pH alcalino desestabiliza ionicamente qualquer peróxido. Desse modo, o peróxido de carbamida decompor-se-ia em peróxido de hidrogênio e uréia (responsável pela alcalinidade). Cientes de que todo peróxido necessita de um "gatilho"\# para iniciar sua decomposição, acreditamos que esse gatilho, nesse caso específico seja a saliva do paciente, ou melhor, as enzimas salivares nela presentes (Tabela 2). Nesse momento, teríamos como agente ativo o peróxido de hidrogênio (Tabela 1), que estaria em contato com dois fatores de degradação de peróxidos: as enzimas salivares e o pH alcalino gerado pela uréia, o que aumentaria ainda mais a eficácia de obtenção de radicais livres, tão necessários para o clareamento.

Em concentração baixa e liberação gradual, os pigmentos são removidos com segurança, formando um óxido solúvel (ou não solúvel), sem qualquer prejuízo para o remanescente dental, pois clareadores de baixo potencial oxidativo gerariam baixas tensões oxidativas e os de alto potencial oxidativo produziriam altas tensões oxidativas, sendo que esta última opção deveria ser utilizada com cautela.

Finalizando esta introdução de capítulo, com a exposição desta hipótese, acreditamos que atualmente 0 estudo dos processos clareadores nas estruturas dentárias tem consumido um considerável tempo de vários pesquisadores e também ocupado um volume cada vez maior nas revistas voltadas para publicações científicas na área odontológica. Grande parte dessas publicações é dirigida quase que exclusivamente à divulgação

\footnotetext{
\# "Gatilhos" são substâncias químicas que desestabilizam os peróxidos, fazendo com que sua decomposição origine o gás oxigênio nascente, principal protagonista das reações clareadoras.
} 
de técnicas clareadoras, de novos produtos, seus resultados clínicos e de várias suposições que relacionam o processo clareador e seus possíveis efeitos colaterais, já que o uso dos peróxidos para a restauração da cor natural, ou para a obtenção de uma cor mais clara em dentes escurecidos ou manchados, é encarada como a mais conservadora arma para a devolução de uma estética mais agradável atualmente disponível.

Tabela 2: Mostra o ciclo de decomposição do peróxido de carbamida, que num primeiro momento origina uréia e peróxido de hidrogênio. Estes, respectivamente por sua vez, decompõe-se em amônia e gás carbônico (uréia) e água e oxigênio nascente (peróxido de hidrogênio).

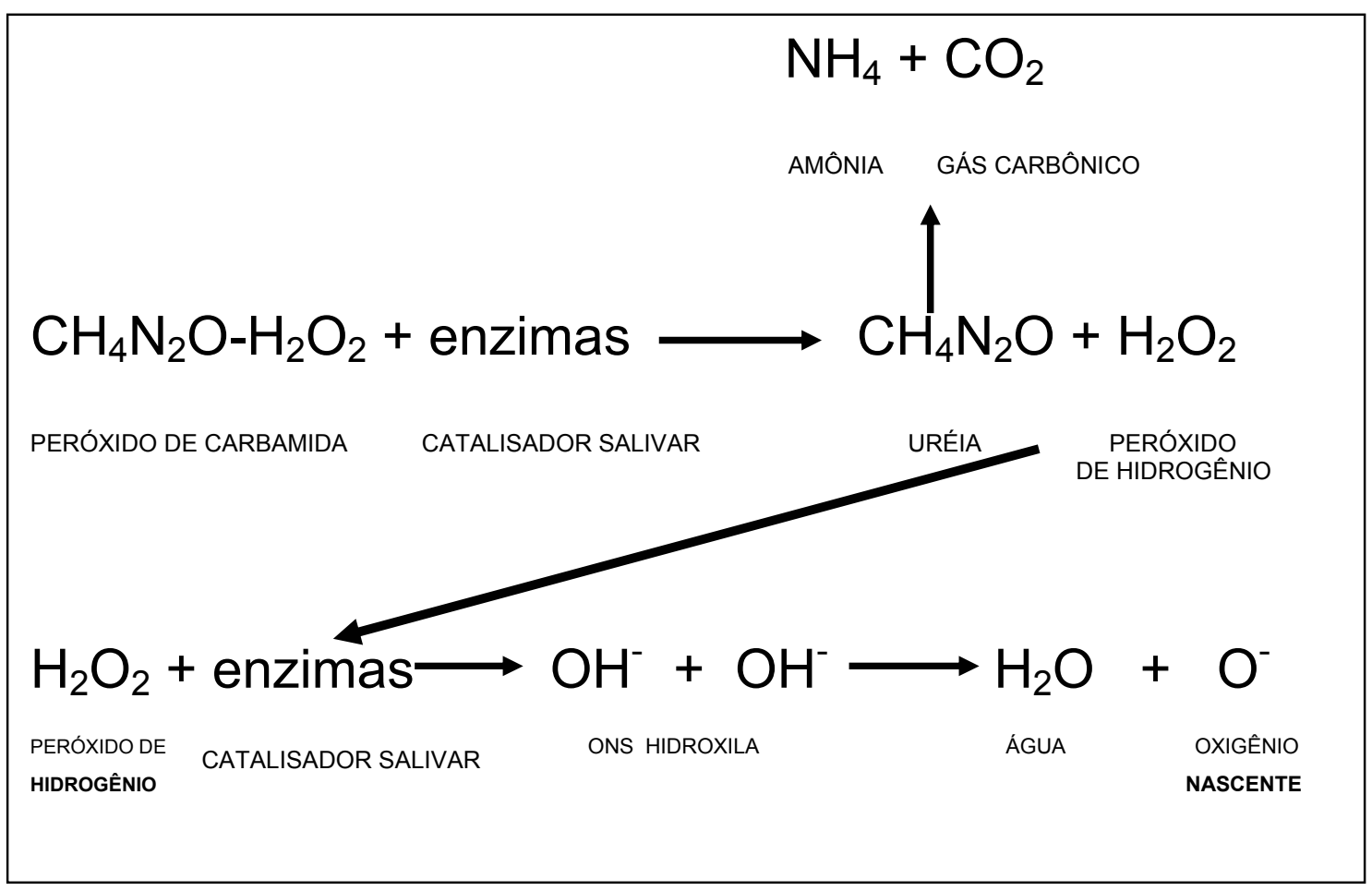

O que motivou este estudo foi a observação clínica de alguns pacientes que, após terem seus dentes submetidos a alguns tipos de tratamentos clareadores, apresentavam uma duradoura aparência "fosca" e "opaca" após algumas semanas de finalizado o tratamento, que se mostrava mais exuberantemente quando seus dentes estavam secos; úmidos, tais dentes não apresentavam esse aspecto. A identificação do peróxido 
envolvido e de um método que pudesse contornar tal efeito colateral passou a ser nosso objetivo, pois um aumento na rugosidade, mesmo que temporário, poderia levar a um ciclo de novo escurecimento pela deposição de pigmentos.

A compreensão dos aspectos físico-químicos que regem as reações de decomposição dos peróxidos poderia servir para uma melhor compreensão dos mecanismos clareadores, que ocorrem no íntimo da estrutura dentária, colaborando para esclarecer se há ou não uma relação entre concentração, tempo de aplicação e potencial de dano no esmalte dental.

\section{2 - Discussão dos métodos empregados}

O uso de dentes bovinos em nosso estudo deveu-se ao fato dos mesmos possuírem boa similaridade histológica com os dentes humanos ${ }^{2,62}$, serem de fácil coleta, sendo encontrados em quantidade e possuírem volume vestibular suficiente, onde se consegue a evidenciação de uma área "plana" extensa para os nossos propósitos.

Durante o preparo dos corpos-de-prova, tornou-se necessário o lixamento da superfície vestibular do esmalte, que ficara exposta. Tal lixamento foi realizado porque a superfície do esmalte bovino apresenta periquimácias extremamente numerosas e profundas, o que impossibilitaria o adequado registro numérico da dureza e da rugosidade com seus respectivos dispositivos de leitura. Após a regularização do esmalte, com lixas de granulação decrescente, obteve-se uma maior uniformidade entre todos os quarenta corpos-de-prova, que ficaram armazenados em água deionizada até o momento dos experimentos já descritos e também nos intervalos entre os respectivos testes. Optamos pela água deionizada, visando prevenir alterações iônicas na superfície do esmalte, como por exemplo, a deposição de algum tipo de sal ou óxido que pudesse prejudicar a real ação dos peróxidos selecionados. 
Um aspecto importante para ser colocado neste momento é o que se refere à decomposição dos peróxidos, já que isto é muito importante, senão fundamental, para que possa ocorrer a reação de clareamento. Os peróxidos são instáveis ${ }^{7}$, mas mesmo com essa suposta instabilidade, existem maneiras de torná-los "menos instáveis" ou "muito mais instáveis" à ponto de provocarmos sua decomposição em seu óxido de origem ${ }^{0}$. Quando mantidos a baixas temperaturas ${ }^{39}$, ao abrigo da luz ${ }^{7,51}$, longe de variações bruscas de $\mathrm{pH}^{51}$, afastado de alguns sais metálicos ${ }^{7,39,51}$ (como os cloretos de ferro, cobre ou alumínio) e sem contato com algumas enzimas salivares ${ }^{51}$, os peróxidos mantêm-se relativamente estáveis; já quando o inverso ocorre, temos a quebra da molécula do peróxido que, no caso do peróxido de hidrogênio, decompõe-se em água e oxigênio nascente ${ }^{51}$.

O grupo do peróxido de hidrogênio a $35 \%$ foi aquecido e irradiado por luz incandescente, promovendo a decomposição da referida molécula de peróxido, como se refere GOLDSTEIN; GARBER ${ }^{19}$, na descrição da técnica de clareamento em ambiente ambulatorial. Em tal técnica, o peróxido citado é irradiado com luz e sua decomposição se dá parte pela luminosidade e parte pelo aquecimento.

O Opalescence X-tra contém em sua composição o caroteno, daí a justificativa da cor alaranjada que o produto apresenta. $O$ grupo tratado por tal produto, logo após a sua aplicação, também foi irradiado por luz de alta intensidade, o que foi possível com a adoção da luz halógena proveniente de um fotopolimerizador empregado para polimerizar resinas compostas. A função da luz halógena é sensibilizar o caroteno ${ }^{51}$, que nada mais é do que um tipo de clorofila, para que o mesmo possa a dissociar-se em duas moléculas mais simples, conhecidas como ácido retinóico, causando um desequilíbrio ${ }^{51}$ no potencial hidrogeniônico deste sol clareador; estudos $^{7,39,50,51}$ relatam que essa brusca alteração de $\mathrm{pH}$ causa um desequilíbrio no peróxido de hidrogênio contido neste referido produto comercial, ocasionando a liberação do oxigênio nascente, que é o íon responsável pelo efeito clareador. O tipo de clorofila empregado no produto 
interfere no resultado final do tratamento, pois existem dois tipos básicos desse pigmento absorvente de luz: um hidrossolúvel, de cor laranja, derivado de vegetais com a cenoura ou beterraba e outro, lipossolúvel, de cor amareloouro, que é derivado de uma planta sul-americana, conhecida como urucum. O Opalescence X-tra possui clorofila hidrossolúvel, o que confere um trânsito mais eficiente dos produtos de reação deste clareador dental. Seguimos em nosso método de aplicação deste produto às instruções do fabricante, que sempre eram revisadas por seus consultores em reuniões periódicas, já que o Opalescence X-tra teve problemas relacionados à sua estabilidade no Brasil, justificadas pela alta temperatura média em nosso país e às condições inadequadas de transporte desde os EUA. Atualmente este produto tem uma embalagem diferenciada para a América do Sul e Oceania, o que diminui sensivelmente os problemas acima descritos.

O método mais trabalhoso e mais interessante de ser elaborado, sem dúvida nenhuma foi aquele que empregou o Opalescence Regular. Esse agente clareador, formulado à base de peróxido de carbamida a $10 \%$, possui ainda glicerina e um altíssimo conteúdo de carboxipolimetileno (conhecido popularmente como carbopol, seu nome fantasia), o que the confere alta viscosidade, baixo escoamento e boa retenção dentro da moldeira. A maioria dos trabalhos consultados neste estudo empregou peróxido de carbamida puro, sem nenhum método de ativação que permitisse sua decomposição adequada, muito embora alguns salientaram a importância da saliva artificial como componente de ativação. É importante ressaltar que, no primeiro caso, o uso de géis ou de sóis de peróxido de carbamida puro pode fazer com que a superfície do esmalte apresente-se apenas desidratada ${ }^{51}$, pois não há nenhum "gatilho" que promova a decomposição do peróxido de carbamida em seus constituintes intermediários, uréia e peróxido de hidrogênio e muito menos em seus produtos finais de reação, que são o oxigênio nascente e a água. O uso da saliva artificial também nos parece contraditório pelo simples motivo de que, nessas formulações não estão incluídas nenhum tipo de enzima, como por exemplo a catalase ou a peroxidase. Pode-se inferir que a saliva artificial não 
oferece um "gatilho" para decompor o peróxido de carbamida, o que nos leva a acreditar que os resultados colhidos nos estudos consultados ${ }^{0}$ deveriam ser revistos com cautela. Em nosso trabalho, a opção de uso de saliva natural misturada com o peróxido de carbamida, procurou refletir uma situação clinicamente verdadeira, com um resultado que vai contra a maioria dos trabalhos consultados; apenas SPALDING ${ }^{58}$ inseriu em seu método de avaliação a saliva natural, muito embora a mesma não estava misturada com o peróxido de carbamida.

O tempo de aplicação do peróxido de carbamida também é um fator importante a ser analisado, pois no trabalho pioneiro de HAYWOOD; HEYMANN ${ }^{24}$, era preconizado que o peróxido de carbamida permanecesse dentro da moldeira pelo tempo de 8 a 12 horas diárias, de preferência no horário de sono, durante um intervalo de 2 a 5 semanas; estudos mais recentes $28,34,41,55,58,59$ indicam uma posologia mais branda, com um tempo de 4 a 6 horas diárias e por períodos de uso de 1 a 3 semanas, sendo desejável, inclusive, que se empregue a moldeira durante o período diurno ${ }^{51}$, pois se o "gatilho" que decompõe o peróxido de carbamida são as enzimas salivares, seria lógico e aconselhável que tal tratamento fosse realizado durante 0 período de vigília e não durante o sono. Durante o sono, segundo RIEHL ${ }^{51}$, poderia ocorrer um "pseudo-clareamento", pois o peróxido não seria adequadamente decomposto pela pouca saliva disponível, o que contribuiria para uma desidratação dos dentes. Isso explicaria clinicamente o aspecto extremamente claro dos dentes de alguns pacientes que se submeteram ao tratamento noturno e que, depois de finalizado tal tratamento, reclamaram que seus dentes "escureceram um pouco"; podemos suspeitar de que, na verdade, houve uma reidratação e não uma recidiva.

É interessante relatar que nos intervalos entre as sessões de clareamento de todos os grupos, os espécimes ficaram armazenados em saliva artificial, especificamente formulada para remineralização (sem enzimas), mais uma vez valorizando o que ocorre realmente durante um tratamento clareador. 
Conforme descrição no capítulo Materiais e Métodos e também no que descreve os Resultados, "Ficou previamente estabelecido que, se houvesse diferença visível nos valores de dureza e de rugosidade, comparando-se a média aritmética inicial e final de cada grupo, os grupos com alteração, ou seja, uma suposta queda na dureza média e aumento de rugosidade, uma tentativa de recuperação da dureza e da rugosidade originais seria tentada através da adoção de uma única sessão de microabrasão, executada com o produto Opalustre", tal diferença foi percebida e detectada, motivo pelo qual, uma única sessão de ameloplastia ácida foi executada, de acordo com o método descrito no resumo do trabalho de MENDES ${ }^{44}$ e corroborado por vários outros trabalhos ${ }^{9-13,59,65}$.

Os testes que determinaram os valores numéricos da rugosidade e da dureza foram executados segundo o protocolo descrito no capítulo Materiais e Métodos, e obedeceram as regras e determinações técnicas que acompanham as respectivas máquinas de ensaio, "softwares" e tabelas de conversão, já que um mesmo ensaio pode ser executado de maneiras ligeiramente diferentes, bastando para isso que equipamentos diferentes sejam empregados.

\section{3 - Discussão dos resultados obtidos}

Após a execução dos tratamentos clareadores já descritos, todos os grupos apresentaram alterações de cor bastante perceptíveis, com exceção do grupo controle, o que vai de encontro com os resultados de diversos estudos ${ }^{24,28,30,34,49,51}$, que relatam a diminuição do croma ${ }^{40}$ e mesmo do valor. Todos os agentes clareadores realmente, com maior ou menor rapidez, promoveram uma diminuição no valor colorimétrico dos dentes incluídos nos corpo-de-prova, inclusive da porção inclusa na resina epóxica, o que comprova a alta difusibilidade dos peróxidos ${ }^{26,57}$. Os efeitos dos agentes clareadores na estrutura dentária têm sido relatados, mostrando que eles podem alterar a microdureza do esmalte ${ }^{2,37,45,47,62,66}$, sua rugosidade ${ }^{9-}$ $13,14,26,27,34,54,56,65$, composição química ${ }^{16,52,53}$ e a força de adesão dos 
sistemas adesivos e resinas compostas ao esmalte recém-clareado ${ }^{29,45,55,63-}$ 65. Entretanto, a maioria dos trabalhos que apresentam alterações nessas propriedades supracitadas, após a aplicação de agentes clareadores, muitas vezes trazem problemas metodológicos na sua realização e planejamento, e em sua grande maioria há uma deficiência nos critérios empregados para a avaliação de possíveis alterações. Os dados referentes às alterações morfológicas na estrutura do esmalte são conflitantes, em função da enorme variedade de métodos utilizados nos estudos, bem como na influência da diversidade de produtos, concentrações, $\mathrm{pH}$, orientações técnicas e marcas comerciais analisadas $3,4,7,21,58,60,62,65,68$. Dessa maneira, torna-se extremamente difícil encontrar dados confiáveis e seguros, colocados com critérios e com embasamento biológico e químico para se comparar resultados. Conjuntamente a essas dificuldades, a maioria dos trabalhos que se referem ao aspecto morfológico da superfície dental clareada não especifica os critérios empregados para a comparação dos espécimes $^{3,4,7,16,21,62}$, não leva em consideração as diferenças ultraestruturais dos dentes ${ }^{3,4,7,16}$, empregam como grupos-controle fragmentos de dentes diferentes ${ }^{3,4,729,43,65,68}$ e por muitas vezes não especificam os dados contidos na embalagem ou na bula do produto pesquisado ${ }^{3}$.

Tentando contornar essas limitações na escolha e execução dos métodos selecionados (que já foram discutidos), obtivemos resultados que podem ser divididos em duas partes para melhor análise e compreensão: 1) efeitos decorrentes da ação do peróxido de carbamida e 2) efeitos decorrentes da ação do peróxido de hidrogênio a 35\% e do Opalescence Xtra.

Nos ensaios de dureza, o peróxido de carbamida a 10\% não promoveu alterações estatisticamente significantes entre o grupo controle e o grupo tratado, como podem atestar desde o início, as tabelas referentes à média, à análise de variância e o teste de Tukey. Isso vai de encontro com os achados de HAYWOOD et al. ${ }^{26}$ e MURCHINSON; CHARLTON; MOORE ${ }^{45}$, que empregaram saliva artificial em seus trabalhos, mas diverge 
completamente do que relataram LEWISTEIN et al. $^{37}$, PÉCORA et al. ${ }^{47}$, ATTIN et al. ${ }^{2}$, que empregaram peróxidos puros (sem "gatilhos de decomposição"), o que dificulta o entendimento e a comparação desses resultados com outros, principalmente levando-se em conta os aspectos já discutidos do ponto de vista bioquímico, como o do "pseudo-clareamento" e da desidratação causada pelos componentes de tal produto; como fator agravante, muitos responsabilizavam as alterações superficiais no esmalte aos componentes ácidos presentes nos mesmos, pois os clareadores da época continham quantidades traço de ácido fosfórico, maleico ou cítrico em sua composição com a finalidade de aumentar sua estabilidade. Essa quantidade traço de ácido estaria associada a uma possível desmineralização, o que não parecia ocorrer, porque o peróxido de carbamida tem seu $\mathrm{pH}$ elevado à medida que se decompõe $\mathrm{e}^{35,36,50,51}$, principalmente pela formação intermediária de uréia. Esses resultados nos dão credibilidade para ousar afirmar que, teoricamente, por possuir uma baixa potência oxidativa e, conseqüentemente, submeter o esmalte a uma pequena tensão oxidativa desde que corretamente aplicado, o peróxido de carbamida a 10\% não é capaz de desnaturar a porção orgânica do esmalte $^{53,56,61}$, pois suspeita-se de sua remoção quando se submete o esmalte a altas tensões oxidativas. Em nosso trabalho tivemos o cuidado de manter todos os corpos-de-prova imersos em saliva artificial nos períodos em que não estavam em tratamento clareador; tal motivo originou-se da preocupação em promover a remineralização do esmalte caso houvesse realmente desmineralização do esmalte clareado, mas, nos grupos que originaram alto potencial oxidativo, poderíamos acreditar que como a porção orgânica não é passível de remineralização pelos íons salivares, o efeito nocivo do clareamento caseiro nesses grupos foi notado, pois supostamente não houve somente perda mineral, mas sim uma grande perda orgânica, que não é reposta pela abundância de íons contidos na saliva artificial ${ }^{29,51}$.

O peróxido de hidrogênio e o Opalescence X-tra mostraram um comportamento oposto ao grupo do peróxido de carbamida a $10 \%$, já com evidências de grande diferença em relação ao grupo controle ao se comparar 
primariamente às médias; a análise de variância, complementada pelo teste de Tukey e um teste "t" pareado, deixou claro haver diferença significante para $p<0,05$ nos grupos do peróxido de hidrogênio e Opalescence $X$-tra, o que sustenta a hipótese de que clareadores com elevada potência oxidativa podem realmente provocar um nítido estresse oxidativo, ou seja, os clareadores mais concentrados poderiam provocar um dano no esmalte, evidenciado pela diminuição nos valores da dureza Vickers e pelo aumento da rugosidade, efeitos estes observados em nosso trabalho, e que poderiam favorecer, segundo RIEHL ${ }^{51}$, o estabelecimento de regiões onde a placa bacteriana e novos pigmentos se instalariam com mais facilidade, promovendo um "novo escurecimento" dos dentes clareados por essas técnicas, o que comumente é conhecido como recidiva.

Nos grupos clareados com o peróxido de hidrogênio a 35\% e Opalescence X-tra, devido à diminuição nos valores da dureza Vickers e ao aumento da rugosidade do esmalte, devidamente já demonstrados e discutidos, optou-se por tentar reverter tal efeito negativo aplicando uma pasta ácida para que eliminássemos a camada mais superficial de esmalte, teoricamente afetada pela alta tensão oxidativa, pois a mesma apresentavase menos dura e, com a exposição de uma nova superfície, poderíamos conseguir a reversão dessa situação. Os procedimentos de microabrasão ou ameloplastia foram executados de acordo com o método empregado por MENDES $^{44}$, e descrito na literatura por vários autores, onde se destacam CROLL $^{9-13}$ e SUNDFELD ${ }^{59}$, grandes pesquisadores da área. Após tal tratamento, e frente aos novos dados, nova análise estatística foi efetuada e os resultados da análise de variância para comparação entre os quatro grupos, levando em conta as diferenças entre as fases final e inicial para os grupos tratados com água deionizada e Opalescence Regular e as diferenças entre as fases ameloplastia e inicial para as os grupos clareados com o peróxido de hidrogênio a 35\% e Opalescence X-tra, mostrou não haver diferença estatisticamente significante. Estes resultados parecem levar à possível conclusão de que, após uma sessão de clareamento de consultório, com agentes clareadores de alto potencial oxidativo, poder-se-ia sugerir a 
adoção de uma aplicação da técnica de ameloplastia para devolução de uma superfície de esmalte mais dura, à semelhança do esmalte hígido.

Quanto à propriedade rugosidade, os resultados colhidos do grupo tratado com peróxido de carbamida a 10\% não possuem diferença estatisticamente significante em relação ao grupo controle, como demonstraram as médias, a análise de variância e o teste de Tuckey. Para os grupos clareados com peróxido de hidrogênio a 35\% e Opalescence X-tra, houve diferenças estatisticamente significantes, à semelhança do que ocorreu durante o estudo da propriedade dureza Vickers.

De encontro aos achados relacionados com o aumento de rugosidade, convergem diversos autores ${ }^{3,4,30,43,54,56,60,65}$, muito embora comparar seus métodos de avaliação é tarefa difícil, pelo o que já foi colocado no início deste capítulo. Entretanto, podemos listar algumas justificativas apresentadas para a ocorrência do aumento de porosidade de rugosidade na superfície do esmalte: 1) condicionamento ácido ${ }^{4,30,43,65}$ previamente ao tratamento clareador, visando aumentar a permeabilidade do esmalte ao peróxido ou ao oxigênio nascente; 2) $\mathrm{pH}$ inicial do agente clareador muito baixo ${ }^{54,56}$, o que atuaria já como um condicionamento ácido e 3) ausência de um gatilho de decomposição ${ }^{4,60}$ faria com que o efeito de desidratação pudesse ser responsabilizado por tais efeitos de aumento de rugosidade e de permeabilidade. Um dos únicos estudos que não apresentaram efeitos de aumento de rugosidade foi o de GULTZ et al. ${ }^{21}$, cujo método levou em conta a aplicação de saliva artificial.

O condicionamento ácido aplicado previamente ao tratamento clareador ou seu $\mathrm{pH}$ muito baixo, realmente parecem colaborar para o aumento e a manutenção das irregularidades na superfície do esmalte ${ }^{30,56}$, principalmente se o fabricante do agente clareador preconiza a aplicação de enxaguantes bucais contendo ácido cítrico e fosfórico antes de usá-lo ${ }^{4}$. MCCRACKEN; HAYWOOD ${ }^{41}$, relataram um interessante dado, ao relacionar a perda de cálcio do esmalte durante o tratamento clareador, comparando-o à 
ingestão de refrigerantes. Seus resultados apontam para que não houve diferença estatisticamente significante entre a quantidade de cálcio pedida dos dentes imersos por 2,5 minutos em refrigerantes e os dentes tratados com peróxido de carbamida a $10 \%$, sugerindo afirmar que, embora existissem alterações ocorridas na superfície adamantina após a aplicação do produto clareador, seu significado clínico deva ser re-examinado, visto que quantidades similares de cálcio são perdidas com a exposição do dente a refrigerante por 2,5 minutos.

Os atuais produtos clareadores à base de peróxido de carbamida possuem $\mathrm{pH}$ próximo ao neutro ${ }^{48}$, o que os coloca em situação privilegiada em relação a uma possível ação pré-condicionadora do esmalte.

Convém salientar a grande importância de termos um gatilho de decomposição inserido no método escolhido para a execução do trabalho, pois sem a real decomposição do peróxido, fica extremamente difícil creditar ou não tais aspectos de aumento de rugosidade e porosidade somente ao tratamento clareador como lembrou $\mathrm{RIEHL}^{50}$ ao criticar o trabalho de TAMES;GRANDO;TAMES ${ }^{60}$.

Ao ficar evidente a diferença significativa entre grupos tratados com peróxido de hidrogênio a 35\% e Opalescence X-tra, foi feita uma tentativa de recuperação da lisura da superfície do esmalte através da técnica de ameloplastia já descrita. Nova análise de variância foi feita e ainda detectou diferença estatisticamente significante. O teste de Tukey mostrou não haver diferenças entre o grupo controle e o peróxido de carbamida a $10 \%$, mas indicou diferença entre os grupos peróxido de hidrogênio e Opalescence X-tra. Para as condições peróxido de hidrogênio e Opalescence X-tra foi feita a comparação entre a fase final e ameloplastia, por meio do teste "t" pareado e este mostrou diferença estatisticamente significante nesses grupos, o que parece significar que apenas uma sessão de microabrasão foi capaz de restaurar a lisura original que apresentava um dente hígido. 
Ao final deste capítulo, gostaríamos de lembrar que nossa opinião fundamentou-se basicamente na química, na bioquímica, na literatura consultada e na experiência clínica acumulada nos anos de prática. Parafraseando SPALDING ${ }^{58}$, que concluiu sua dissertação de mestrado escrevendo que, "na análise comparativa do efeito dos materiais clareadores na superfície do esmalte dental humano existe uma grande variação no padrão morfológico normal do esmalte; áreas alteradas observadas em alguns espécimes experimentais tratados com peróxido de carbamida e peróxido de hidrogênio foram discretas, e que os materiais clareadores não provocaram um efeito característico peculiar. Concluiu ainda que os materiais testados conforme estabelecido neste estudo não trazem grandes implicações clínicas e que estudos adicionais avaliando outras propriedades do esmalte, após a utilização de materiais clareadores, tornam-se necessários".

Clareamento é um exercício de paciência, que requer treino e estudo individual de cada caso, de cada paciente, de cada situação.

A determinação dos valores de tensão oxidativa das diversas substâncias clareadoras poderá nortear, em casos de clareamento, a escolha de materiais que se comportem de maneira mais inócua, ou menos agressiva, quando em contato com os tecidos dentários, contribuindo de maneira já preventiva na manutenção da estética recuperada.

Nossa luta em busca de tratamentos estéticos cada vez mais efetivos e seguros continua na direção da verdade científica, dos pensamentos e atitudes não tendenciosos e com o objetivo primordial de contribuir para o engrandecimento da Odontologia como um todo.

Por isso acreditamos no clareamento dental como uma ciência, indicando-o com a opção mais conservadora para a obtenção de uma estética dental mais atraente, pois acreditamos que o bom senso 
durante o processo diagnóstico e o conhecimento da potência dos peróxidos envolvidos é o caminho seguro para um bom resultado. 
7 - Conclusões 


\section{7 - CONCLUSÕES}

Com base na proposição e na análise estatística dos dados apresentados, em relação às propriedades estudadas, pode-se concluir que:

1) Os tratamentos clareadores realizados com o peróxido de hidrogênio a $35 \%$ e com o Opalescence X-tra provocaram alterações no esmalte bovino, sendo estas mais intensas no grupo do peróxido de hidrogênio a $35 \%$;

2) O tratamento com peróxido de carbamida a $10 \%$ (Opalescence Regular) não promoveu nenhuma alteração significante no substrato estudado;

3) Nos casos de ocorrência de alteração no esmalte, o tratamento proposto com Opalustre (ameloplastia ácida) foi capaz de recuperar os valores iniciais de rugosidade e dureza;

4) Parece haver uma correlação entre concentração, tempo de aplicação e potencial de dano no esmalte, quando se trabalha com peróxidos. 
Referências bibliográficas 


\section{REFERÊNCIAS BIBLIOGRÁFICAS}

1 - AMES, J.W. Removing stains from mottled enamel. J. Amer. dent. Ass. I Dent. Cosmos, p.1674-7, 1937.

2 - ATTIN, T. et al. Effect of fluoride treatment on remineralization of bleached enamel. J. oral Rehab., v. 24, n. 4, p. 282-6, April, 1997.

3 - BEN-AMAR, A. et al. Effect of mouthguard bleaching on enamel surface. Amer. J. Dent., v. 8, n. 1, p. 29-32, Feb. 1995.

4 - BITTER, N.C. A scanning electron microscope study of the long-term effect of bleaching agents on the enamel surface "in vivo". Gen. Dent., v. 46, n. 1, p. 84-8, Jan/Feb., 1998.

5 - BOGUE, E.A. Bleaching Teeth. Dent. Cosmos, v.14, p.1-3, 1872.

6 - BOWLES, W.H.; UGWUNERI, Z. Pulp chamber penetration by hydrogen peroxide following vital bleaching procedures. J. Endod., v. 13, n. 8, p. 375-7, Aug. 1987.

7 - CHEN, J.H. et al. Decomposition rate of hydrogen peroxide bleaching agents under various chemical and physical conditions. J. prosth. Dent., v.69, n.1, p.46-8, 1993.

8 - CREWS, K.M. et al. Effect of bleaching agents on chemical composition of enamel. Miss. Dent. Assoc. J. , v. 53, n.1, p. 20-1, Spring, 1997.

9 - CROLL, T.P.; CAVAUNAGH, R.R. Enamel color modification by controlled hydrochloric acid-pumice abrasion. I. Technique and examples. Quintessence Int., v. 17, n. 2, p. 81-7, Feb. 1986.

10 - CROLL, T.P.; CAVAUNAGH, R.R. Enamel color modification by controlled hydrochloric acid-pumice abrasion. II. Further examples. Quintessence Int., v. 17, n. 3, p. 157-64, Mar. 1986.

11- CROLL, T.P. Enamel color improvement: all things considered. Quintessence Int., v. 17, n. 5, p. 271-5, May 1986. 
12- CROLL, T.P. Enamel microabrasion followed by dental bleaching: cases reports. Quintessence Int., v. 23, n. 5, p. 317-21, May, 1992.

13- CROLL, T.P. Enamel microabrasion: observations after 10 years. J Amer. dent. Ass. , v. 128, p. 45S-50S, Apr. 1997. Special issue.

14- CVITKO, E.; SWIFT, E.J.; DENEHY, G.E. Improved esthetics with a combined bleaching technique: a case report. Quintessence Int., v. 23, n. 2, p. 91-3, Feb. 1992.

15- DWINELLE W.W. Ninth Annual Meeting of American Society of Dental Surgeons. Article X. Am. J. Dent. Sci. v.1, p.57-61, 1850.

16- ERNST, C.P.; MARROQUÍN, B.B.; ZONNCHEN, B.W. Effects of hydrogen peroxide-containing bleaching agents on the morphology of human enamel. Quintessence Int., v. 27, n.1, p.53-6, Jan. 1996.

17- FISCHER, G. The bleaching of discolored teeth with $\mathrm{H}_{2} \mathrm{O}_{2}$. Dent. Cosmos, v.53, p.246-7, 1911.

18- FLOYD, R.A. The effect of peroxides and free radicals on body tissues. JADA, v.128, p. 37S-40S, April 1997.

19- GOLDSTEIN, R.E.; GARBER, D.A. Complete dental bleaching. Chicago, Quintessence Publishing, 1995 165p.

20- GONÇALVES, F.C.; MONTE ALTO, L.A.; RAMOS, M.A.B. Alteração cromática e morfológica do esmalte dental após tratamento com peróxido de carbamida a 10\%. J Bras Clin Odontol Int, Curitiba, v.5, n.29, p.413-17, Set/Out, 2001.

21- GULTZ, J. et al. Two In-Office bleaching systems: a scanning electron microscope study. Comp. Continuing Educ. Dent., v. 20, n. 10, p. 965-72, Oct. 1999.

22- HARLAN, A.W. The dental pulp, its destruction, and methods of treatment of teeth discolored by its retention in the pulp chamber or canals. Dent. Cosmos, v.33, p.137-41, 1891.

23- HARLAN, A.W. Proceeding of the American Dental Associotion -Twenty Third Annual Session. Dent. Cosmos, v. 26, p.97-8, 1884. 
24- HAYWOOD, V.B.; HEYMANN, H.O. Nightguard vital bleaching. Quintessence Int., v.20, n.3, p.173-6, Mar. 1989.

25- HAYWOOD, V.B. History, safety and effectiveness of bleaching techniques and applications of the nightguard vital bleaching technique. Quintessence. Int., v.23, n.7, p. 471-88, Jul. 1992.

26- HAYWOOD, V.B.; HOUCK, V.M.; HEYMAN, H.O. Nightguard vital bleaching: effects on enamel surface texture and diffusion. Quintessence Int., v. 21, n. 10, p. 801-4, Oct. 1990.

27- HAYWOOD, V.B. et al. Nightguard vital bleaching: effects of various solutions on enamel surface texture and color. Quintessence Int., v.22, n. 10, p. 775-82, Oct. 1991.

28- HAYWOOD, V.B. et al. Effectiveness side effects and long-term status of nightguard vital bleaching. J. Amer. dent. Ass., v. 125, n. 9, p. 121926, Sept. 1994.

29- JOSEY, A.L. et al. The effect of a vital bleaching technique on enamel surface morphology and the bonding of composite resin to enamel. J. oral Rehab., n.4, p. 244-50, Apr. 1996.

30- JUNQUEIRA, J.C. et al. Efeito da técnica de clareamento, utilizando peróxido de carbamida a 35\%, sobre esmalte dental - Avaliação por microscopia de luz polarizada e microscopia eletrônica de varredura. JBC, vol. 4, n. 24, Nov/Dez, 2000.

31- KINGSBURY, C.A. Discoloration of dentine. Dent. Cosmos, v.3, p.60, 1861.

32- KIRK E.C. Hints, queries, and comments: sodium peroxide. Dent. Cosmos, v.35, p.1265-7, 1893.

33- KIRK, E.C. The chemical bleaching of teeth. Dent. Cosmos, v.31, p.273, 1889.

34- LEE, C. et al. Effect of bleaching on microhardness, morphology and color enamel. Gen.Dent., vol.43, n.2, p.158-62, 1995.

35- LEONARD JUNIOR, R.H; BENTLEY, C.D.; HAYWOOD, V.B. Salivary $\mathrm{pH}$ changes during $10 \%$ carbamide peroxide bleaching. Quintessence Int., v.25, n.8, p.547-50, Aug. 1994. 
36- LEONARD JUNIOR, R.H. et al. Change in $\mathrm{pH}$ of plaque and $10 \%$ carbamide peroxide solution during nightguard vital bleaching treatment. Quintessence Int., v.25, n.12, p.819-23, Dec. 1994.

37- LEWINSTEIN, I. et al. Effect of hydrogen peroxide and sodium perborate on the microhardness of human enamel and dentin. J. Endod., v. 20, n. 2, p. 61-3, Feb. 1994.

38- LORENZO, J.A. et al. Clinical study of a halogen light-activated bleaching agent in nonvital teeth: case reports. Quintessence Int., v.27, n.6, p. 383-8, June 1996.

39- LU, X.L. The chemistry of inorganic peroxide compounds. Beijing:Science and Technology Publication House. p.65-112, 1987. apud CHEN, J.H. et al. ${ }^{8}$, p.46-48.

40- McASLIN et al. Avaliação de alterações de cor da dentina no clareamento vital com moldeira noturna. JADA Brasil, v.2, n.6, p.59-64, 1999.

41- McCRACKEN, M.S.; HAYWWOD, V.B. Demineralization effects of $10 \%$ carbamida peroxide. J. Dent., v. 24, n.6, p.395-8, Nov. 1996.

42- McEVOY, S.A. Chemical agents for removing intrinsic stains from vital teeth. II. Current techniques and their clinical application. Quintessence Int., v.20, n.6, p.379-84, Jun. 1989.

43- McGUCKIN, R.S.; BABIN, J.F.; MEYER, B. J. Alteration in human enamel surface morphology following vital bleaching. J. prosth. Dent., v. 68, n. 5, p. 754-60, Nov. 1992.

44- MENDES, R.F. Avaliação da quantidade de desgaste, da textura e da morfologia do esmalte dentário submetido à técnica de microabrasão. Bauru, 1999, 163p. Tese (Doutorado) - Universidade de São Paulo.

45- MURCHINSON, D.F.; CHARLTON, D.G., MOORE, B.K. Carbamide peroxide bleaching: effects on enamel surface hardness and bonding. Oper. Dent., v. 15, n. 5, p. 181-5, Sept-Oct. 1992.

46- PASHLEY, D.H.; LIVINGSTON, M.J. Effect of molecular size on permeability coefficients in human dentine. Arch Oral Biol., v.23, p.391-5, 1978. 
47- PÉCORA, J.D. et al. "In vitro" action of various bleaching agents on the microhardness of human dentin. Braz. Dent. J., v. 5, n. 2, p. 129-34, 1994.

48- RIEHL, H. Determinação da variação do pH de várias substâncias usadas intracoronariamente para a restauração da cor (clareamento) da coroa dentária. Bauru, 1998. 110 p. Dissertação (Mestrado) - Universidade de São Paulo.

49- RIEHL, H. A cor da vaidade. Rev. Assoc. Bras. Odontol., v. 6, n. 1, p. 711, 1998.

50- RIEHL, H. Seção Discordando. Rev. Ass. Paul. Cirurg. Dent., v. 52, n. 3, p. 195, Mai/Jun, 1998.

51- RIEHL, H. Clareamento dental. Londrina, CIAPEC on line, 2001. / Em Cd-rom/-programa da aula também disponível na internet: http://www.ciapec.com.br/internas/curso/curso_mod.asp?Curso=11\&T ipo_Curso=2\&modulo=1.

52- ROTSTEIN, I.; LEHR, Z.; GEDALIA, I. Effect of bleaching agents on inorganic components of human dentin and cementum. J. Endod., v.18, n.6, p.290-3, Jun. 1992.

53- ROTSTEIN, I. et al. Histochemical analysis of dental hard tissues following bleaching. J Endod., v. 22, n. 1, p. 23-6, Jan 1996.

54- SHANNON, $H$. et al. Characterization of enamel exposed to $10 \%$ carbamide peroxide. Quintessence Int., v. 125, n. 10, p. 1330-5, Oct. 1994.

55- SILVA E SOUZA, P.A.R. Estudo “in vitro” da infiltração marginal em dentes submetidos a diferentes técnicas de clareamento e restaurados com um sistema adesivo/resina composta. Bauru, 1999, 132p. Dissertação (Mestrado)- Universidade de São Paulo.

56- SOUZA, M.A.L.; BERGAMASCHI, M.A.B.; SOUZA, F.L. Acid etching in bleached enamel. Braz. Endod. J., v.1, n.1, p. 35-8, 1996.

57- SOUZA, M. A. L. Clareamento caseiro de dentes: ação do peróxido de carbamida sobre dentes e mucosa bucal. Porto Alegre, 1993. 234p. Tese (Doutorado) - Pontifícia Universidade Católica do Rio Grande do Sul. 
58- SPALDING, M. Estudo “in vitro" do aspecto morfológico da superfície do esmalte e alteração na permeabilidade dentária após clareação. Bauru, 2000, 137p. Dissertação (Mestrado) Universidade de São Paulo.

59- SUNDFELD, R.H. et al. Recuperação estética do sorriso. Uma conquista promissora no campo da odontologia estética. Rev. Bras. Odontol., v.54, n.6, p.321-5, 1997.

60- TAMES, D.; GRANDO, L.J.; TAMES, D.R. Alterações do esmalte dental submetido ao tratamento com peróxido de carbamida 10\%. Rev. Ass.

Paul. Cirurg. Dent., v. 52, n. 2, p. 145-9, Mar/Abr, 1998.

61- TEN CATE, A.R. Histologia Bucal - Desenvolvimento, Estrutura e

Função. 2.ed. Rio de Janeiro, Editora Guanabara S.A., 1988.

62- TITLEY, K.C.; TORNECK; C.D.; SMITH, D. The effect of concentrated hydrogen peroxide solutions on the surface morphology of human tooth enamel. J.Endod., v. 14, n. 2, p. 69-74, Feb. 1988.

63- TITLEY, K.C.; TORNECK; C.D.; RUSE, N.D. The effect of carbamideperoxide gel on the shear bond strength of a microfill resin to bovine enamel. J. dent. Res., v. 71, n. 1, p. 20-4, Jan. 1992.

64- TITLEY, K.C. et al. Adhesion of a resin composite to bleached and unbleached human enamel. J Endod., v. 72, n.1, p.67-71, Jan. 1993.

65- TONG, L.S.M. et al. The effects of etching, microabrasion, and bleaching on surface enamel. J. dent. Res. V. 72, n. 1, p. 67-71, Jan. 1993.

66- WANG, J.D.; HUME, W.R. Diffusion of hydrogen ion and hidroxyl ion from various sources through dentine. Int. Endod. J., v.21, p.17-26, 1988.

67- WESTLAKE, A. Bleaching teeth by eletricity. Int. Dent. J., v.1, Apr. 1895.

68- ZALKIND, M. et al. Surface morphology changes in human enamel, dentin and cementum following bleaching: a scanning electron microscopy study. Endod. dent. Traumat., v. 12, n. 2, p. 82-88, Apr. 1996. 


\section{Abstract}


ABSTRACT

The influence of 3 whitenning agents upon rugosity and Vickers hardness of bovine dental enamel was evaluated. It were used 40 lower central incisives, divided into 4 groups: $1^{\text {st }}$ ) deionized water, $\left.2^{\text {nd }}\right) 35 \%$ hidrogen peroxide, $3^{\text {rd }}$ ) Opalescence $X$-tra and $4^{\text {th }}$ ) Opalescence Regular $10 \%$. Essays were performed before and after treatments. The inicial and final average values to rugosity (im micrometers) were respectively 58,4 and 58,9 to the teeth from the first group, 62,9 and 399,6 to these of the second, 60,5 and 282,1 to these of the third and 56,4 and 58,5 to these of the fourth; to the hardness (as pure numbers) they were respectively 259,2 and 258,9 to the teeth of the first group, 256,7 and 172,8 to these of the second, 259,7 and 213,1 to these of the third and 260,3 and 259,4 to these of the fourth. It was statiscally detected changes in the specimens of groups 2 and 3 ; due to this, an adittional treatment, named ameloplasty with acid, promoted a recuperation of original values, to both the studied characteristics. 